\title{
Measurements of Worldwide Radioxenon Backgrounds - The "EU" Project
}

TW Bowyer, M Cooper, JC Hayes, J Forrester, D Haas, R Hansen, P. Keller, R Kirkham, L Lidey, JI Mclntyre, HS Miley, R Payne, P Saey ${ }^{1}$, RC Thompson, R Williams, V Woods

September 2009

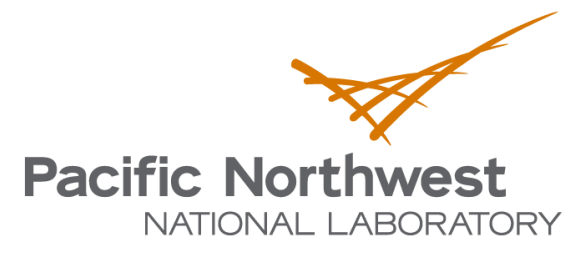

${ }^{1}$ Consultant from the Vienna University of Technology, Atomic Institưfe of theparusertany Baftelle 


\title{
DISCLAIMER
}

This report was prepared as an account of work sponsored by an agency of the United States Government. Neither the United States Government nor any agency thereof, nor Battelle Memorial Institute, nor any of their employees, makes any warranty, express or implied, or assumes any legal liability or responsibility for the accuracy, completeness, or usefulness of any information, apparatus, product, or process disclosed, or represents that its use would not infringe privately owned rights. Reference herein to any specific commercial product, process, or service by trade name, trademark, manufacturer, or otherwise does not necessarily constitute or imply its endorsement, recommendation, or favoring by the United States Government or any agency thereof, or Battelle Memorial Institute. The views and opinions of authors expressed herein do not necessarily state or reflect those of the United States Government or any agency thereof.

\author{
PACIFIC NORTHWEST NATIONAL LABORATORY \\ operated by \\ BATTELLE \\ for the \\ UNITED STATES DEPARTMENT OF ENERGY \\ under Contract DE-AC05-76RL01830
}

Printed in the United States of America

Available to DOE and DOE contractors from the

Office of Scientific and Technical Information,

P.O. Box 62, Oak Ridge, TN 37831-0062;

ph: (865) 576-8401

fax: (865) 576-5728

email: reports@adonis.osti.gov

\author{
Available to the public from the National Technical Information Service, \\ U.S. Department of Commerce, 5285 Port Royal Rd., Springfield, VA 22161 \\ ph: (800) 553-6847 \\ fax: (703) 605-6900 \\ email: orders@ntis.fedworld.gov \\ online ordering: http://www.ntis.gov/ordering.htm
}

This document was printed on recycled paper. 
PNNL-18783

\section{Measurements of Worldwide Radioxenon Backgrounds - The "EU” Project}

TW Bowyer, M Cooper, JC Hayes, J Forrester, D Haas, R Hansen, P. Keller, R Kirkham, L Lidey, JI McIntyre, HS Miley, R Payne P Saey*, RC Thompson, R Williams, V Woods

September 2009

Prepared for

the U.S. Department of Defense, Army Space \& Missile Defense Command

and

the U.S. Department of Energy under Contract DE-AC05-76RL01830

Pacific Northwest National Laboratory

Richland, Washington 99352

\footnotetext{
* Consultant from the Vienna University of Technology, Atomic Institute of the Austrian Universities
} 



\section{Summary}

Under the Comprehensive Nuclear-Test-Ban Treaty (CTBT), radioactive xenon (radioxenon) measurements are one of the principle techniques used to detect nuclear underground nuclear explosions, and specifically, the presence of one or more radioxenon isotopes allows one to determine whether a suspected event was a nuclear explosion or originated from an innocent source.

During the design of the International Monitoring System (IMS), which was designed as the verification mechanism for the Treaty, it was determined that radioxenon measurements should be performed at 40 or more stations worldwide. At the time of the design of the IMS, however, very few details about the background of the xenon isotopes was known and it is now recognized that the backgrounds were probably evolving anyhow.

This paper lays out the beginning of a study of the worldwide concentrations of xenon isotopes that can be used to detect nuclear explosions and several sources that also release radioxenons, and will have to be accounted for during analysis of atmospheric levels. Although the global concentrations of the xenon isotopes are the scope of a much larger activity that could span over several years, this study measures radioxenon concentrations in locations where there was either very little information or there was a unique opportunity to learn more about emissions from known sources. The locations where radioxenon levels were measured and reported here are:

- Belgium,

- Germany,

- Kuwait,

- Thailand, and

- South Africa (Two locations).

In addition, two additional locations in Oman and Nepal were visited for possible inclusion in future measurement campaigns. 



\section{Contents}

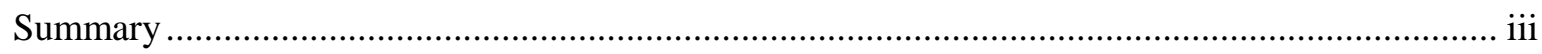

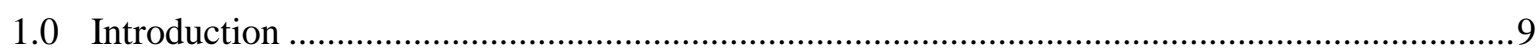

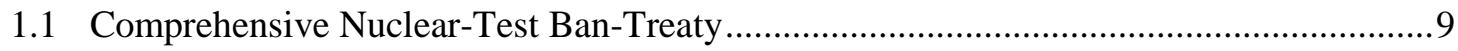

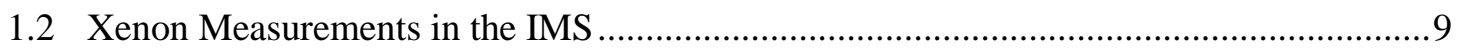

1.3 Worldwide Noble Gas Background ....................................................................... 10

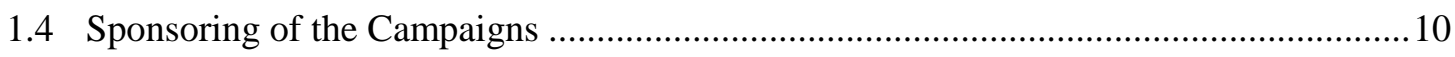

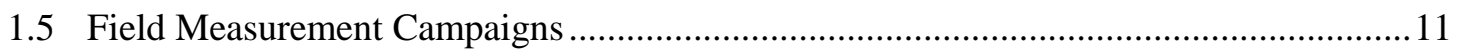

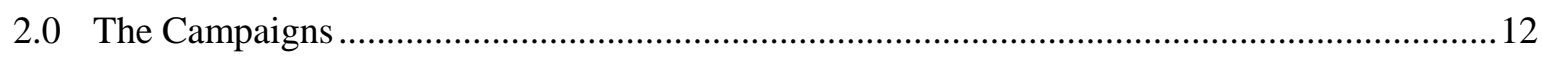

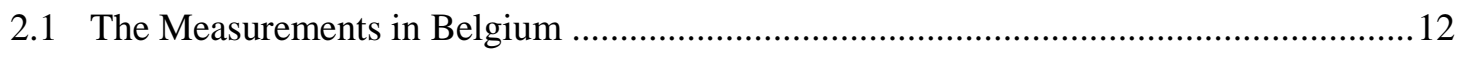

2.1.1 Site Survey in Belgium ......................................................................... 12

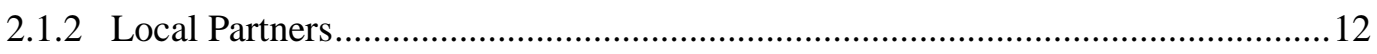

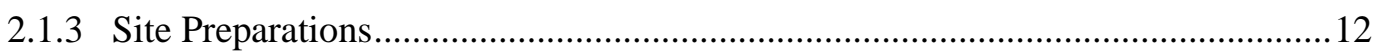

2.1.4 Deployment and Operation of the Mobile Noble Gas System .............................13

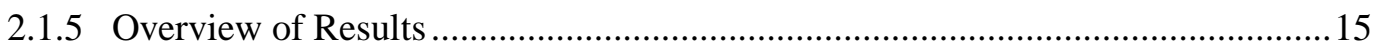

2.1.6 Conclusion Belgian campaign ........................................................................ 19

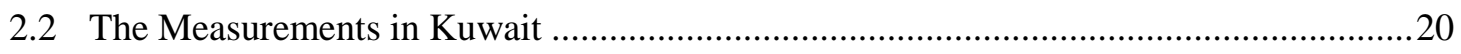

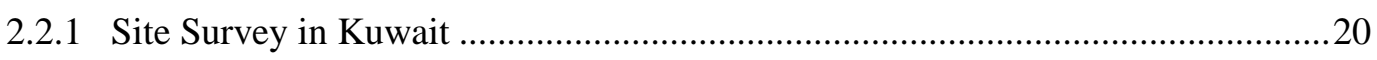

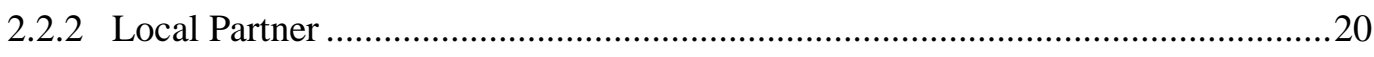

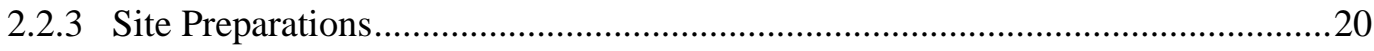

2.2.4 Deployment and Operation of the Noble Gas System.......................................21

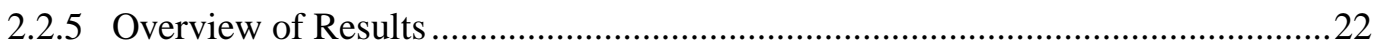

2.2.6 Conclusions for the Kuwait Campaign ……...................................................2 26

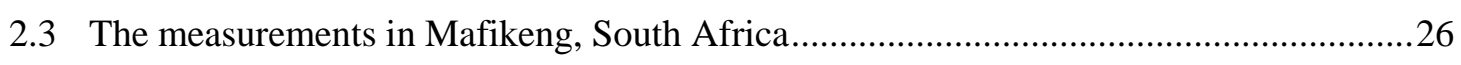

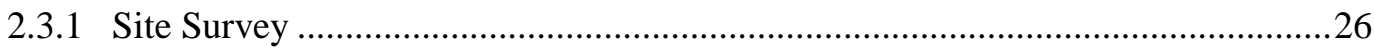

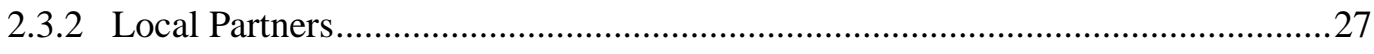

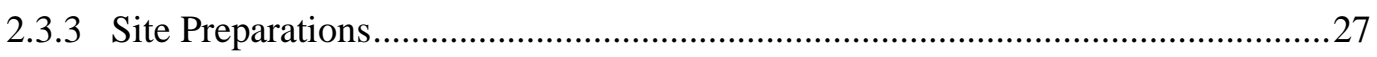

2.3.4 Deployment and Operation of the Noble Gas System........................................2 27

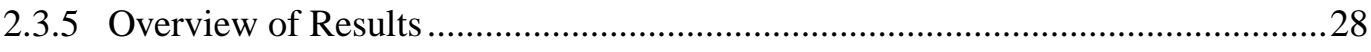

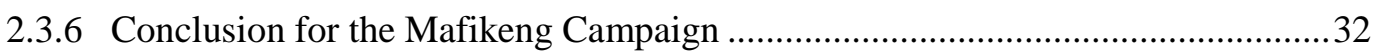

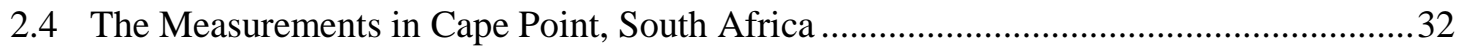

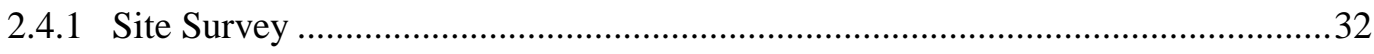

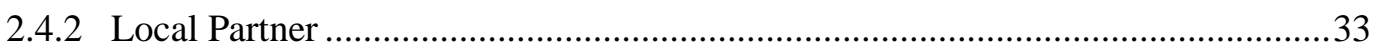

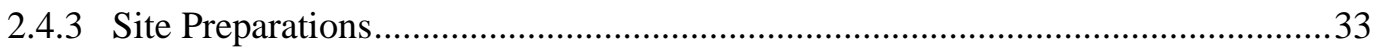

2.4.4 Deployment and Operation of the Noble Gas System..........................................33

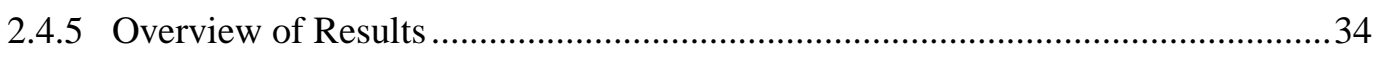

2.4.6 Conclusion from the Cape Point Campaign ......................................................... 35 


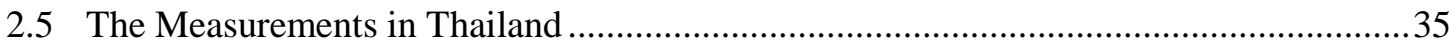

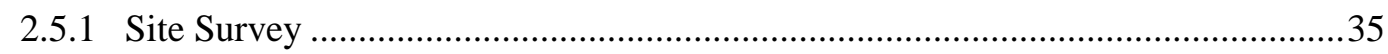

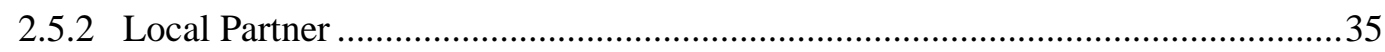

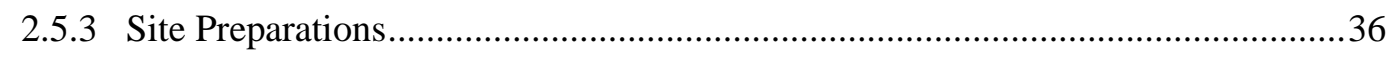

2.5.4 Deployment and Operation of the Noble Gas System...........................................36

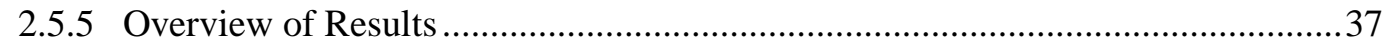

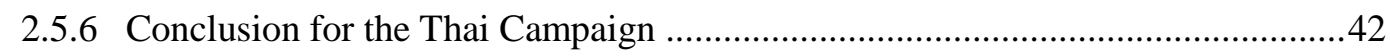

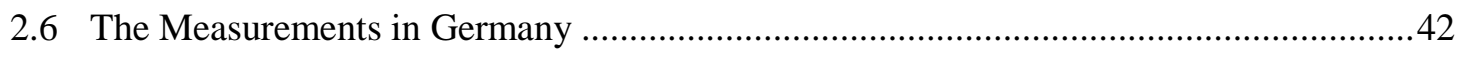

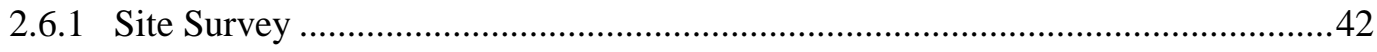

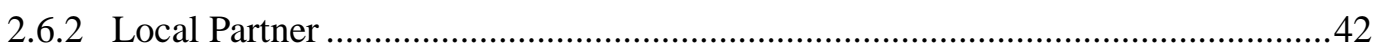

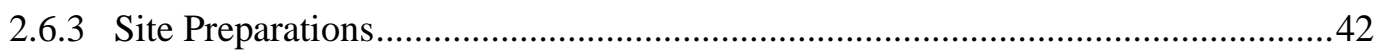

2.6.4 Deployment and Operation of the Mobile Noble Gas System .............................42

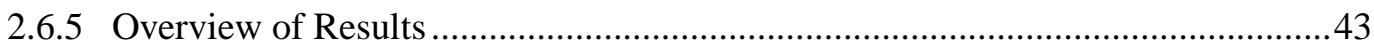

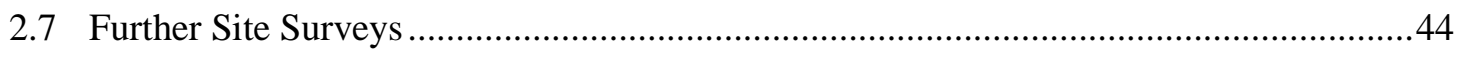

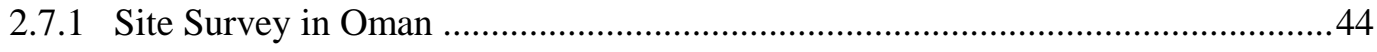

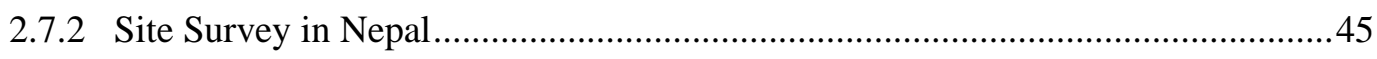

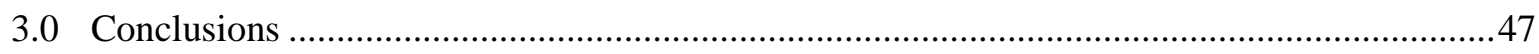

4.0 Overview of Papers, Presentations, and Posters ..................................................................49

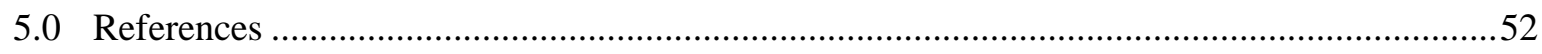

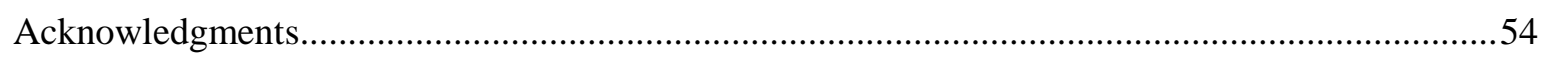




\section{Figures}

2.1 The Stack of the Fleurus Facility, Which is Used by Both IRE and MDS Nordion and the Hot Cells at IRE, Where ${ }^{99}$ Mo is Produced

2.2 The Sites Close to IRE in South Belgium and All the Sites ................................................

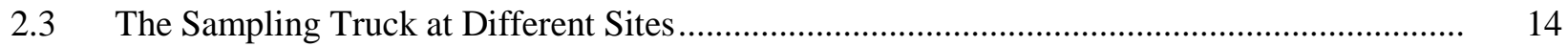

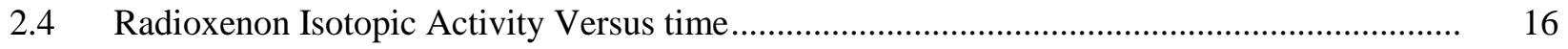

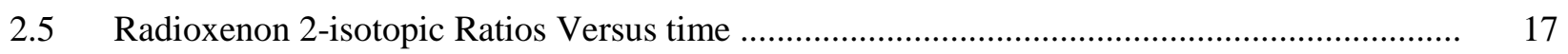

2.6 Belgian Field Measurements Compared to Simulations in the 3-Isotope Ratio Graph............ 18

2.7 Belgian Field Measurements Compared to Simulations in the 4-Isotope Graph ................... 19

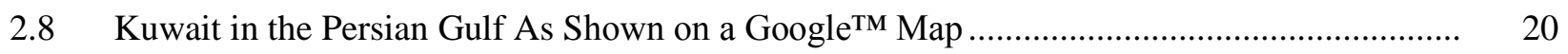

2.9 A Ground Drawing of the Station Indicating the Position of the SAUNA and the RASA Particulate System

2.10 From Left to Right: Packing of the SAUNA in Stockholm, Delivery at the Station the Boxes in Front of the Station, Filling of the Lead Shields, and Making Electrical Connections.

2.11 The Stable Xenon Versus time During the Kuwait Campaign.

2.12 From Left to Right: FOI Staff Operating the SAUNA, Local Staff Operating the SAUNA, Lectures at the KISR, and Preparing the SAUNA for Return

2.13 Time Series of the Radioxenon Isotopes 131m, 133 and 135 .............................................. 23

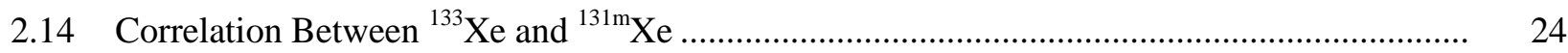

2.15 Projected Network Coverage for the Kuwait Station With 2006 SRS Fields ......................... 25

2.16 Actually Encountered Network Coverage for Kuwait with SRS Data Pertaining to

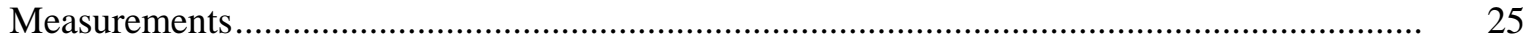

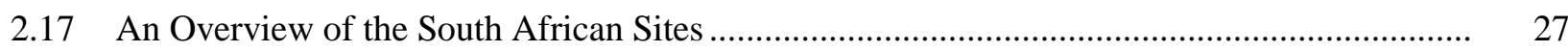

2.18 The Mafikeng Site Showing the Building Where the Equipment was Deployed, the Inlet of the SAUNA, and the SAUNA System Inside the Building, Framed by Local Wildlife ........... 28

2.19 From Left to Right: the Pelindaba Facility, the Stack from NTP, Calibrating the HP Ge Detector and the Aluminium Bottle with the Stack Sample in Front of the Detector. ............. 28

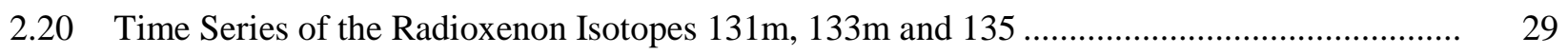

2.21 The WEB-GRAPE Result for the Three Measurements from December 2-3 ......................... 29

2.22 Projected Network Coverage for the Mafikeng Station with 2007 SRS Fields....................... 30

2.23 Actually Encountered Network Coverage for Mafikeng with SRS Data Pertaining to

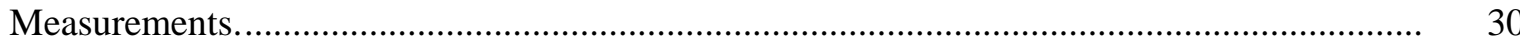

2.24 The Three-isotopic Graph of the Simulation of Radioxenon Isotopes in a HEU Target Irradiated with the Parameters Common for the NTP Facility .............................................. 31

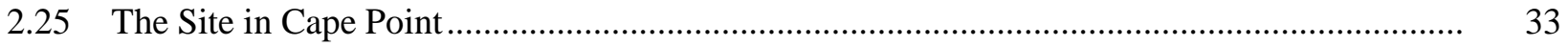

2.26 Beta-gamma and Gamma Spectra for the Summed Sample Spectra Measured by Detector 1 and Detector 2 .

2.27 Projected Network Coverage for the Cape Point Station with 2007 SRS Fields ..................... 35 
2.28 Actually Encountered Network Coverage for Cape Point with SRS Data Pertaining to Measurements.

2.29 From Left to Right: a Local Buddhist Temple, the Installation of the Air-Conditioning, the Setup of the SAUNA, Operating the SAUNA. .................................................................. 36

2.30 The Stable Xenon Versus time During the Thai Campaign. ................................................. 37

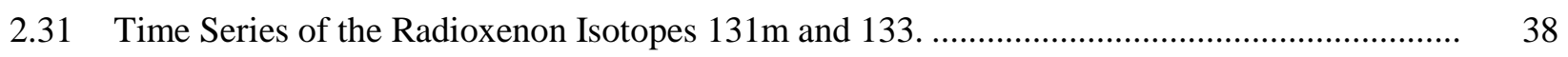

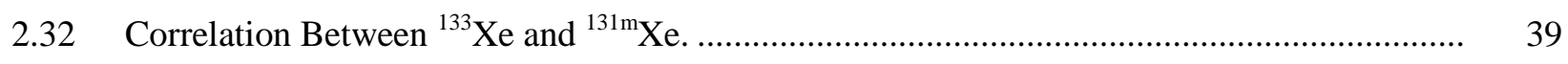

2.33 Projected Network Coverage for the Chiang Mai Station with March, April, and May 2007 SRS fields ...................................................................................................................... 40

2.34 Actually Encountered Network Coverage for Chiang Mai with SRS Data Pertaining to Measurements ...................................................................................................... 41

2.35 Backtracking Example for the Chiang Mai Measurement of April 23 at 03:00 UTC............. 41

2.36 Activity Concentration of the Relevant Radioxenon Isotopes............................................... 43

2.37 Four-Isotopic Graph Indicating the Measurements, a Reactor Cycle, the Discrimination Line, and Two Types of Nuclear Explosions ................................................................... 44

\section{Tables}

1.1 Overview of the Field Locations of This Project................................................................... 11

2.1 Different Areas Around the IRE Facility Where Air was Sampled.......................................... 13

2.2 Parameters Used for the Calculations of the Radioxenon Inventory at the IRE Facility for a

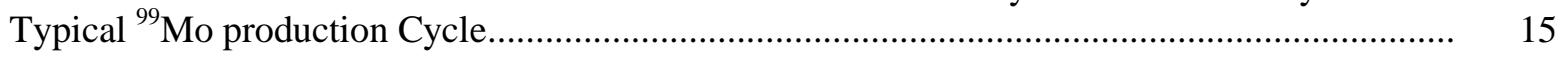

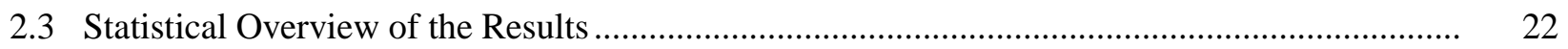

2.4 Parameters Used for the Calculations of the Radioxenon Inventory of the NTP Facility ........... 31

2.5 Statistical Overview of the Results ..................................................................................... 38

4.1 EU/JA-II project Presentations and Publications............................................................... 49 


\subsection{Introduction}

\subsection{Comprehensive Nuclear-Test Ban-Treaty}

The worldwide monitoring for nuclear explosions has direct application to the Comprehensive Nuclear-Test-Ban Treaty (CTBT), which was opened for signature in 1996 but has yet to be ratified by all of the key countries necessary for its entry into force (EIF). As part of the CTBT, an international monitoring system (IMS) consisting of seismic, hydroacoustic, and infrasound technologies as well as radionuclide detection was developed on paper, and efforts have been underway for more than 15 years to finally establish the system. The radionuclide measurement component of the IMS can be further subdivided into radioactive particulates and radioactive xenon gas to identify possible radionuclide source regions (UNGA 1996; Dahlman et al. 2009). When the IMS network is complete, there will be 321 monitoring stations worldwide including 80 radionuclide particles, of which at least 40 will also be equipped with radioxenon measurement systems at CTBT EIF. After CTBT EIF, possibly an additional 40 stations could officially be part of the IMS.

\subsection{Xenon Measurements in the International Monitoring System}

Radioactive xenon gas monitoring is a fundamental and highly sensitive technique for the detection of underground or underwater nuclear explosions. Of all the verification technologies, it is, together with radionuclide particulate monitoring, the only technique that has the potential to provide unmistakable proof of a nuclear explosion (De Geer, 1996; Bowyer et al., 2002). This was recognized when the CTBT was negotiated, yet little information was known about global radioactive xenon backgrounds at the time, and since then, the backgrounds have changed.

In 1999, the first phase of an international collaborative project was initiated to develop radioactive xenon (radioxenon) measurement technology, demonstrate and test equipment and software algorithms, and attempt to understand backgrounds. This International Noble Gas Experiment (INGE) is still an ongoing project as of 2009. The initial site for the INGE project was Freiburg, Germany, where information already existed about radioxenon backgrounds. However, the technology being used at that location was only very sensitive to one xenon isotope (Xe-133), and the measurements were an average over several days to a week. Since the equipment fielded in Freiburg was much more sensitive than the older design and included a capability to measure four xenon isotopes (Xe-131m, Xe-133, Xe-133m, and Xe-135), a high time resolution (from two to three samples per day), and a lower detection threshold $\left(0.1 \mathrm{mBq} / \mathrm{m}^{3}\right.$ vs. $\left.>1 \mathrm{mBq} / \mathrm{m}^{3}\right)$, in the first phase of these INGE experiments much was learned about backgrounds in Frieburg, even at this well-characterized site.

After the first phase of the INGE experiment was completed, equipment was deployed at several other locations including Guangzhou, China, Spitzbergen, Norway, Dubna, Russia, and Tahiti, French Polynesia. With the exception of French Polynesia where a zero background of radioxenons was expected and has been observed for several years, all of these locations yielded somehow unexpected results. In general, the sites had higher than expected isotope concentrations, more frequently, and with more variety of xenon isotopes measured than expected. 
Later in the INGE experiment, other sites locations came online including Ottawa Canada, Stockholm, Sweden, Paris France, Melbourne, Australia and several other locations. At these locations, it was discovered that the backgrounds were still unpredicted and surprising. It was suggested, using the data from Canada, that medical isotope production may have been contributing to radioxenon backgrounds with a much stronger influence than ever predicted. Today, many believe that xenon backgrounds are mainly caused by medical isotope production, but it is still fair to say that global radioxenon backgrounds still have not been adequately characterized.

\subsection{Worldwide Radioxenon Background Concentrations}

To ensure the quality and accuracy of the current and future CTBT radioxenon gas measurement capabilities, it is important to know the radioxenon gas background that can be expected in other regions of the world, where currently no IMS stations exist. In addition, a methodology for the categorization of radioxenon measurements to determine whether the event was a nuclear explosion versus medical isotope or reactor release detected by the IMS needs to be developed. Radioxenon gas field measurements are the best way to achieve this and to provide answers to such unknowns.

Southern Africa, South Asia, and the Persian Gulf are areas that could see air that originates from known regions with nuclear facilities but no radioxenon background data are currently available because no IMS stations exist in these regions. These locations became the basis for a series of measurements designed to measure global radioxenon backgrounds as the first phase of a pilot project called the European Union (EU) project.

\subsection{Sponsoring of the Campaigns}

The U.S. Army Space \& Missile Defense Command sponsored PNNL's work on this project, as well as the work to compile this report.

In the aftermath of the first North Korean nuclear test in 2006, the Council of the EU adopted, under Title V of the European Union Treaty on June 28 2007, a Council Joint Action (2007/468/CFSP) to support activities of the Comprehensive Nuclear-Test-Ban Treaty Organization (CTBTO) to strengthen its monitoring and verification capabilities within the framework of implementing the EU strategy against the proliferation of weapons of mass destruction.

During preliminary discussions, the Swedish Defense Research Institute (FOI) proposed to support this action and offered to participate with its mobile Swedish Automatic, Unattended Noble gas Analyzer (SAUNA) radioxenon system for use in making measurements. In addition, the French Atomic Agency (CEA) initially offered to participate with its xenon measurement system (SPALAX), though during subsequent discussions, it was determined that the SPALAX was not available. Lastly, the German Radiation Protection Agency (BfS) offered to measure samples when necessary. The Swedish SAUNA system had already been used in several field campaigns and was thus well evaluated (Ringbom et al., 2003). The system delivers data with detection limits similar to the IMS version (SAUNA-II) for the four relevant xenon isotopes $\left({ }^{131 \mathrm{~m}} \mathrm{Xe},{ }^{133 \mathrm{~m}} \mathrm{Xe},{ }^{133} \mathrm{Xe}\right.$ and $\left.{ }^{135} \mathrm{Xe}\right)$, and the data are therefore directly applicable to the IMS measurement scenario. The SAUNA equipment requires a covered and air-conditioned area of around $6 \times 3 \mathrm{~m}$ and a floor that can take a load of $700 \mathrm{~kg} / \mathrm{m}^{2}$. The required power is a maximum $8 \mathrm{~kW}$ (50 Hz, $380 \mathrm{~V}$ three phases). 
Because of the historical United States role in radioxenon measurements, the U.S. Army Space \& Missile Defense Command (SMDC) / Department of Defense (DoD) also offered to assist in obtaining these measurements through the Pacific Northwest National Laboratory (PNNL), where the first automatic radioxenon measurement system (the ARSA) was created. The EU project was hence a collaboration between the EU and the United States to obtain global radioxenon measurements at several locations around the world. The SMDC, through PNNL, made equipment (a SAUNA-II system) and personnel available for these measurements.

It was critical to make measurements of the radioxenon concentration levels with equipment especially designed for the task. The SAUNA system, which is employed by the United States in its IMS stations as well as many other non-U.S. IMS locations provides very reliable radioxenon measurements and can measure all of the CTBT-relevant radioxenon isotopes $\left({ }^{131 \mathrm{~m}} \mathrm{Xe},{ }^{133 \mathrm{~m}} \mathrm{Xe},{ }^{133} \mathrm{Xe}\right.$ and $\left.{ }^{135} \mathrm{Xe}\right)$ to very low concentrations compared to other xenon measurement systems employed in the IMS because it uses beta-gamma coincidence spectrometry, instead of high-purity gamma spectrometry. In addition, the SAUNA system has been proven to be much more reliable than other systems in the IMS.

All of the data collected, as well as the interpretation of these data, were made available to the sponsors and to the host institutes. This report gives an overview of all campaigns performed in the framework of this project, its results, and an interpretation of the data.

\subsection{Field Measurement Campaigns}

Table 1.1 shows the locations were the radioxenon measurement campaign was performed. The choice of locations was based on areas where no IMS radioxenon stations were installed and where, in a wider area, nuclear facilities were present: Southern Africa, South Asia, Europe and the Persian Gulf. Error! Reference source not found. Table 1.1 also presents the time period, which equipment was used, and the sponsor of the equipment.

Table 1.1. Overview of the Field Locations of This Project

\begin{tabular}{cccc}
\hline Location & Time period & Equipment & $\begin{array}{c}\text { Equipment } \\
\text { Sponsor }\end{array}$ \\
\hline $\begin{array}{c}\text { Belgium (region around the } \\
\text { RPF of Fleurus) }\end{array}$ & June 25 June to July 17, 2008 & $\begin{array}{c}\text { Mobile SAUNA / } \\
\text { SAUNA Lab }\end{array}$ & FOI \\
Safat, Kuwait & September 5 - December 1, 2008 & SAUNA-II & FOI \\
Mafikeng, South Africa & November 10 - December 19, 2008 & SAUNA-II & PNNL \\
Cape Point, South Africa & January 5 - February 4, 2009 & SAUNA-II & PNNL \\
Chiang Mai, Thailand & February 22 - April 29, 2009 & SAUNA-II & FOI \\
Germany (near Isar-I NPP) & March 12-15, 2008 & Mobile SAUNA / & FOI/BfS \\
\hline
\end{tabular}

The originally planned campaigns in Kathmandu, Nepal and Muscat, Oman had to be cancelled due to logistical and other reasons. However, these locations were still visited, and local contacts were made so that future measurements could, in principle, be made there. 


\subsection{The Campaigns}

This section of the report gives an overview of all sites that are part of this project. Each subsection below provides a description of the site survey performed, an overview of the local scientific partners with whom the project cooperated, the site preparations, the deployment and operation of the radioxenon system, and an overview of results and some conclusions.

\subsection{The Measurements in Belgium}

\subsubsection{Site Survey in Belgium}

The Belgian Nuclear Research Centre (SCK-CEN) in Mol and the National Institute for Radioelements (IRE) in Fleurus, Belgium were visited on April 22 - 24, 2008 as possible sites for performing measurements. After long negotiations, IRE decided to join the campaign and cooperate. Measurements were planned to be taken in June and July 2008.
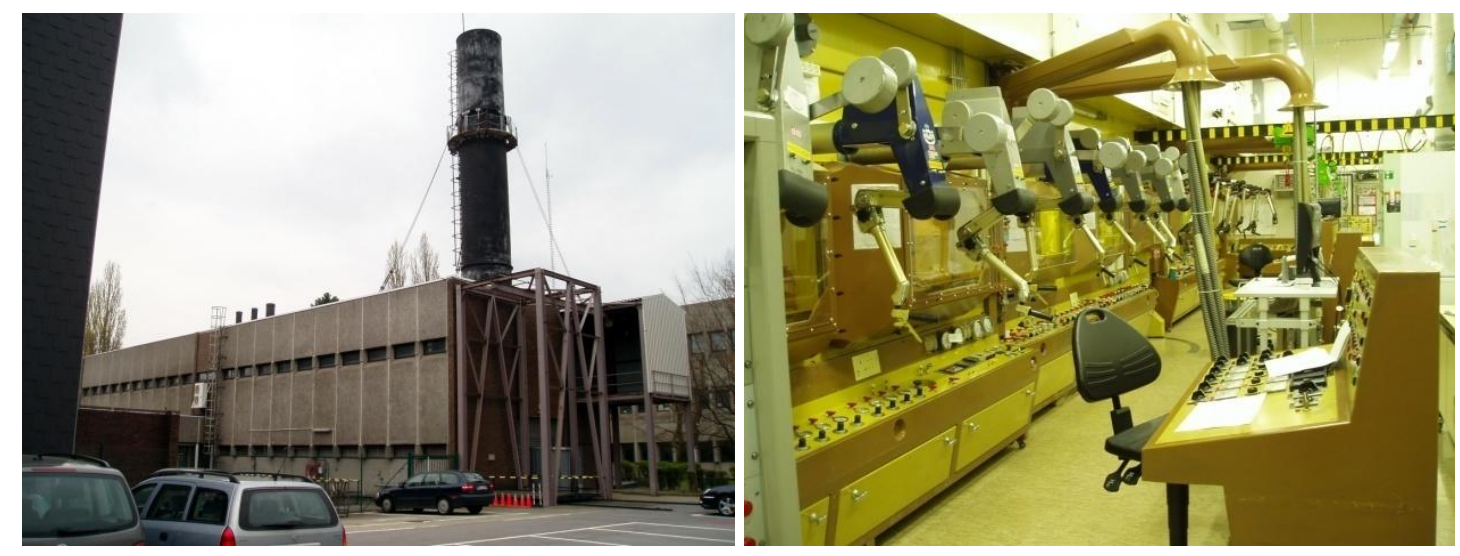

Figure 2.1. The Stack of the Fleurus Facility (Left), Which is Used by Both IRE and MDS Nordion and the Hot Cells at IRE, Where ${ }^{99}$ Mo is Produced (Right)

\subsubsection{Local Partners}

- Belgian Federal Agency on Nuclear Control (FANC), Brussels, Belgium

- IRE, Fleurus, Belgium

- Studiecentrum voor Kernenergie - Centre d'Etude de l'Energie Nucléaire (SCK-CEN), Mol, Belgium

\subsubsection{Site Preparations}

No technical preparations had to be made in Belgium because the FOI team brought and used their mobile sampling equipment, which was mounted in a truck for the collections for this part of the campaign. Due to availability of equipment and other issues, it was determined that it was acceptable to collect samples at this site and have the measurements of the radioxenon concentrations take place offsite. It was thought that this would likely be a reasonable solution, since it was expected that the radioxenon 
concentrations would be high in this vicinity, close to a radiopharmaceutical facility (RPF). FOI upgraded and calibrated their equipment (SAUNA II system and mobile system) at their laboratory in Stockholm.

\subsubsection{Deployment and Operation of the Mobile Radioxenon System}

The first measurement campaign in and around the RPF in Fleurus, Belgium with the mobile SAUNA-II sampler started June 25 and was completed on July 17, 2008. The samples taken with a mobile sampling unit in Belgium were sent daily to the FOI laboratory for analysis through DHL. An overview of the sites is listed in Table 1.1 and shown in Figure 2.1.

The daily sampling routine that was performed was as follows:

- Transport from hotel to site

$0.5-2.5 \mathrm{~h}$

- Assembling and start

$0.5 \mathrm{~h}$

- Sampling (2 samples/day)

$12 \mathrm{~h}$

- Transfer to the transport column $3 \mathrm{~h}$

- Disassembling and loading

$1 \mathrm{~h}$

- Driving back

$0.5-2 \mathrm{~h}$

- Preparing for next day

$0.5-1 \mathrm{~h}$

Total daily occupation was $18-22 \mathrm{~h}$, which is very demanding for a team of two people.

Table 2.1. Locations Around the IRE Facility Where Air was Sampled

\begin{tabular}{|c|c|c|c|c|}
\hline No. & Name & Lat & Long & Distance from IRE $(\mathrm{km})$ \\
\hline 0 & IRE stack & $50^{\circ} 27^{\prime} 03^{\prime \prime} \mathrm{N}$ & $4^{\circ} 32^{\prime} 07^{\prime \prime} \mathrm{E}$ & 0 \\
\hline 1 & SCK-CEN, Mol & $51^{\circ} 13^{\prime} 09^{\prime \prime} \mathrm{N}$ & $5^{\circ} 05^{\prime} 36 " \mathrm{E}$ & 94 \\
\hline 2 & Chausée Romaine,Gembloux & $50^{\circ} 34^{\prime} 56^{\prime \prime} \mathrm{N}$ & $4^{\circ} 41^{\prime} 25 " \mathrm{E}$ & 18.3 \\
\hline 3 & Villers-la-Ville & $50^{\circ} 35^{\prime} 26^{\prime \prime} \mathrm{N}$ & $4^{\circ} 31^{\prime} 36 " \mathrm{E}$ & 15.5 \\
\hline 4 & Villers-la-Ville 2 & $50^{\circ} 35^{\prime} 17^{\prime \prime} \mathrm{N}$ & $4^{\circ} 31^{\prime} 48^{\prime \prime} \mathrm{E}$ & 15.3 \\
\hline 5 & Lambusart & $50^{\circ} 27^{\prime} 15^{\prime \prime} \mathrm{N}$ & $4^{\circ} 33^{\prime} 24 " \mathrm{E}$ & 1.6 \\
\hline 6 & Chausée de Charleroi 1, Fleurus & $50^{\circ} 27^{\prime} 30^{\prime \prime} \mathrm{N}$ & $4^{\circ} 31^{\prime} 44 " \mathrm{E}$ & 0.9 \\
\hline 7 & Avenue de Spirou, Fleurus & $50^{\circ} 27^{\prime} 34^{\prime \prime} \mathrm{N}$ & $4^{\circ} 32^{\prime} 34^{\prime \prime} \mathrm{E}$ & 1.1 \\
\hline 8 & Zwartberg & $51^{\circ} 00^{\prime} 40^{\prime \prime} \mathrm{N}$ & $5^{\circ} 31^{\prime} 14^{\prime \prime} \mathrm{E}$ & 93.2 \\
\hline
\end{tabular}




\begin{tabular}{|c|c|c|c|c|}
\hline 9 & Bassenge & $50^{\circ} 45^{\prime} 57^{\prime \prime N}$ & $5^{\circ} 34^{\prime} 08^{\prime \prime} \mathrm{E}$ & 80.9 \\
\hline
\end{tabular}

Table 2.1. (continued)

\begin{tabular}{|c|c|c|c|c|}
\hline No. & Name & Lat & Long & Distance from IRE $(\mathrm{km})$ \\
\hline 10 & Floriffoux & $50^{\circ} 26^{\prime} 47^{\prime \prime} \mathrm{N}$ & $4^{\circ} 46^{\prime} 32^{\prime \prime} \mathrm{E}$ & 17 \\
\hline 11 & Chausée de Charleroi 2, Fleurus & $50^{\circ} 27^{\prime} 56^{\prime \prime} \mathrm{N}$ & $4^{\circ} 32^{\prime} 10^{\prime \prime} \mathrm{E}$ & 1.6 \\
\hline 12 & Bâlatre & $50^{\circ} 29^{\prime} 10^{\prime \prime} \mathrm{N}$ & $4^{\circ} 38^{\prime} 03^{\prime \prime E}$ & 8 \\
\hline 13 & Huy & $50^{\circ} 32^{\prime} 31^{\prime \prime} \mathrm{N}$ & $5^{\circ} 15^{\prime} 24^{\prime \prime} \mathrm{E}$ & 52 \\
\hline
\end{tabular}
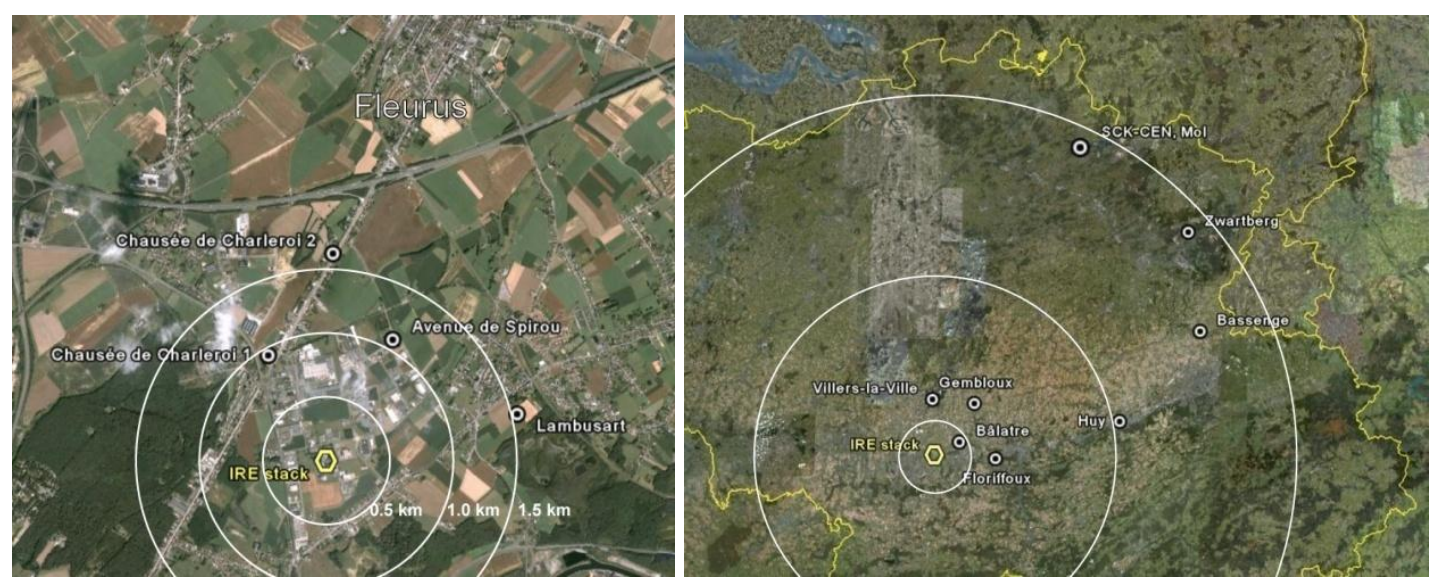

Figure 2.2. The Sites Close to IRE in South Belgium (top) and All the Sites (lower)
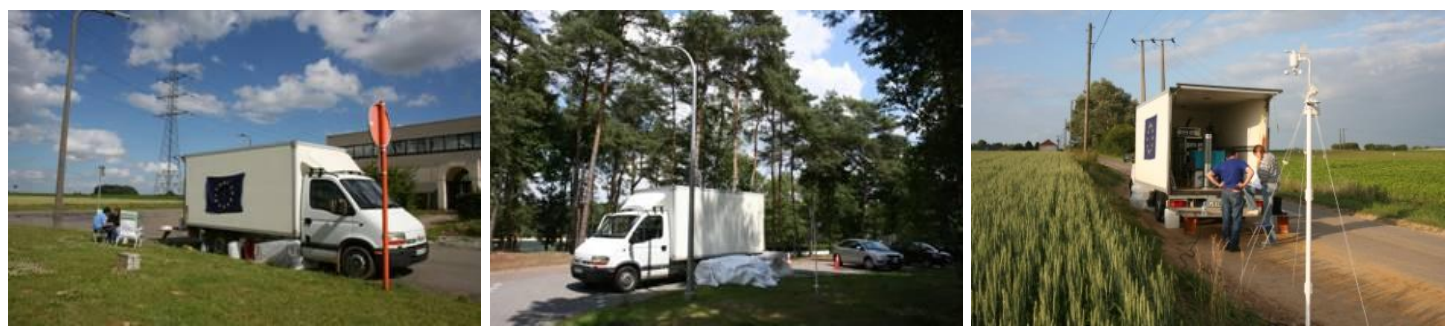

Figure 2.3. The Sampling Truck at Different Sites

The two samples that were collect each day were transported daily via courier to Stockholm, Sweden, where low-level radioactive measurements were performed. The cooperating local partners in Belgium (IRE in Fleurus, the FANC in Brussels, and SCK-CEN in Mol) were very supportive in this measurement campaign: 
- The IRE gave permission to take four samples during ${ }^{99}$ Mo production directly from their stack in a vacuum-pumped archive bottle. They further provided information on the daily operations plan during the campaign.

- The SCK-CEN provided daily high resolution wind field forecasts, which were used to plan the setup of the truck with the sampler the following day.

- The CTBTO provided four daily predictions of plume locations emanating from the IRE stack assuming release times between 7-10 UTC and 12-15 UTC. Further, one forecast and one analysis run (to confirm the prediction) per day was provided.

- The FANC provided a laptop with VPN access to their radiological monitoring network, Telerad, which included stack measurements from the Fleurus facility in 10 minutes resolution. This last set of data remained confidential, but was available to the CTBTO during the measurements.

At the FOI laboratory in Stockholm, the following was performed:

- Two columns loaded with a radioxenon sample arrived at approximately 9 a.m.

- A pre-measurement on $\mathrm{NaI}(\mathrm{Tl})$ detector was performed to check for high activity

- Processing of the first column started at 10 a.m.

- The second column was loaded at around 10 p.m.

\subsubsection{Overview of Results}

Successful radioxenon measurements were taken in Belgium in and around the RPF of Fleurus. This was the first time such measurements were performed, and the results greatly assist with interpreting and understanding data from the IMS network. Measurement of 31 samples around the IRE and three inside the stack were sampled (a sample had a leak and hence was lost). All field samples were collected on charcoal columns and transported via an express parcel service to the laboratory in Stockholm, Sweden. They were received the next morning and analyzed immediately so no important information would be lost because some of the radionuclides have short half lives (Xe-135 half life $=9.1$ hours).

To determine the concentration of radioxenon that might be expected and predict the theoretical isotopic ratios, irradiation computations were performed with Scale 5.1/Origen-ARP (ORNL, 2006) and Nuclear Analysis 2.0 - Decay and Irradiation Software (Vilece, 1996) with nuclear data from ENDF/BVII.0 (2009). The parameters shown in Table 2.2 were used - they are typical for the IRE facility. The calculations don't take any isotopic mixtures that might happen during different (other) processes at the facility into account such as contributions from Iodine decay from past samples.

Table 2.2. Parameters Used for the Calculations of the Radioxenon Inventory at the IRE Facility for a Typical ${ }^{99}$ Mo production Cycle (Salacz, 1985; Bonet et al., 2005)

$\begin{array}{lc}\left.\text { Neutron Flux (n/cm }{ }^{2} \mathrm{~s}\right) & 1.5 \times 10^{14} \\ \text { Irradiation time (hours) } & 220\end{array}$

Initial Isotope Inventory per target (grams) 


\begin{tabular}{cc}
\hline${ }^{235} \mathrm{U}$ & 29.4 \\
${ }^{238} \mathrm{U}$ & 2.2 \\
${ }^{27} \mathrm{Al}$ & 210 \\
Number of targets irradiated & 7 \\
Cooling time after irradiation (hours) & 36 \\
Dissolution time (hours) & 1 \\
\hline
\end{tabular}

Figure 2.4 shows the radioxenon activity versus time. The dashed lines indicate the decoupling of the radioxenon isotopes from their parent nuclides due to the dissolution. Around $2.6 \times 10^{14} \mathrm{~Bq}^{133} \mathrm{Xe}$ was created after the irradiation.

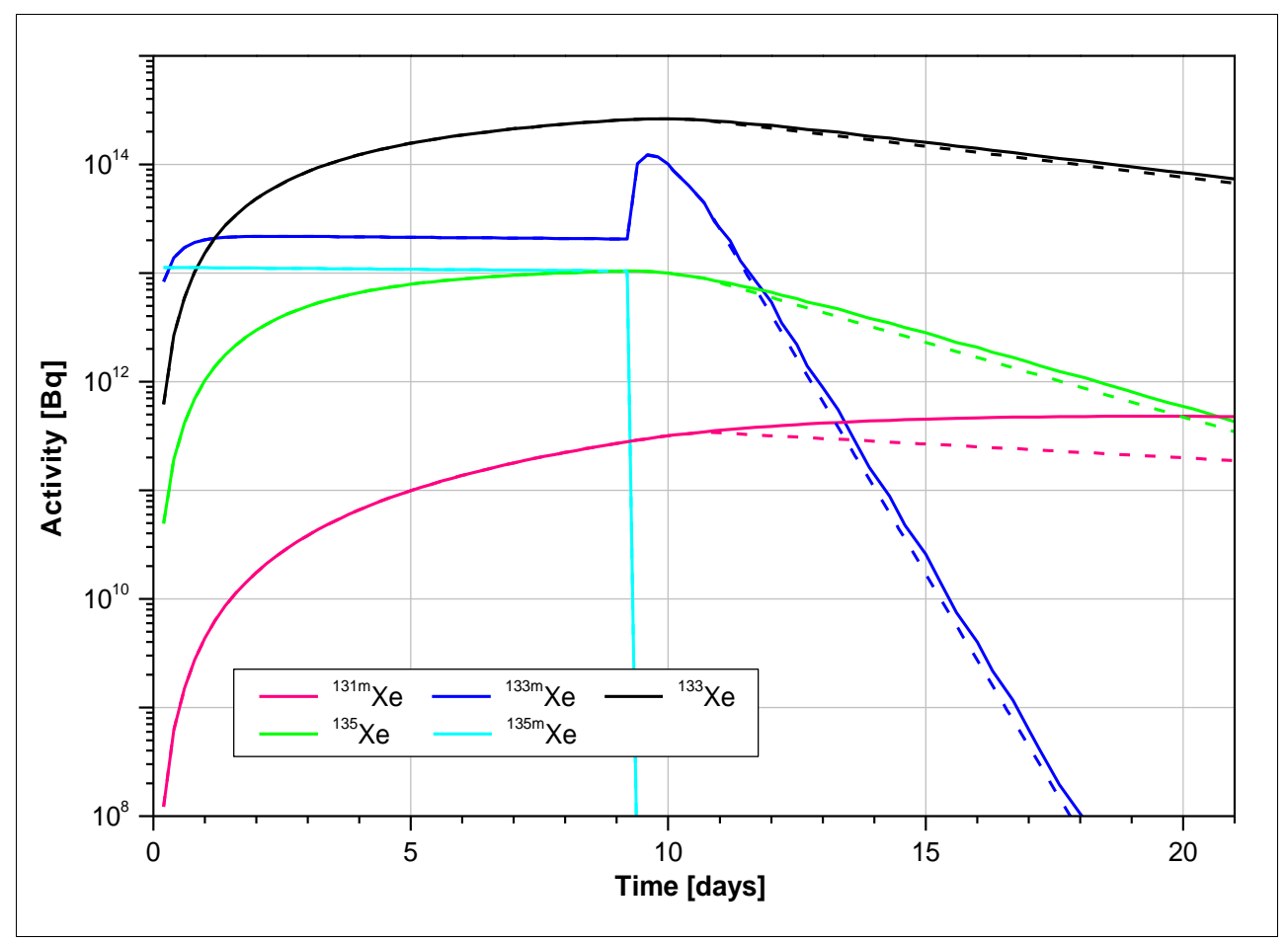

Figure 2.4. Predicted Radioxenon Isotopic Activity Versus Time from the IRE Process

Figure 2.5 shows the ratio of ${ }^{131 \mathrm{~m}} \mathrm{Xe},{ }^{133 \mathrm{~m}} \mathrm{Xe}$ and ${ }^{135} \mathrm{Xe}$ each to ${ }^{133} \mathrm{Xe}$ versus time. The dashed lines indicate the decoupling of the radioxenon isotopes from their parent nuclides expected during dissolution of fuel to collect the ${ }^{99} \mathrm{Mo}$. 


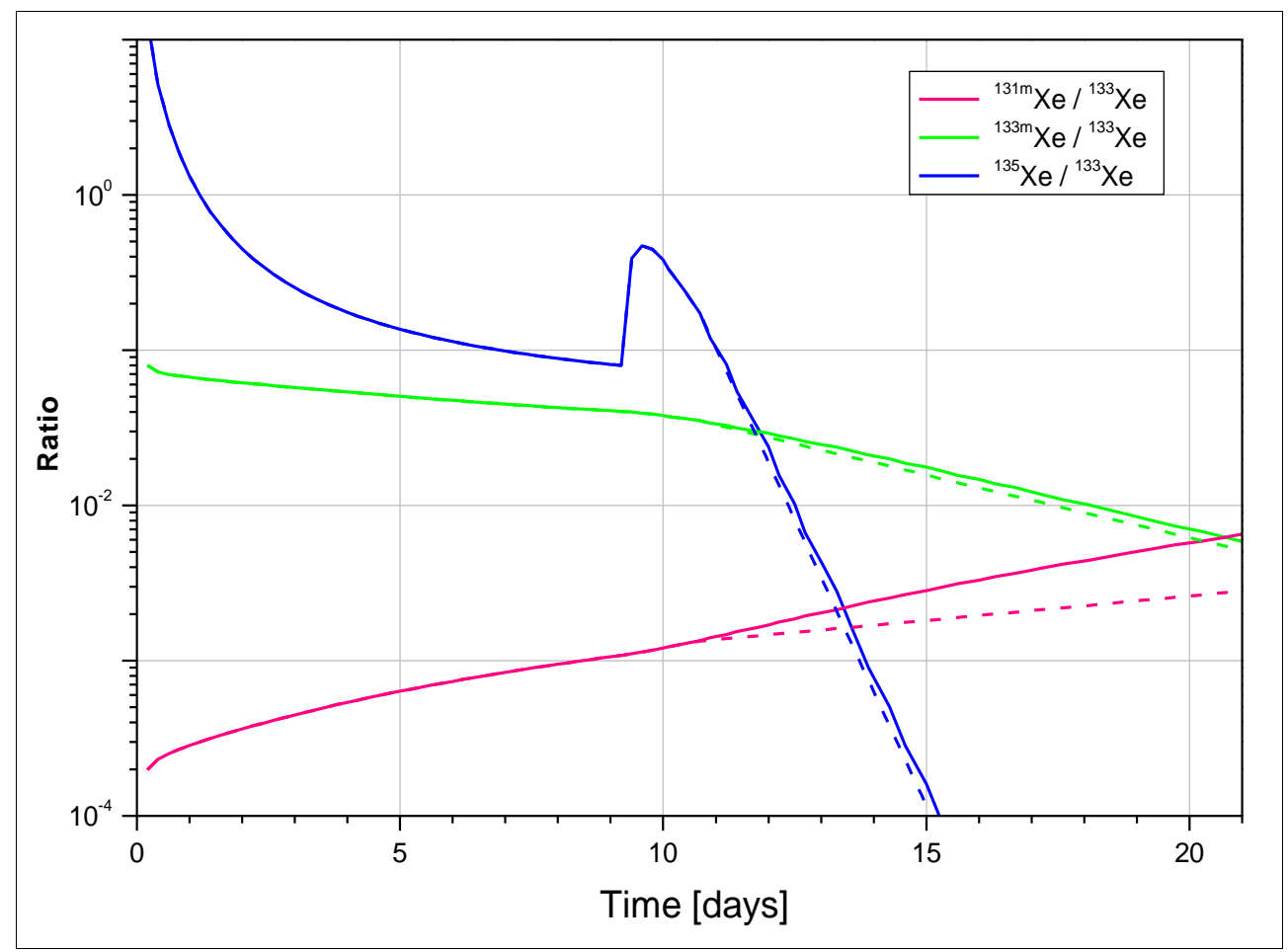

Figure 2.5. Radioxenon 2-isotopic Ratios Versus time

The ratio of ${ }^{133 \mathrm{~m}} \mathrm{Xe} /{ }^{133} \mathrm{Xe}$ and ${ }^{135} \mathrm{Xe} /{ }^{133} \mathrm{Xe}$ are presented in Figure 2.6. The black line shows the simulated ratios, the grey dashed line shows the decoupled ratios after dissolution, and the red dashed line shows the discrimination line (Multiple Isotope Ratio Correlation) proposed by (Kalinowski et al., 2009). All CTBT-relevant radioxenon isotopes were measured several times during the campaign. One cluster of these measurements fits well with the simulations but another does not. This may be explained with mixtures that happen during different processes inside the facility, which can be the dissolution of ${ }^{235} \mathrm{U}$ targets for ${ }^{99}$ Mo production, the cleaning of the hot cells before and after a production cycle, the I production that will add the decay radioxenon products, ${ }^{133} \mathrm{Xe}$ production, etc. More information from these different processes is needed to understand all measurements. 


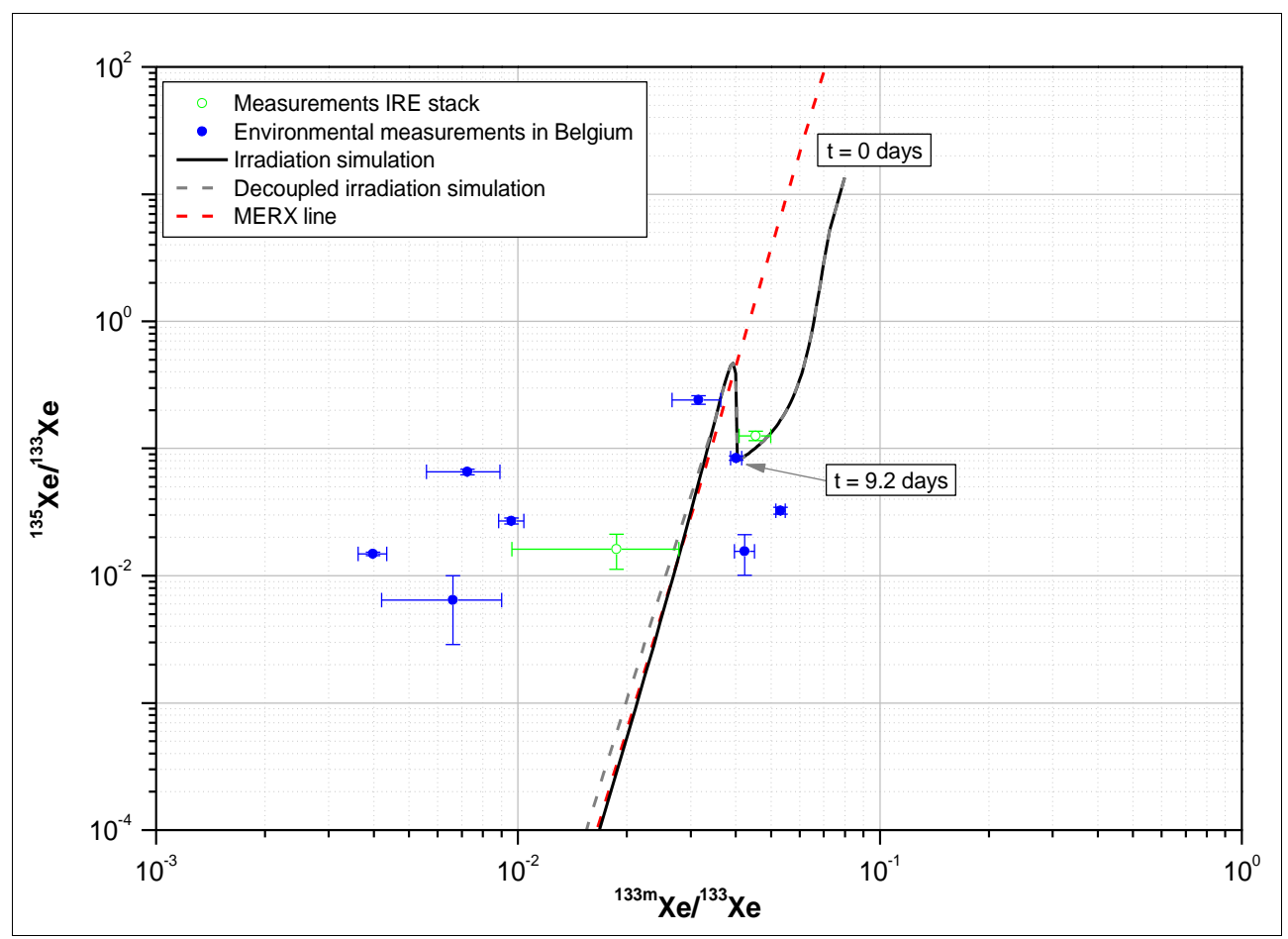

Figure 2.6. Belgian Field Measurements Compared to Simulations in the 3-Isotope Ratio Graph

The ratio of ${ }^{133 \mathrm{~m}} \mathrm{Xe} /{ }^{131 \mathrm{~m}} \mathrm{Xe}$ and ${ }^{135} \mathrm{Xe} /{ }^{133} \mathrm{Xe}$ are presented in Figure 2.7. The black line shows the simulated ratios, the grey dashed line shows the decoupled ratios, and the red dashed line shows the discrimination line. Most measurements in this graph are left of the simulations, i.e., more ${ }^{131 \mathrm{~m}} \mathrm{Xe}$ is present than expected. This can also be explained with mixtures during different processes inside the facility. Also, here more information is needed to understand and explain all measurements. 


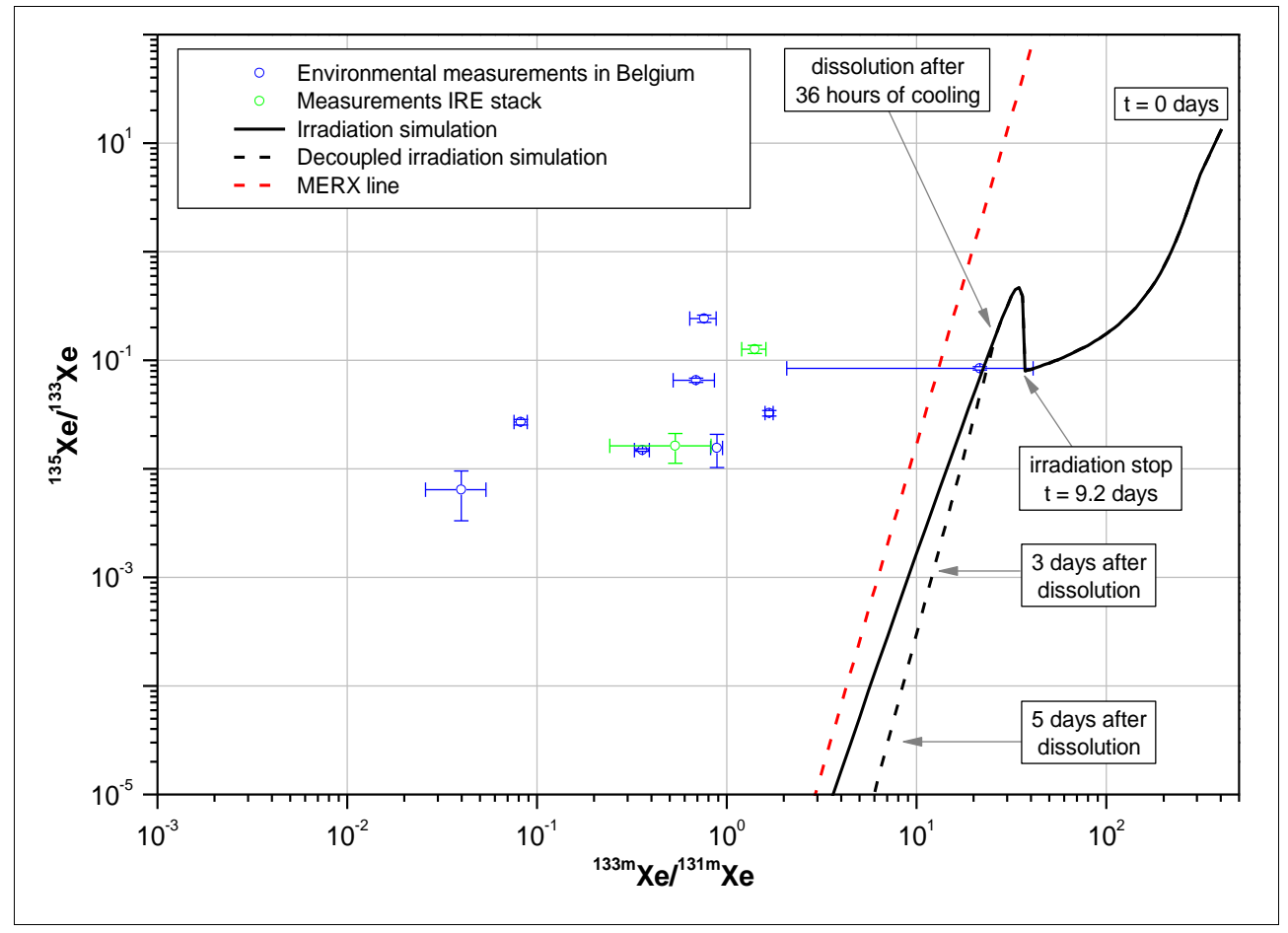

Figure 2.7. Belgian Field Measurements Compared to Simulations in the 4-Isotope Graph

\subsubsection{Conclusions From The Belgian Measurement Campaign}

The atmospheric concentrations of ${ }^{133} \mathrm{Xe}$ were in the range $0.7-4 \times 10^{5} \mathrm{mBq} / \mathrm{m}^{3}$. The majority of the samples contained radioxenon activities that were much stronger that normally measured in environmental atmospheric sampling. The highest concentration atmospheric samples contained 443,000 $\mathrm{mBq} / \mathrm{m}^{3}$, which is many orders of magnitude more than the highly sensitive SAUNA detector is designed to detect. This resulted in systematic effects not normally encountered. In particular, the strongest samples caused memory effects in the plastic cell of the detector that affected the samples that followed, as well as summation peaks in the spectra. However, the majority of the measurements produced reliable results. All samples contained ${ }^{133} \mathrm{Xe}$. The eighth atmospheric sample contained detectable amounts of all four isotopes (Figure 2.7). This was also the case for two of the stack samples.

The ${ }^{133} \mathrm{Xe}$ activity concentrations of the stack samples were in the range of $2 \times 10^{9}-4 \times 10^{10} \mathrm{mBq} / \mathrm{m}^{3}$. A simple estimate, taking the average stack airflow of $\sim 10^{5} \mathrm{~m}^{3} / \mathrm{h}$ and a 5-h release, indicates a total release of $\sim 10^{12} \mathrm{~Bq}$. The calculated maximum ${ }^{133} \mathrm{Xe}$ amount after a ${ }^{99}$ Mo production cycle was $2.6 \times 10^{14}$ Bq. This shows that around $2.6 \%$ of the produced ${ }^{133} \mathrm{Xe}$ enters the atmosphere. A nuclear power plant releases an average of $10^{9} \mathrm{~Bq} / \mathrm{day}$, according to reported releases. This release level of $2.6 \%$ is not unexpected, and in fact could be much worse depending on operational details of the plant, e.g., are the processes automated or manual, does the plant collect radioiodine, and the type of dissolution chemistry that is employed.

Initial assumptions were that concentrations measured from the RPF would be very high in the stack and outside of the facility, and these assumptions were confirmed. However, it was also hoped that the different processes inside the facility could be easily modeled and isotopic concentrations at distance predicted theoretically. This assumption did not hold true, so to reliably predict radioxenon 
concentrations at distance, actual stack measurements may be necessary. More information is needed here to understand all these measurements.

\subsection{The Measurements in Kuwait}

\subsubsection{Site Survey in Kuwait}

The first site survey took place in Kuwait January 6 - 10, 2008 (Figure 8). The Environment and Urban Development Division of the Kuwait Institute for Scientific Research (KISR) was designated as the scientific partner. During the site visit, it was agreed that measurements would be undertaken in September 2008 for 4-6 weeks. The building hosting the existing IMS particulate monitoring station (KWP40) was selected to host the equipment because it provided enough space for the SAUNA system and a climate-controlled environment.

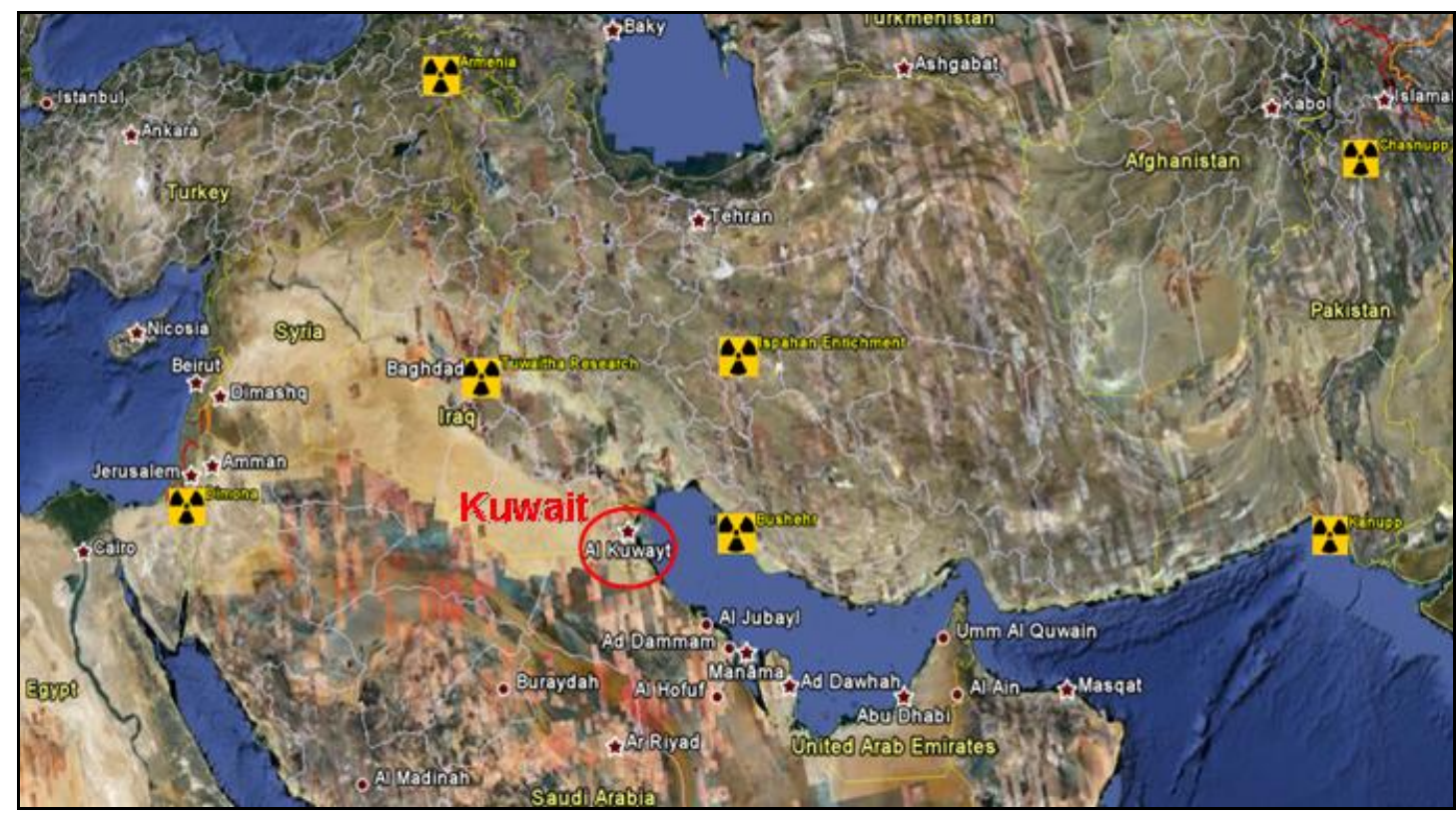

Figure 2.8 Kuwait in the Persian gulf As Shown on a Google ${ }^{\mathrm{TM}}$ Map. Nuclear facilities are indicated with the nuclear symbol.

\subsubsection{Local Partner}

The local partner in Kuwait was the Kuwait Institute for Scientific Research (KISR).

\subsubsection{Site Preparations}

The CTBTO sent terms of reference to request proposals to provide for the technical requirements for the measurements in Kuwait. The scientific partner KISR offered to provide all requirements for performing the measurements. This included the measurement room, electrical power, and helium gas. 


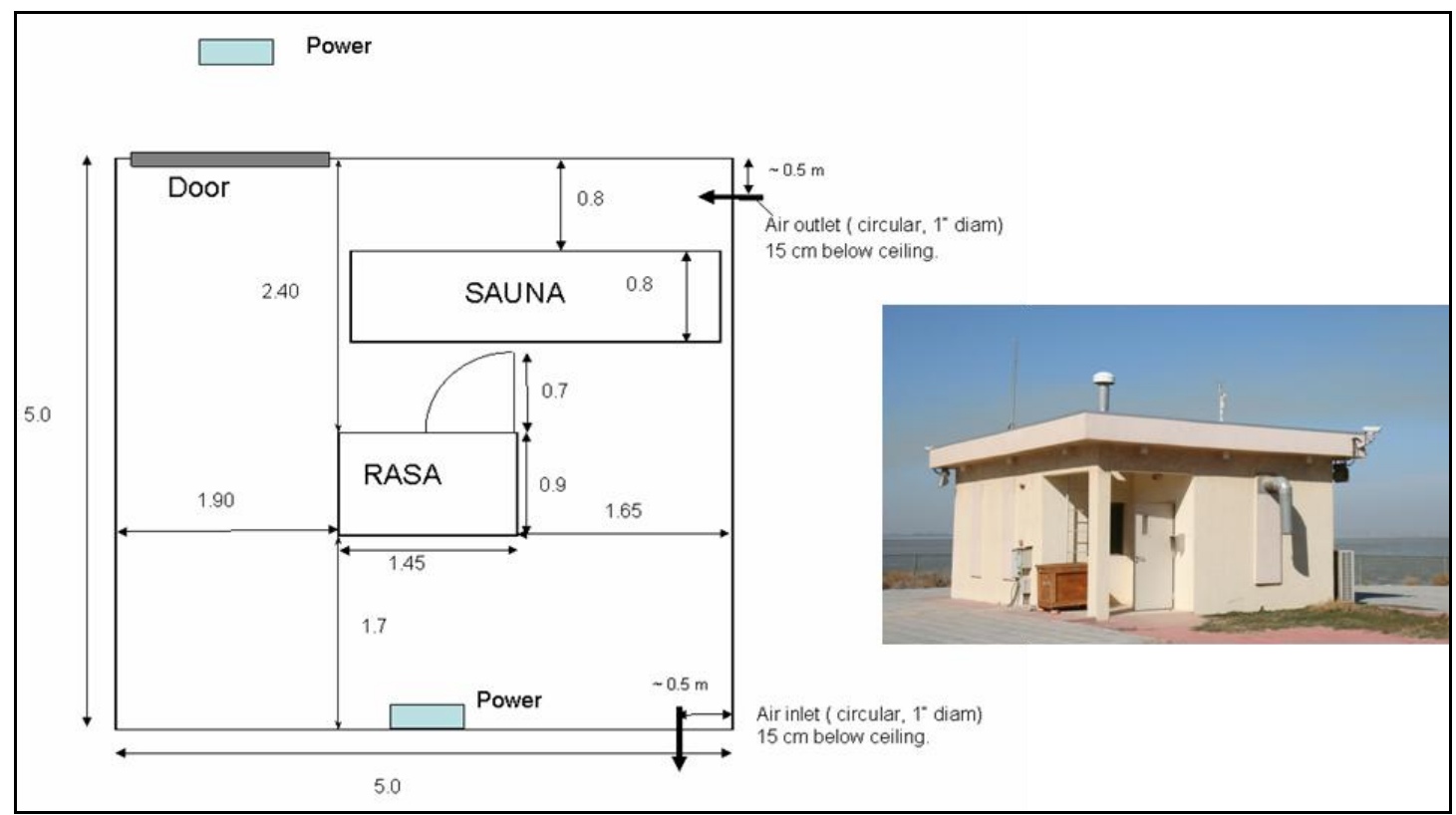

Figure 2.9. A Schematic of the Station Indicating the Position of the SAUNA and the RASA Particulate System. The photo shows the station building at the shore of the Persian Gulf.

\subsubsection{Deployment and Operation of the Radioxenon System}

The measurement campaign in Kuwait started on September 5 and ended on December 1, 2008, using the FOI SAUNA radioxenon system. The staff from KISR was very supportive to make this campaign a success. Measurements were made automatically on-site with the SAUNA; samples did not need to be shipped offsite for measurement.

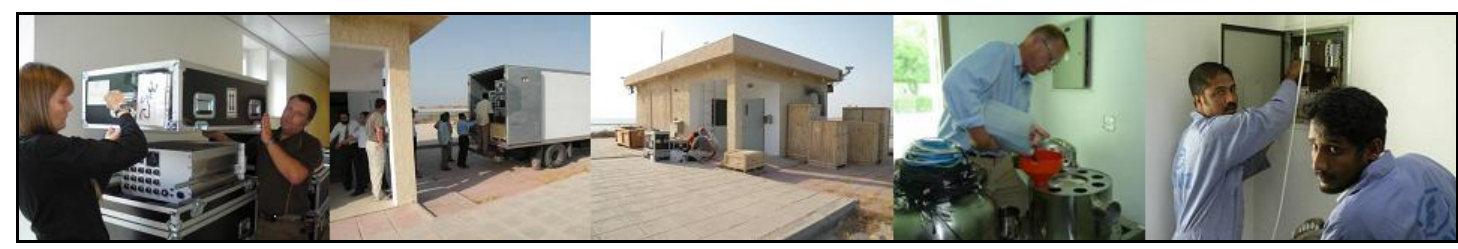

Figure 2.10. From Left to Right: Packing of the SAUNA in Stockholm, delivery at the station the boxes in front of the station, filling of the lead shields and making electrical connections.

The FOI SAUNA system was delayed at Kuwaiti Customs, but with the help of senior staff at KISR it was finally released. The import of the calibration sources and stable xenon gas was also delayed due to problems with the local carrier. A radioactive calibration source was borrowed from KISR and calibration of the SAUNA's gas chromatograph was postponed.

During operations, sand accumulated in the fan filters of the SAUNA, which required a regular filter cleaning. Further, there were gas chromatograph software problems from September 12 to 18, and several technical problems occurred including a broken fan and valve and electronic noise from November 1 to 15 ( Figure 2.11). 


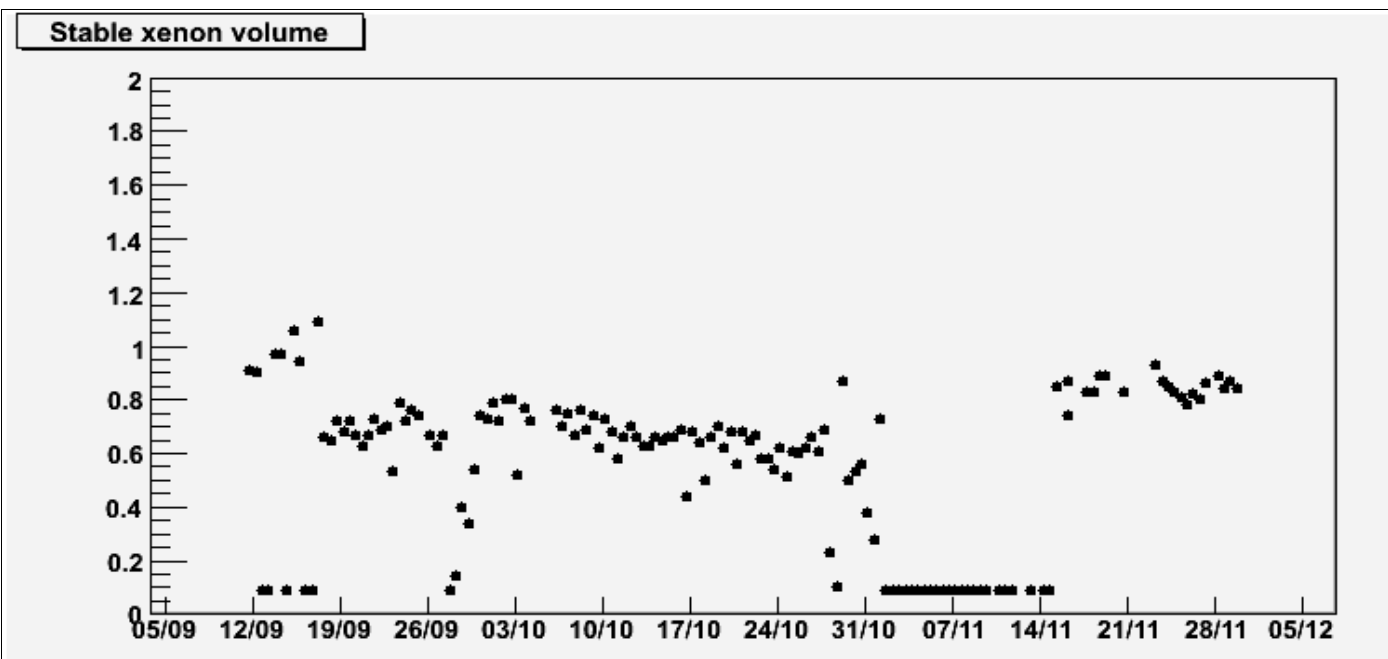

Figure 2.11. The Stable Xenon Collected By the SAUNA Versus Time During the Kuwait Campaign

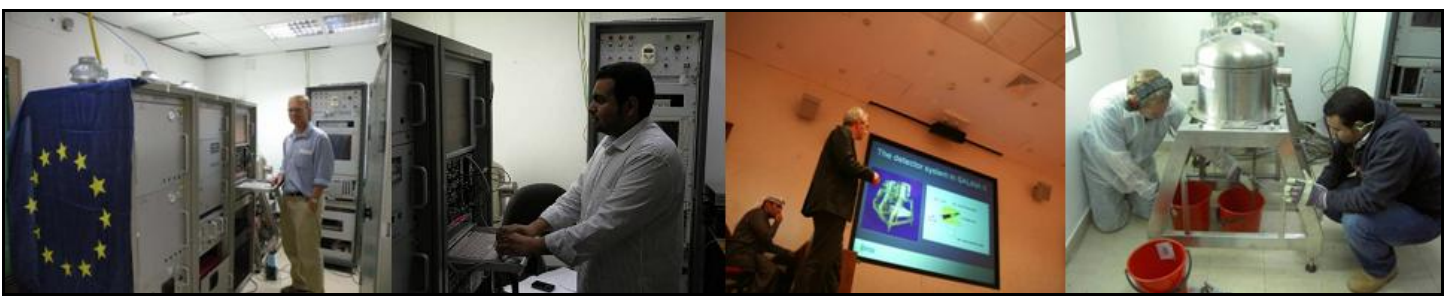

Figure 2.12. From Left to Right: FOI Staff operating the SAUNA, local staff operating the SAUNA, Lectures at the KISR, and Preparing the SAUNA for Return

\subsubsection{Overview of Results}

The system produced 113 samples with a stable xenon volume large enough to be analyzed with the SAUNA system $\left(>0.3 \mathrm{~cm}^{3}\right)$. In general, we observed the radioxenon concentration levels to be low in Kuwait City during our measurement period. However, low but clearly detected ${ }^{133} \mathrm{Xe}$ levels were measured in over 40 samples, and ${ }^{131 \mathrm{~m}} \mathrm{Xe}$ was detected on at least five occasions (Figure 2.13). No clear detections of ${ }^{133 \mathrm{~m}} \mathrm{Xe}$ or ${ }^{135} \mathrm{Xe}$ were observed during the measurement campaign.

The highest observed ${ }^{133} \mathrm{Xe}$ level was $0.83 \pm 0.11 \mathrm{mBq} / \mathrm{m}^{3}$, and the mean concentration was 0.17 $\mathrm{mBq} / \mathrm{m}^{3}$ (Table 2.3). The observed ${ }^{133}$ Xe plumes were broad, ranging over several days to a week, which could indicate remote sources of radioxenon.

Table 2.3. Statistical Overview of the Results

\begin{tabular}{ccccc}
\hline $\mathrm{mBq} / \mathrm{m}^{3}$ & ${ }^{131 \mathrm{~m}} \mathrm{Xe}$ & ${ }^{133 \mathrm{~m}} \mathrm{Xe}$ & ${ }^{133} \mathrm{Xe}$ & ${ }^{135} \mathrm{Xe}$ \\
\hline Minimum concentration & -0.093 & -0.11 & -0.19 & -0.88 \\
Maximum concentration & 0.92 & 0.1 & 0.83 & 0.67 \\
Median concentration & 0.051 & 0.014 & 0.11 & 0.049 \\
Mean concentration & 0.063 & 0.013 & 0.17 & -0.033
\end{tabular}




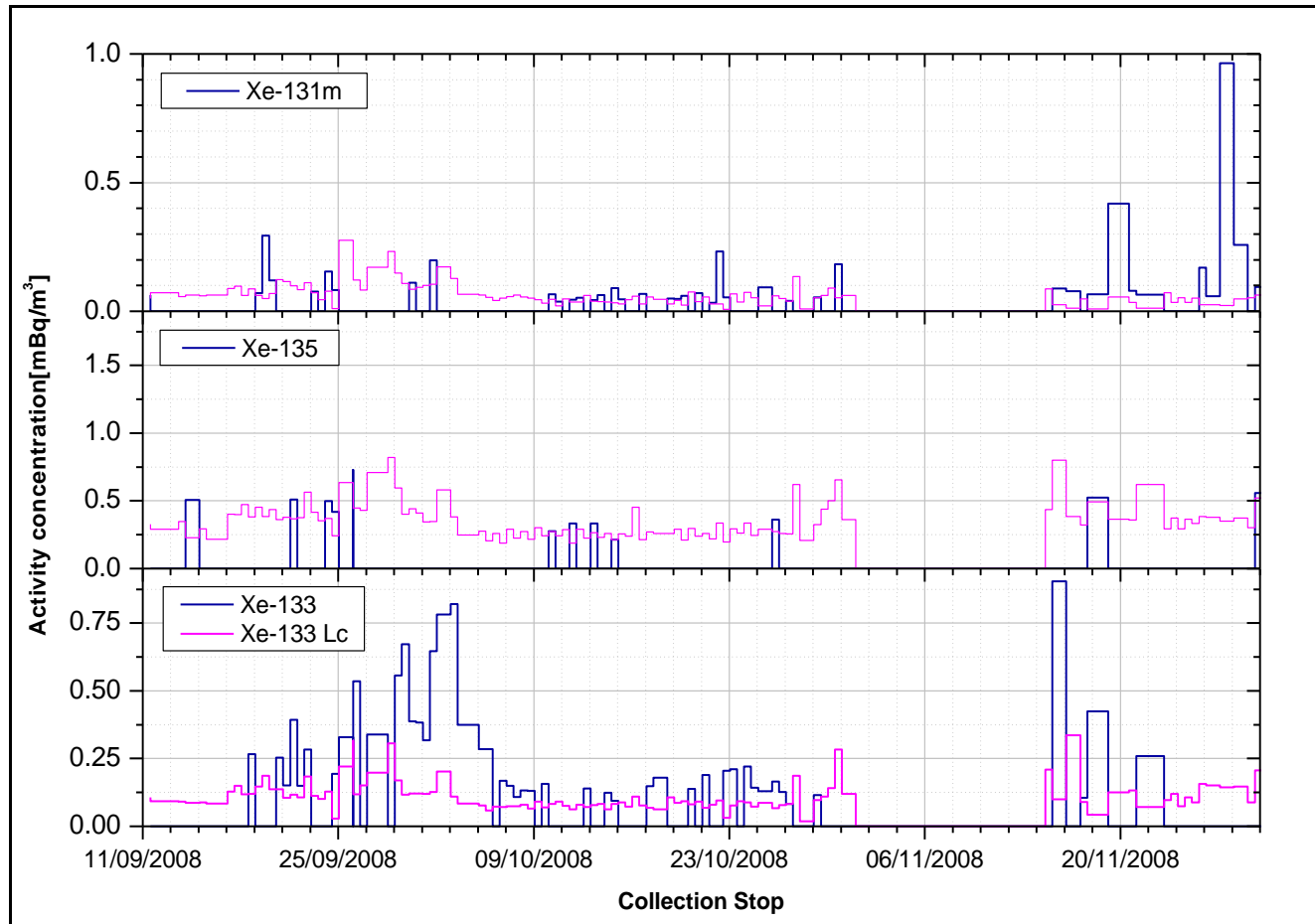

Figure 2.13. Time Series of the Radioxenon Isotopes 131m, 133 and 135

As shown in Figure 2.14, ${ }^{133} \mathrm{Xe}$ and ${ }^{131 \mathrm{~m}} \mathrm{Xe}$ concentrations appear to be anti-correlated: in 36 samples ${ }^{133} \mathrm{Xe}$ is present (i.e., value is larger than $\mathrm{L}_{\mathrm{c}}$ ) but there is no ${ }^{131 \mathrm{~m}} \mathrm{Xe}$; in 29 samples ${ }^{131 \mathrm{~m}} \mathrm{Xe}$ is present but there is no ${ }^{133} \mathrm{Xe}$; and only in 11 samples are both nuclides present. This indicates that ${ }^{133} \mathrm{Xe}$ and ${ }^{131 \mathrm{~m}} \mathrm{Xe}$ originate from different sources. 


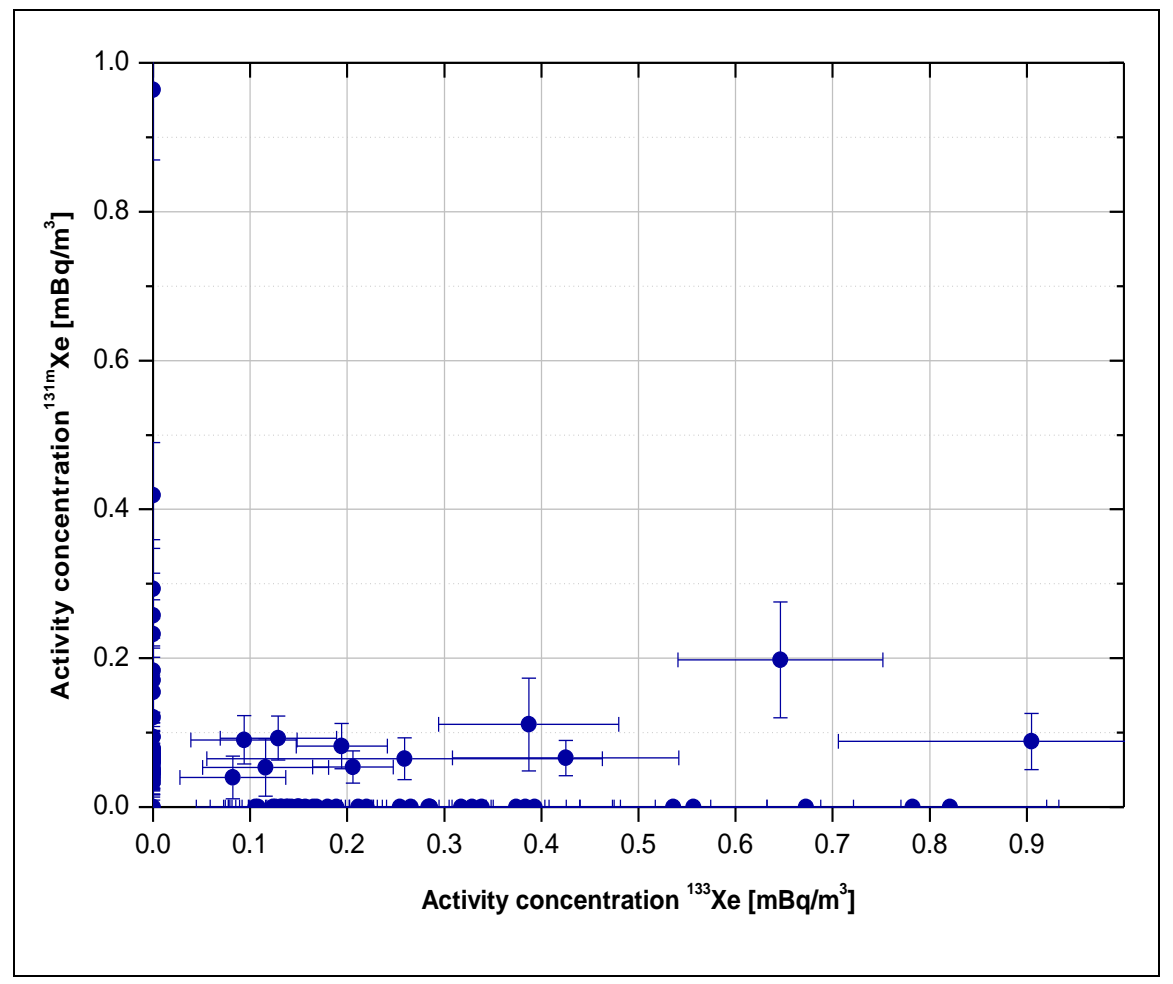

Figure 2.14. Correlation Between ${ }^{133} \mathrm{Xe}$ and ${ }^{131 \mathrm{~m}} \mathrm{Xe}$

Before the Kuwait campaign was initiated, atmospheric network forecast calculations for 10 days were performed using 2006 meteorological data. The Possible Source Region (PSR), which is a map that depicts the area or areas that best fit detections in several samples that can be assumed to belong to the same event (Wotawa et al., 2003; Becker et al., 2007), is shown in Figure 2.15. After the campaign, the same calculations were performed but for a 21-day period. Calculated with the real meteorological data for the time period the campaign took place, Figure 2.16 shows that Kuwait City monitored the near and middle east, Northern Africa, and later (November) Europe, possibly extended to the Northern United States and South-East Canada, where the Chalk River Laboratory is situated. 


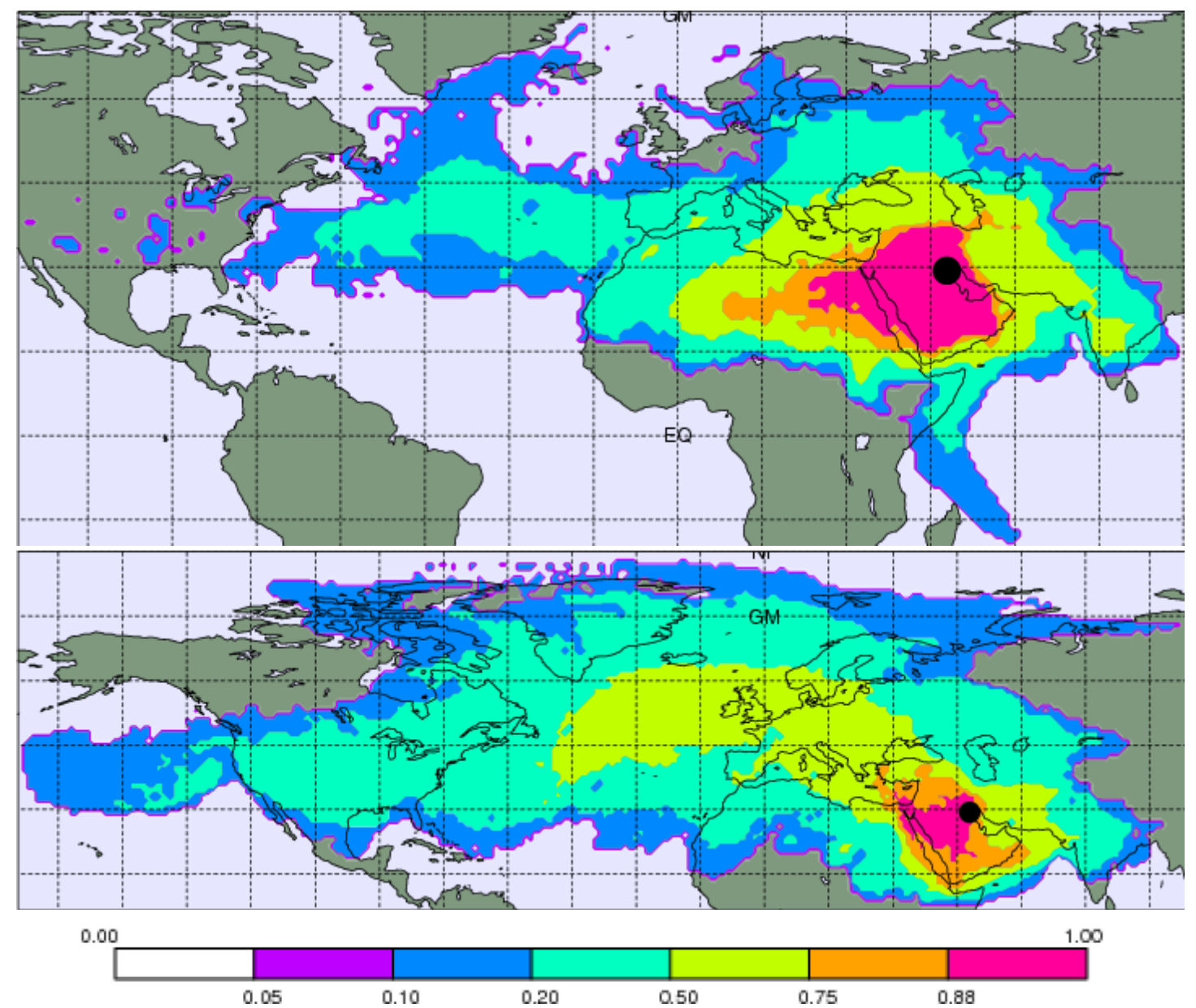

Figure 2.15. Projected Network Coverage for the Kuwait Station With 2006 Standard Source Receptor Fields (the Scale Indicates the PSR Correlation). The upper graph is calculated for October, and the lower one is calculated for November.

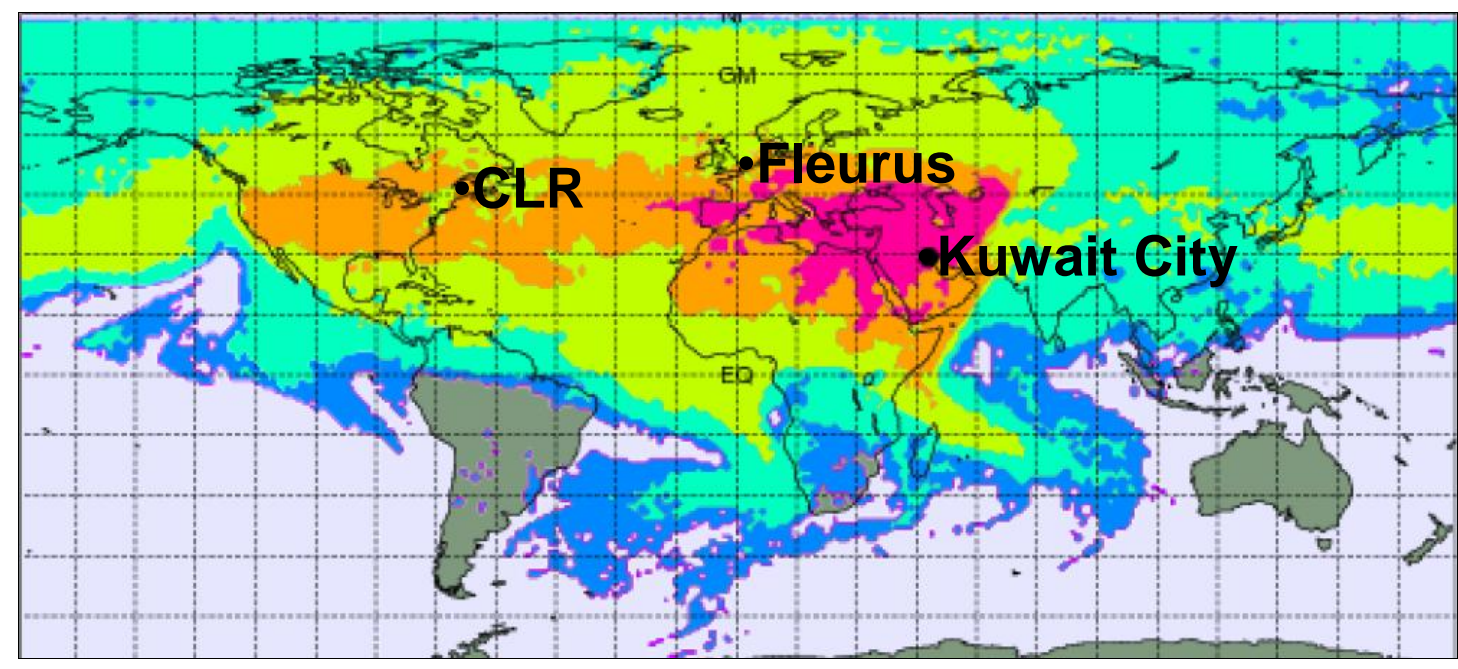

Figure 2.16. Actually Encountered Network Coverage for Kuwait with SRS Data Pertaining to Measurements 


\subsubsection{Conclusions for the Kuwait Campaign}

Radioxenon measurements were performed by FOI and PNNL staff at the IMS radionuclide station KWP40 in Kuwait City between September 11 and November 30, 2008, using a SAUNA-II system. In total, 113 12-hour samples with a stable xenon volume large enough to be analyzed with the SAUNA system $\left(>0.3 \mathrm{~cm}^{3}\right)$ were measured. Low but clearly detected ${ }^{133} \mathrm{Xe}$ levels were measured in over 40 samples, and ${ }^{131 \mathrm{~m}} \mathrm{Xe}$ was detected on at least five occasions. There does appear to an anti-correlation between ${ }^{133} \mathrm{Xe}$ and ${ }^{131 \mathrm{~m}} \mathrm{Xe}$.

Analysis of atmospheric transport models indicates that the main sources for ${ }^{133} \mathrm{Xe}$ are located in Europe, while the ${ }^{131 \mathrm{~m}} \mathrm{Xe}$ could also be of more local origin. The measurements further show that Northern Africa had no larger xenon emissions during the periods of coverage. No clear detections of ${ }^{133 m} \mathrm{Xe}$ or ${ }^{135} \mathrm{Xe}$ were observed.

\subsection{The measurements in Mafikeng, South Africa}

\subsubsection{Site Survey}

Several potential sites were visited in two areas in South Africa, Cape Town (January 21-25 2008) and Johannesburg (January 28 - February 2, 2008).

At Johannesburg, the NTP Radioisotopes Ltd. facility in Pelindaba, Pretoria and North-West University in Mafikeng were visited. At the recommendation of the South African Nuclear Energy Corporation Ltd. (NECSA) in Pelindaba, it was decided the measurements would be done in September 2008 at the North-West University in Mafikeng, situated $250 \mathrm{~km}$ east of Pelindaba. 


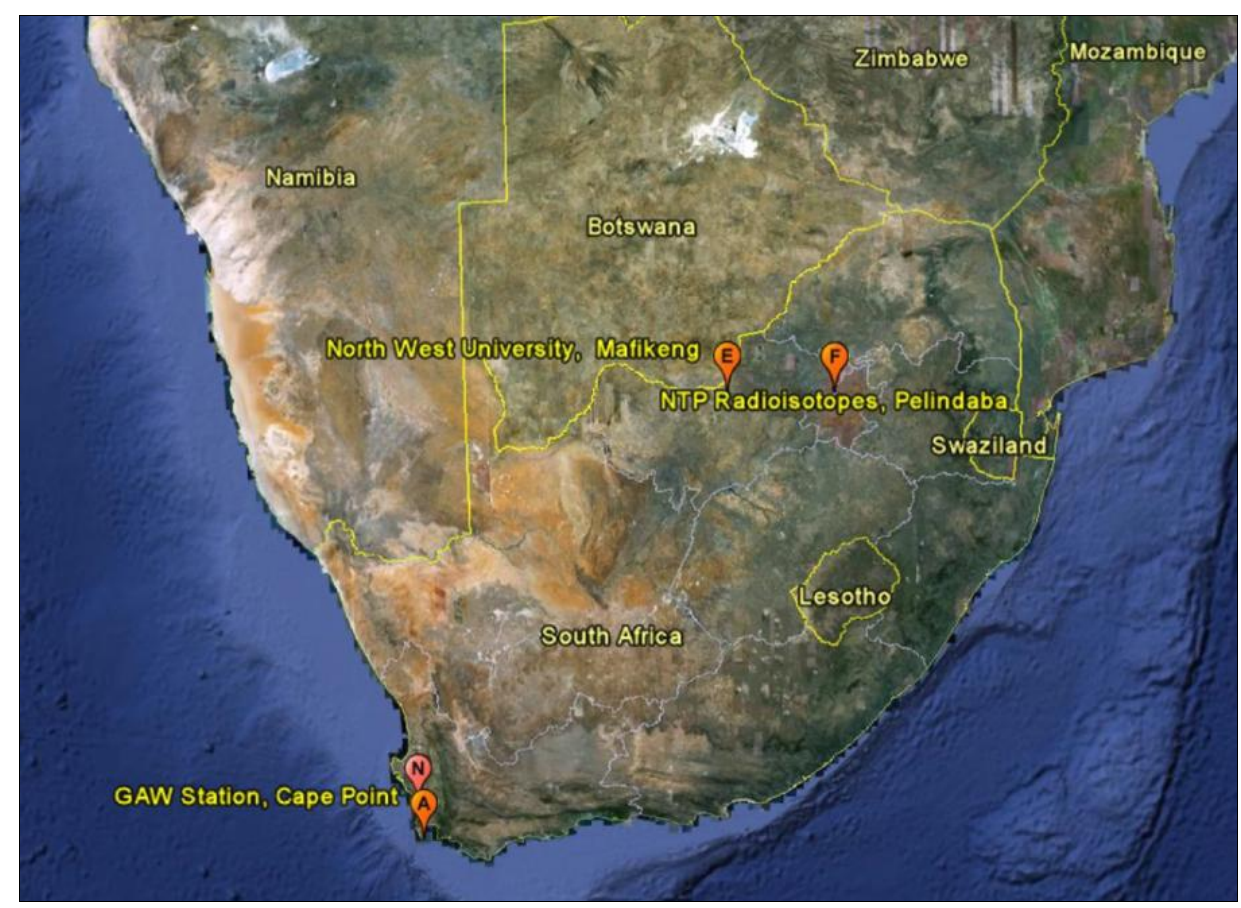

Figure 2.17. An Overview of the South African Sites. N: Nuclear power plant Koeberg, A: Global Atmospheric Watch station, E: Mafikeng Campus of North-West University, F: Nuclear Site of Pelindaba (including NTP and NECSA).

\subsubsection{Local Partners}

The local partners for these measurements were the Centre for Applied Radiation Science and Technology (CARST), North-West University, Mafikeng campus and NECSA, Pelindaba.

\subsubsection{Site Preparations}

The North-West University scientific partner provided all requirements for our measurements. This included the measurement room with air-conditioning and electrical power. The helium gas was purchased locally.

\subsubsection{Deployment and Operation of the Radioxenon System}

Between November 10 and December 22, 2008, radioxenon was measured continuously on-site with a U.S. SAUNA-II radioactive xenon sampling and measurement system (sponsored by DoD/SMDC/PNNL) at CARST at the Mafikeng campus of the North-West University, South Africa, situated $250 \mathrm{~km}$ west of Pelindaba. 


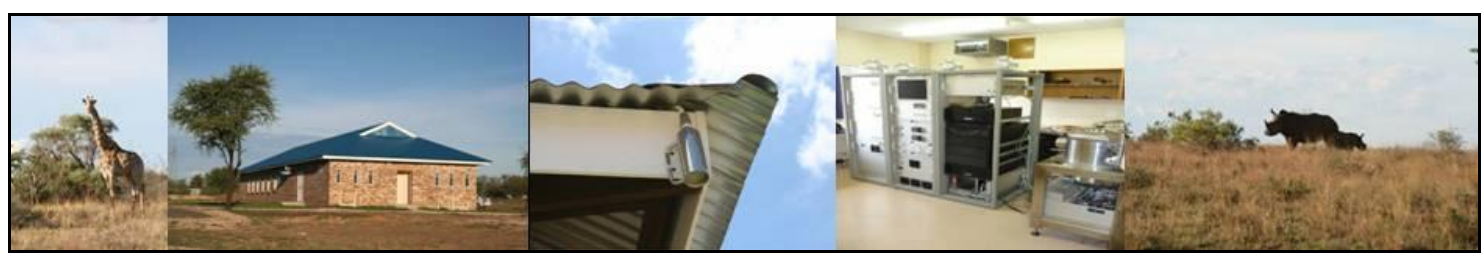

Figure 2.18. The Mafikeng Site Showing the Building Where the Equipment was Deployed, the Inlet of the SAUNA, and the SAUNA System Inside the Building, Framed by Local Wildlife

The CTBTO provided a daily update of the Pelindaba stack's forward plume predictions and calculated field-of-regards (FORs) for each sample.

\subsubsection{Overview of Results}

NTP Radioisotopes Ltd., located in Pelindaba, South Africa is the world's fourth largest RPF and the "backdrop" for our measurements. The only other facilities known to emit any radioxenon on the African continent south of the Equator are the small nuclear power plant of Koeberg, located $1300 \mathrm{~km}$ southwest near Cape Town and a small research reactor in the Democratic Republic of Congo, located $2700 \mathrm{~km}$ northwest of Pelindaba. We expect that RPF source is likely to be very dominant with respect to xenon emission. In fact, during initial visits to the site, local operators of the CTBTO laboratory at Pelindaba had indicated to that radioxenon from the nearby RPF were a major source of background in their highpurity germanium detection system used for measuring particulate filers for the IMS. Therefore we presume that NTP is a single point source, which is a unique situation because all other large RPFs worldwide are situated in regions surrounded by many other nuclear facilities.

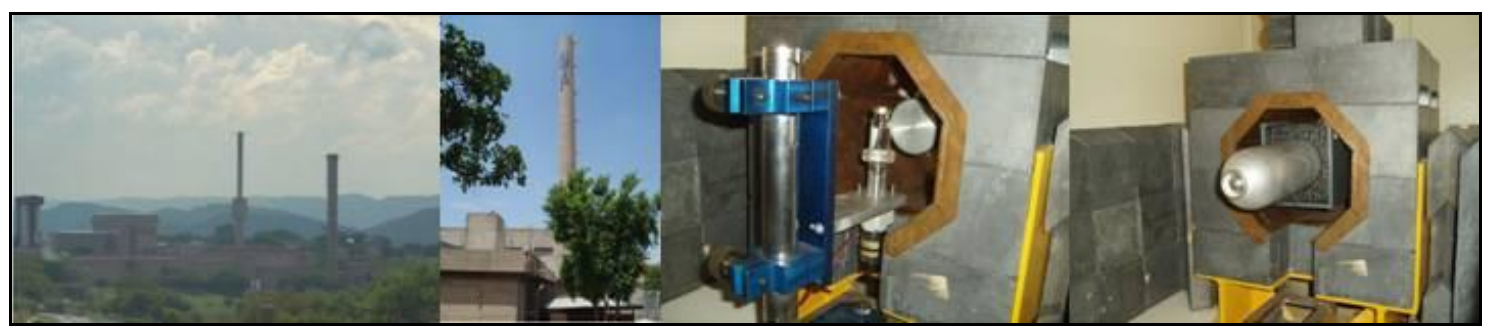

Figure 2.19. From Left to Right: the Pelindaba Facility, the Stack from NTP, Calibrating the HP Ge Detector and the Aluminium Bottle with the Stack Sample in Front of the Detector.

Fifty-six 12-hour samples were measured in Mafikeng with the SAUNA-II detection system. Fiftyfive samples contained ${ }^{133} \mathrm{Xe}$ with values between 0.11 and $27.1 \mathrm{mBq} / \mathrm{m}^{3}$. Eleven samples contained ${ }^{135} \mathrm{Xe}$, and three samples contained ${ }^{133 \mathrm{~m}} \mathrm{Xe}$. In none of the samples was ${ }^{131 \mathrm{~m}} \mathrm{Xe}$ detected. 


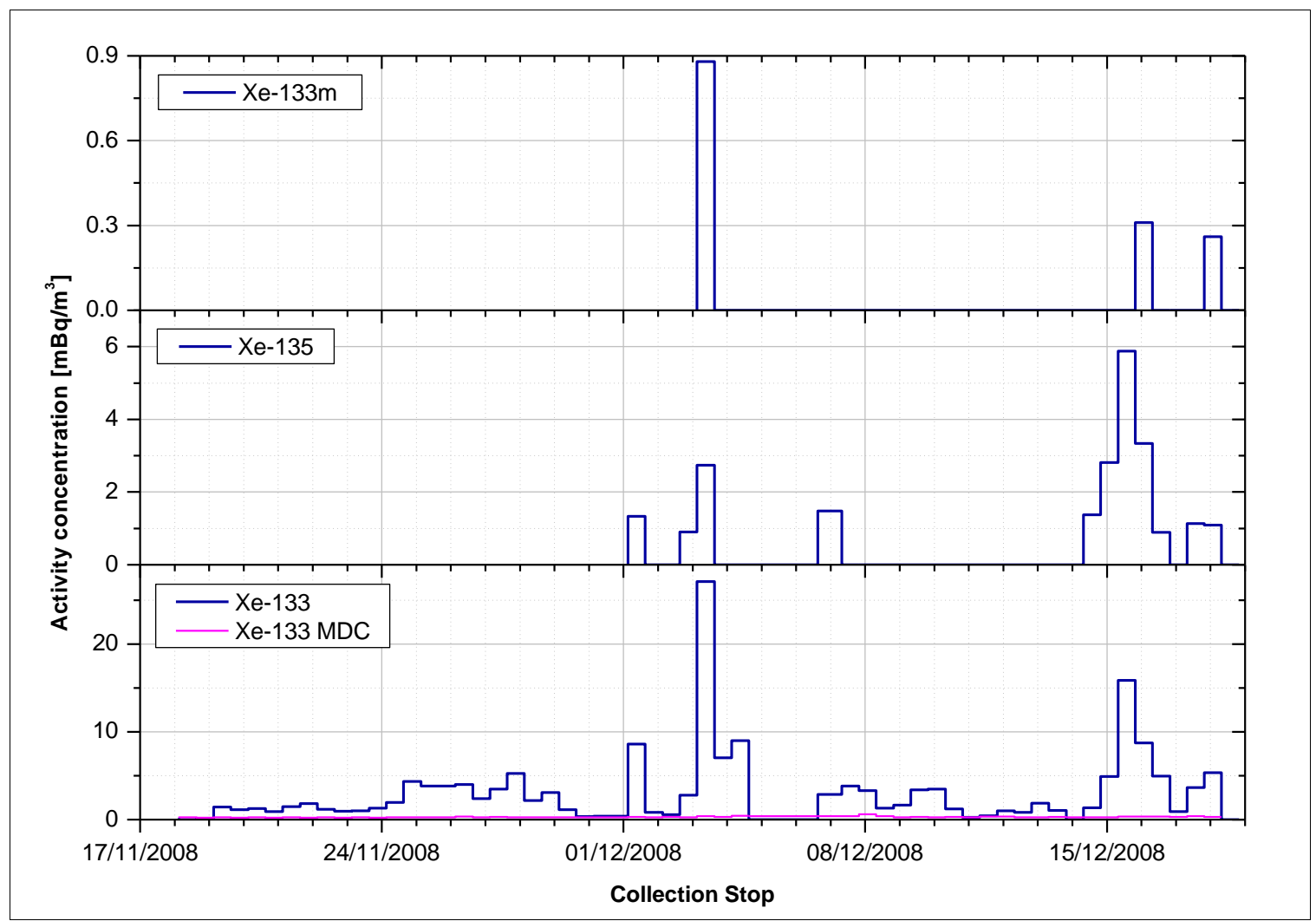

Figure 2.20. Time Series of the Radioxenon Isotopes 131m, 133m and 135

The "Webgrape" atmospheric transport model developed by the CTBTO was applied to identify the possible source region of the measurements presented in Figure 2.20. The example in Figure 2.21 shows the three measurements from December 2 - 3. With a correlation of $0.9-1.0$ (orange area), the air from these measurements in Mafikeng originated from the Pelindaba area. This method clearly identifies the Pelindaba facility as the possible source of the radioxenon detections in Mafikeng. Using the Webgrape result, a release of $1-10 \times 10^{12} \mathrm{~Bq} /$ day can be estimated. This number is consistent with estimates given by NTP staff.

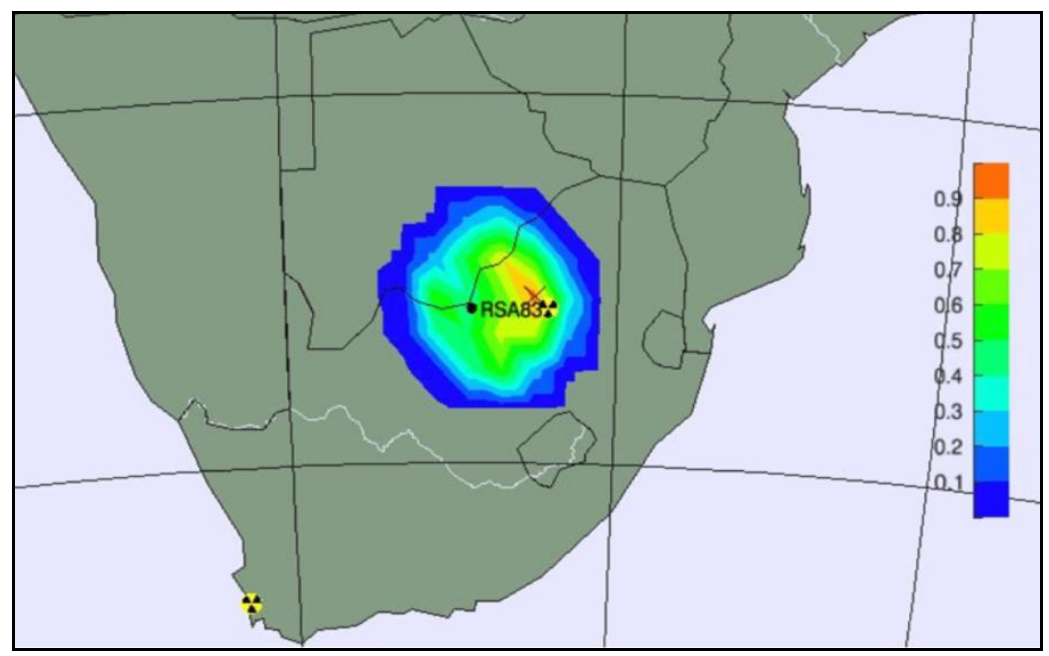

Figure 2.21. The Webgrape Result for the Three Measurements from December 2-3 
Before the campaigns were initiated, atmospheric network forecast calculations for 10 days were performed using 2007 meteorological data. The Possible Source Regions are shown in Figure 2.22. After the campaign, the same calculations were performed but for a 21-day period with meteorological data for the time of the campaign (Figure 2.23). As calculated, the Mafikeng air samples frequently covered the Pelindaba area.

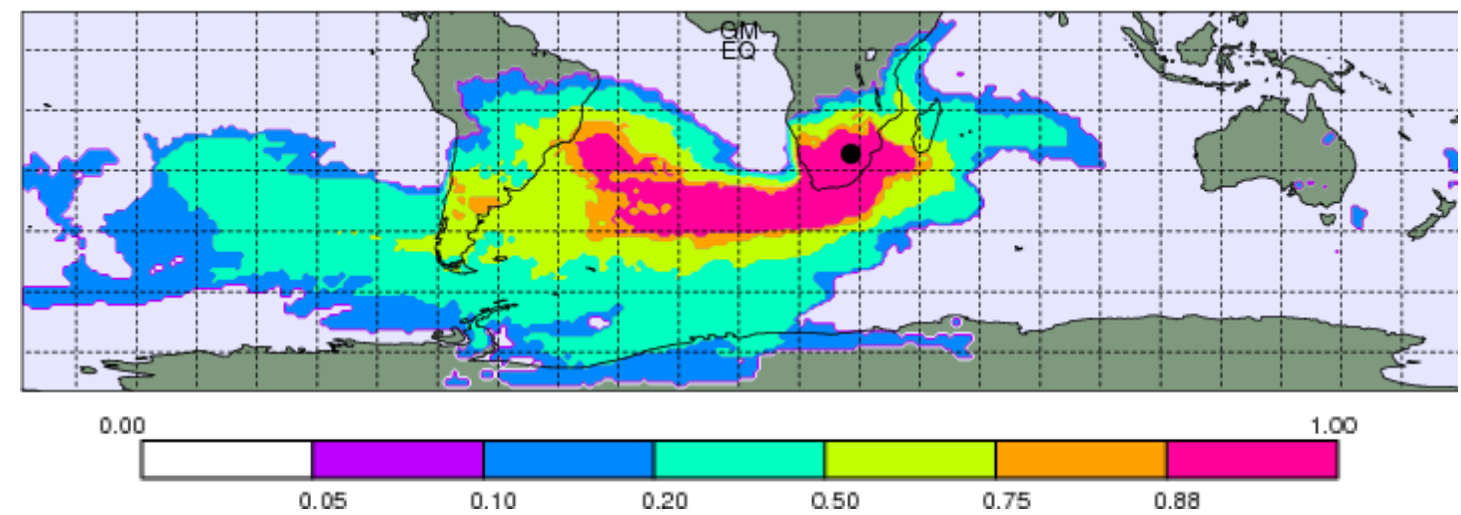

Figure 2.22. Projected Network Coverage for the Mafikeng Station with 2007 SRS Fields (the scale indicates the PSR correlation).

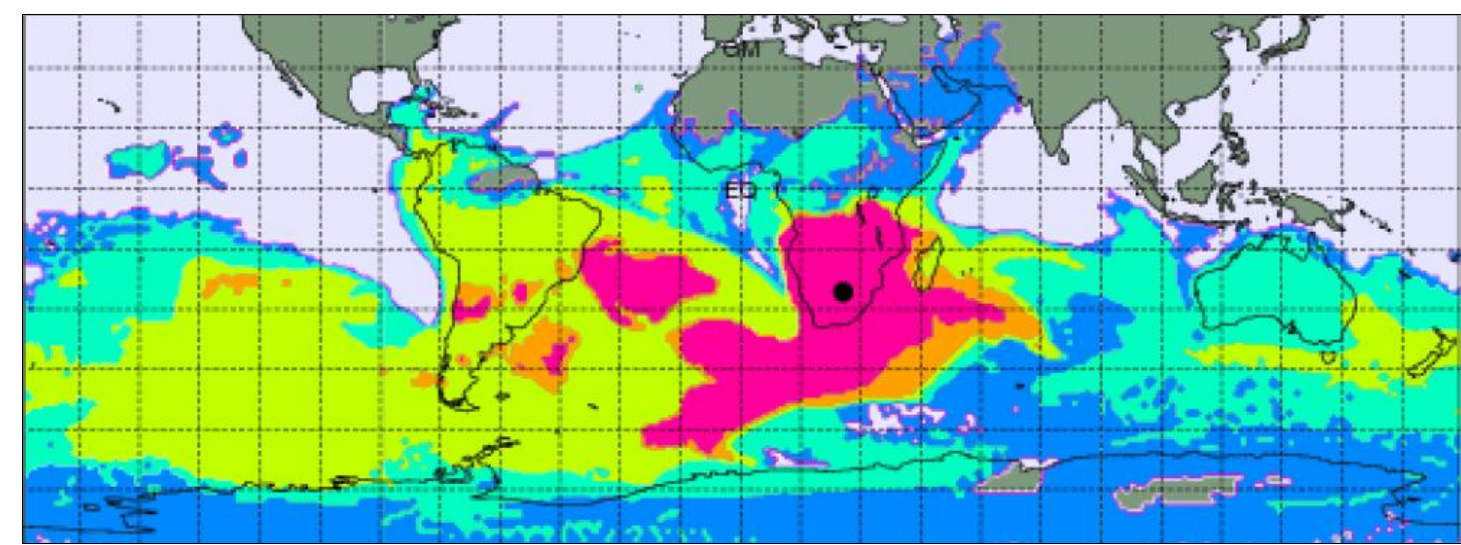

Figure 2.23. Actually Encountered Network Coverage for Mafikeng with SRS Data Pertaining to Measurements.

In parallel to the Mafikeng campaign, stack samples were taken at the NTP facility almost daily, when the dose rate in the stack showed a peak shortly after a ${ }^{99}$ Mo production run. Samples were immediately measured with a high-purity germanium gamma detector at the local laboratory of NECSA. To determine the concentration of radioxenon that might be expected and predict the theoretical isotopic ratios, irradiation of highly enriched uranium (HEU) targets typical for the NTP targets was simulated for one example. The simulation tool Nuclear Analysis 2.0 - Decay and Irradiation Software with nuclear data from ENDF/B-VII.0 was used. 
Table 2.4. Parameters Used for the Calculations of the Radioxenon Inventory of the NTP Facility (IAEA, 1989; Le Roux, 1991; Ball, 1999)

\begin{tabular}{cc}
\hline Neutron Flux $\left(\mathrm{n} / \mathrm{cm}^{2} \mathrm{~s}\right)$ & $1.5 \times 10^{14}$ \\
\hline Irradiation time (hours) & 168 \\
Initial Isotope Inventory per target (grams) & 7.15 \\
${ }^{235} \mathrm{U}$ & 8.74 \\
${ }^{238} \mathrm{U}$ & 26.46 \\
${ }^{27} \mathrm{Al}$ & 12 \\
Number of targets irradiated & 20 \\
Cooling time after irradiation (hours) & 1 \\
Dissolution time (hours) &
\end{tabular}

Figure 2.24 shows the three samples measured at Mafikeng that contained the three isotopes ${ }^{133 \mathrm{~m}} \mathrm{Xe}$, ${ }^{133} \mathrm{Xe}$ and ${ }^{135} \mathrm{Xe}$ (in blue). The measurements of the stack samples collected in parallel to the Mafikeng field campaign are represented in green. The simulation (black curve) covers all data points well.

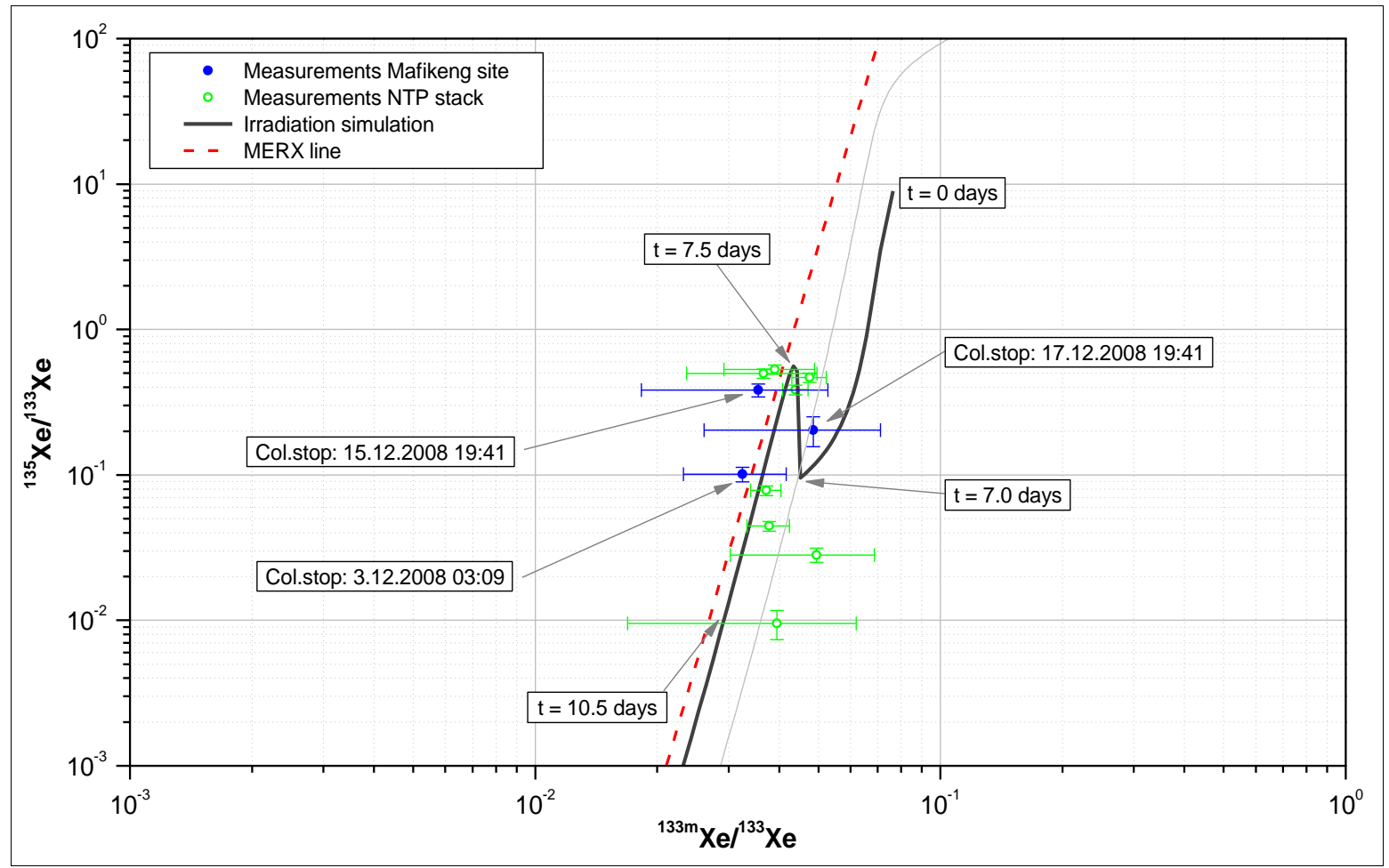

Figure 2.24. The Three-isotopic Graph of the Simulation of Radioxenon Isotopes in a HEU Target Irradiated with the Parameters Common for the NTP Facility. Red: discrimination line, blue: environmental samples, green: stack samples. 


\subsubsection{Conclusion for the Mafikeng Campaign}

During one month of operation, the measured radioxenon content of the sampled air in Mafikeng varied between $0-27 \mathrm{mBq} / \mathrm{m}^{3}$ with a mean value of $3.24 \mathrm{mBq} / \mathrm{m}^{3}$ for ${ }^{133} \mathrm{Xe}$. The relatively high peak values are most probably due to releases from the RPF in Pelindaba, $250 \mathrm{~km}$ east of Mafikeng.

This measurement campaign shows the need to understand local conditions, both in terms of potential sources nearby and of meteorology, to be able to distinguish such a RPF signal from a nuclear explosion signal.

The stack measurements correspond to a daily release of approximately $1-10 \times 10^{12} \mathrm{~Bq}$. This is consistent with the Mafikeng measurements and with typical release rates published for this type of facility and estimates from NTP staff. It is well below exposure guidelines and thus not dangerous to the public. Compared with the ${ }^{133} \mathrm{Xe}$ produced directly after dissolution $\left(6.8 \times 10^{14} \mathrm{~Bq}\right)$, this shows that around $0.1-1 \%$ of the maximum produced ${ }^{133} \mathrm{Xe}$ is released into the atmosphere.

On the other hand, this amount is expected to be high enough to increase the radioxenon background in wide regions around the facility and has a potential impact on the monitoring capability of the highly sensitive IMS xenon monitoring systems.

The simulated radioxenon isotopical ratios also fit well with the long-distance measurements in Mafikeng and with the local stack measurements. This indicates that no other processes took place at the facility that could influence the isotopic composition, and therefore, the source term is now well understood. However, the fact that these measurements are consistent with theoretical predictions are not consistent with the results from IRE - these processes seem to be much simpler. This could have to do with the differences in the type of dissolution chemistry used by NTP and IRE, however more information is clearly needed.

\subsection{The Measurements in Cape Point, South Africa}

\subsubsection{Site Survey}

In the Cape Town South Africa area, a Global Atmospheric Watch (GAW) station at Cape Point, the South Africa Weather Service (SAWS) office at the Cape Town International Airport, the SAWS offices at Stellenbosch, and the iThemba Labs in Faure were visited. After careful study and consideration, it was concluded that technically, logistically, and scientifically the best site among the three is the SAWS GAW station at Cape Point:

- The iThemba Labs site could have hosted the campaign from a technically and logistically point of view. The unknown releases from the isotopic production, however, might have interfered with the very sensitive ultra-low measurement equipment. Therefore, this site was not found adequate from a scientific point of view.

- The SAWS site at Cape Town International Airport could have hosted radioxenon equipment inside a container. The site, however, is situated $10 \mathrm{~km}$ downwind from iThemba Labs. Therefore, the same concerns of the influence of isotopic production also applied here. 
- Technically, logistically, and scientifically the best site was the SAWS GAW station at Cape Point. It had the possibility to host the equipment in an air-conditioned room or to host a container. The site is also safe and easily accessible.

Measurements were planned to be undertaken for 4-6 weeks in August 2008, but the campaign was delayed until early January 2009 due to the time needed to finalize administrative details.

\subsubsection{Local Partner}

The local partner was the South Africa Weather Service (SAWS).

\subsubsection{Site Preparations}

SAWS, the scientific partner, provided all requirements for these measurements. This included the measurement room and electrical power. The helium gas was purchased locally.

\subsubsection{Deployment and Operation of the Radioxenon System}

Between January 16 and February 2, 2009, radioxenon was measured continuously with a SAUNA-II radioactive xenon sampling and measurement system, sponsored by DoD/SMDC/PNNL.

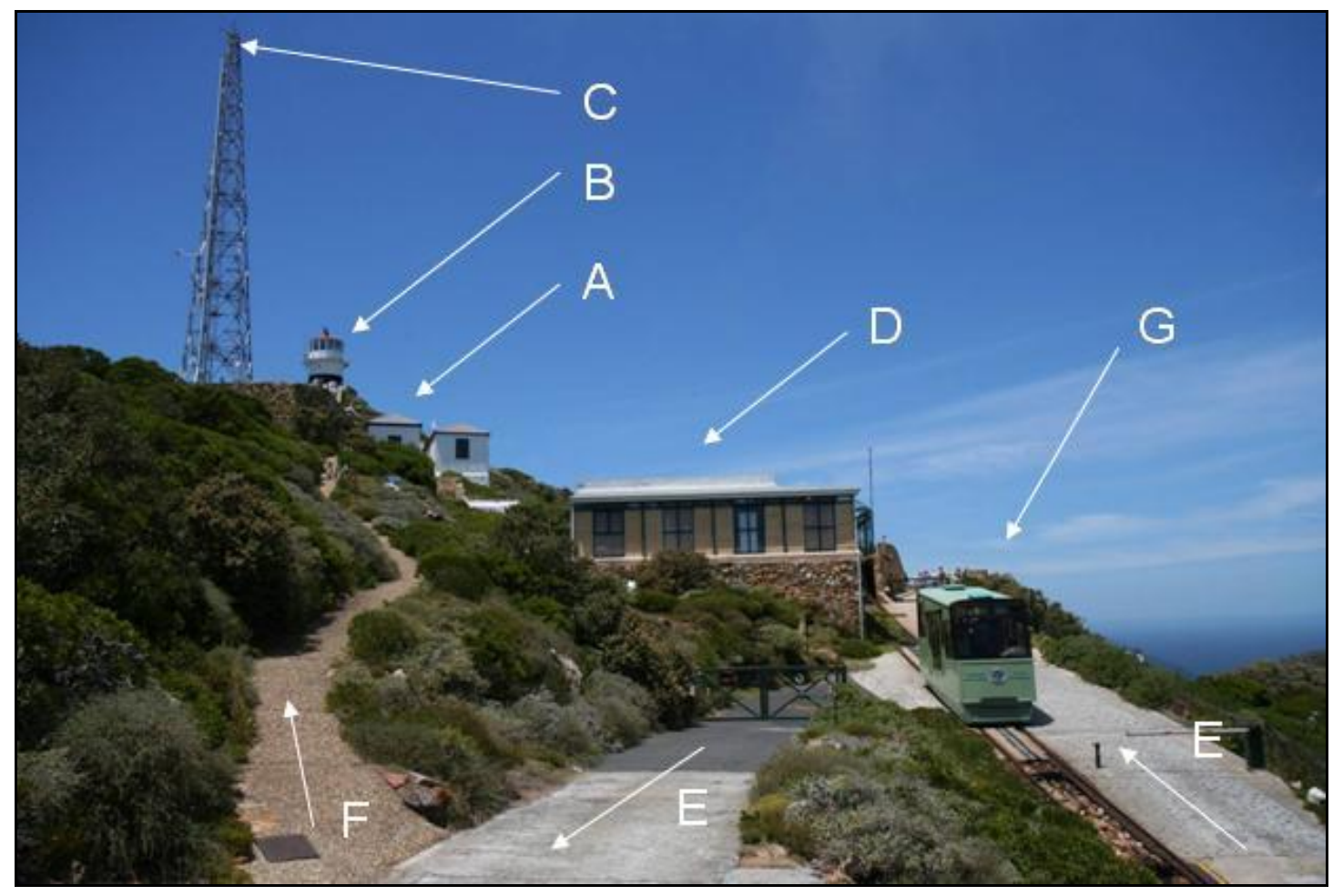

Figure 2.25. The Site in Cape Point. A: GAW Station, B: Old Lighthouse, C: GAW Measurement Tower, D: Funicular Mountain Station, E: Private Car Road, F: Walking Road to the Station, G: Funicular for Tourists. 


\subsubsection{Overview of Results}

During three weeks of operation, no measurable amounts of any of the four CTBT relevant radioxenon isotopes were observed. Figure 2.26 shows a summation of all sampled spectra from the SAUNA system. The arrows indicate known gamma peaks from radon daughters, but it was determined that no appreciable radioxenon could be detected. The $30-\mathrm{keV}$ xenon X-ray region, where the X-rays from the xenon isotopes $131 \mathrm{~m}, 133 \mathrm{~m}$, and 133 were expected, is indicated with a red arrow - no peak was found here either.

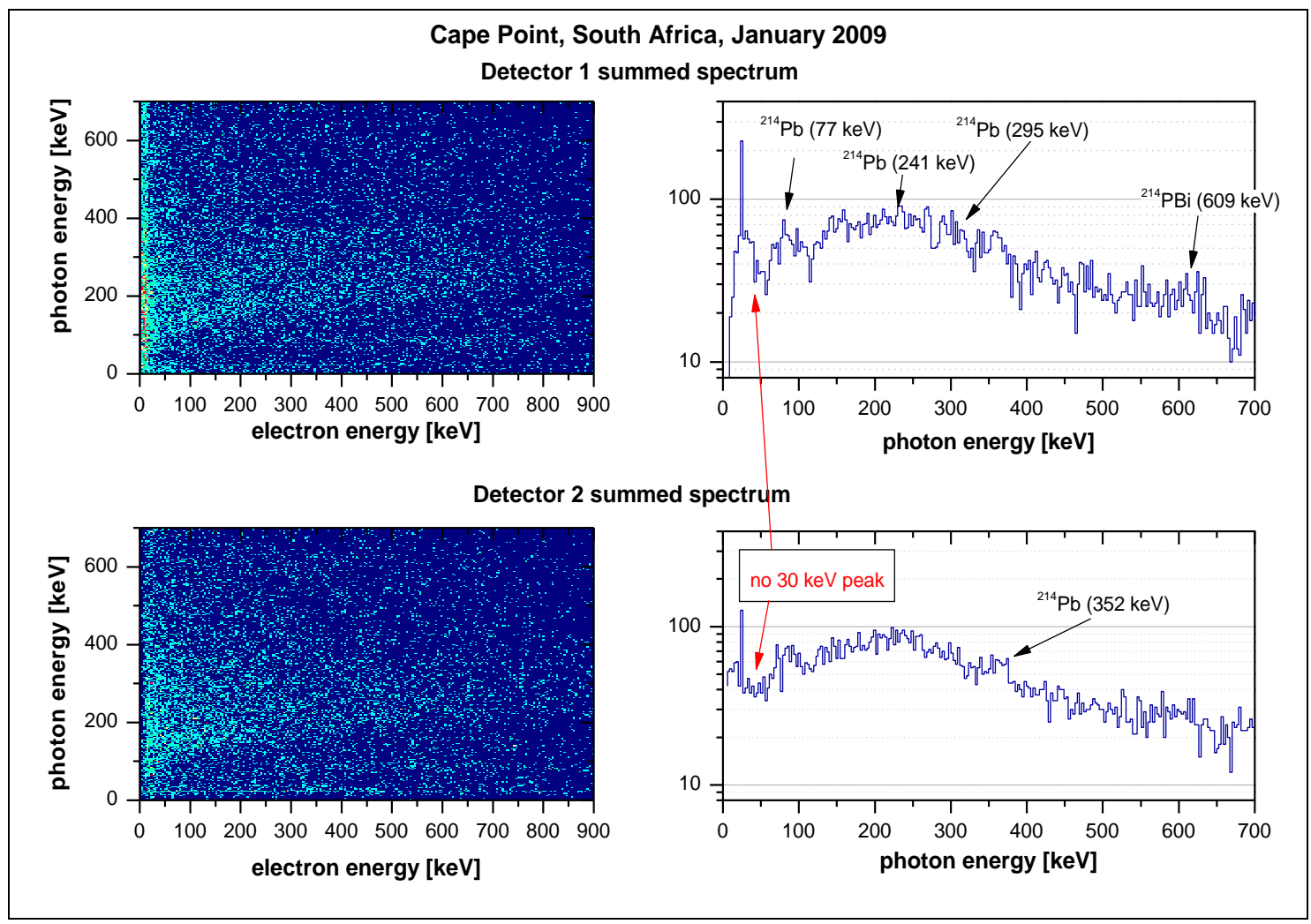

Figure 2.26. Beta-gamma and Gamma Spectra (in coincidence with beta) for the Summed Sample Spectra Measured by Detector 1 (upper two graphs) and Detector 2 (lower two graphs).

Before the campaigns were initiated, atmospheric network forecast calculations for 10 days were performed using 2007 meteorological data (Figure 2.27). After the campaign, the same calculations were performed for a 21-day period (Figure 2.28). It can be concluded that even cleaner oceanic air than was projected was measured in Cape Point. 


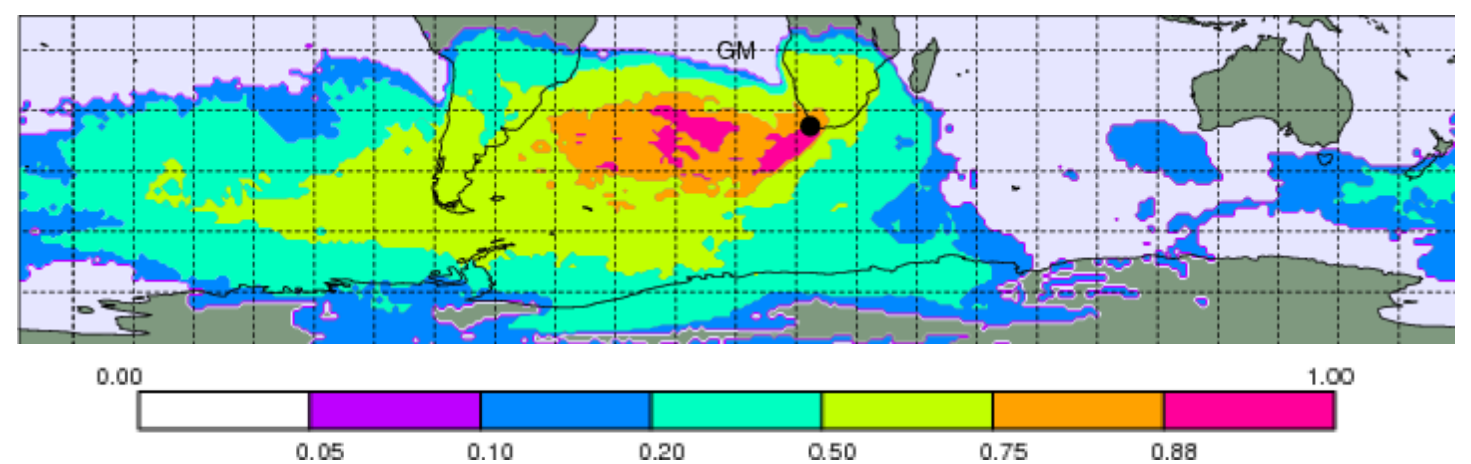

Figure 2.27. Projected Network Coverage for the Cape Point Station with 2007 SRS Fields (the scale indicates the PSR correlation)

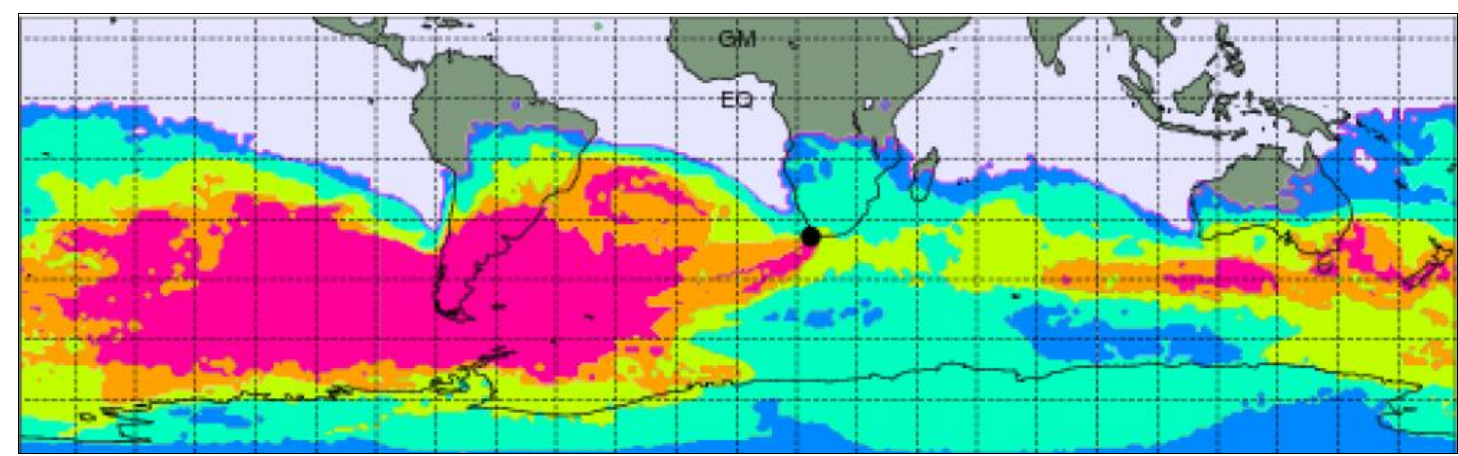

Figure 2.28. Actually Encountered Network Coverage for Cape Point with SRS Data Pertaining to Measurements.

\subsubsection{Conclusion from the Cape Point Campaign}

The meteorological backtracking indicated that all the air that passed the station during the campaign originated from the Southern Atlantic Ocean or from Antarctica, both regions where no radioxenon is to be expected. No evidence of radioxenon could be found, and although this result isn't completely unexpected, it was thought that plumes of radioxenon from the Pelindaba RFP could reach our sampling point on occasion. This effect was not detected, though continual long term measurements would have to be performed to determine if this is the case or not.

\subsection{The Measurements in Thailand}

\subsubsection{Site Survey}

On May 31 - June 6, 2008, a site survey was undertaken at the University of Chang Mai in Chang Mai, Thailand. Radioxenon background measurements were planned for 6 weeks during JanuaryFebruary 2009.

\subsubsection{Local Partner}

The local partner was Plasma and Beam Physics Research Facility, Chang Mai University. 


\subsubsection{Site Preparations}

The measurement location was upgraded to account for high temperature and humidity which could affect SAUNA operations, therefore the air conditioning capacity was increased. There existed the possibility of atmospheric decoupling during the hot season; therefore, the campaign was planned for the January - February period. There was also a back-up site at the Sirindhorn astronomic observatory on the local mountainside.

\subsubsection{Deployment and Operation of the Radioxenon System}

The shipping of the FOI SAUNA equipment from Kuwait was delayed by two months due to difficulties with the transport company between Kuwait and Thailand. The system was eventually flown to Bangkok and transported by truck from Bangkok to Chiang Mai University.

The SAUNA arrived on February 14, 2009 followed by the FOI/CTBTO team on February 16. The system was installed, and the sampling and measuring started on February 26.

The campaign was extended in Chang Mai because the planned Nepal measurement campaign was cancelled. The last sample was then taken on April 30, and dismantling by two people proceeded on May 1-2. Two additional people helped to carry the boxes out of the building. All was packed in three days and later shipped by truck to Bangkok airport for further transport to FOI in Sweden.

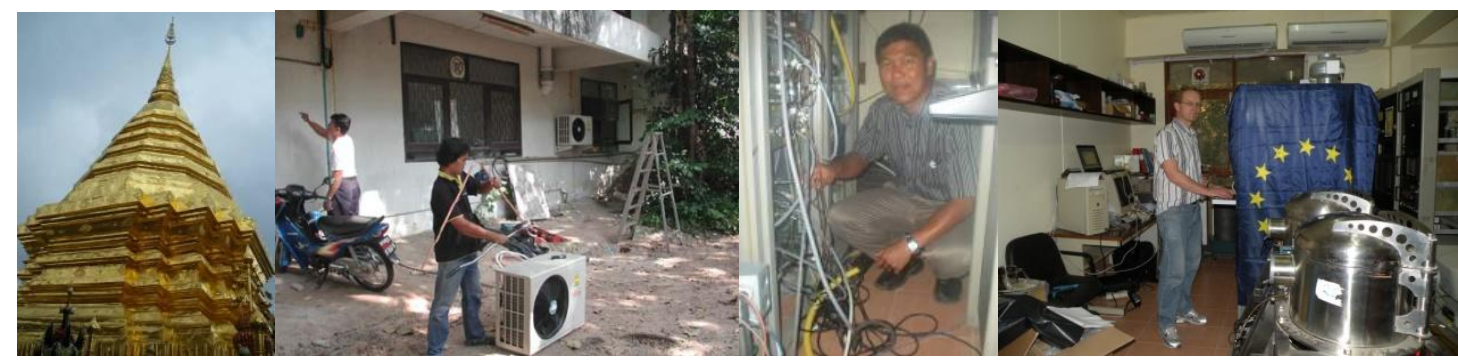

Figure 2.29. From Left to Right: a Local Buddhist Temple, the Installation of the Air-Conditioning, the Setup of the SAUNA, Operating the SAUNA.

The performance of the SAUNA II system is illustrated in Figure 2.30, showing the collected xenon volumes for all samples. There were problems with one of the sampling ovens when a fuse blew sometimes during heating, and unfortunately, this was not discovered during the campaign. Although this affected the sensitivity of the measurements during the campaign, because only half of the normal air xenon was collected, this problem did not impact or affect the calculated concentrations. The electric power in the building was intermittently off for short periods, lasting up to 1.5 hours. An uninterruptible power supply (UPS) system for the SAUNA equipment did, however, guarantee all operation. 


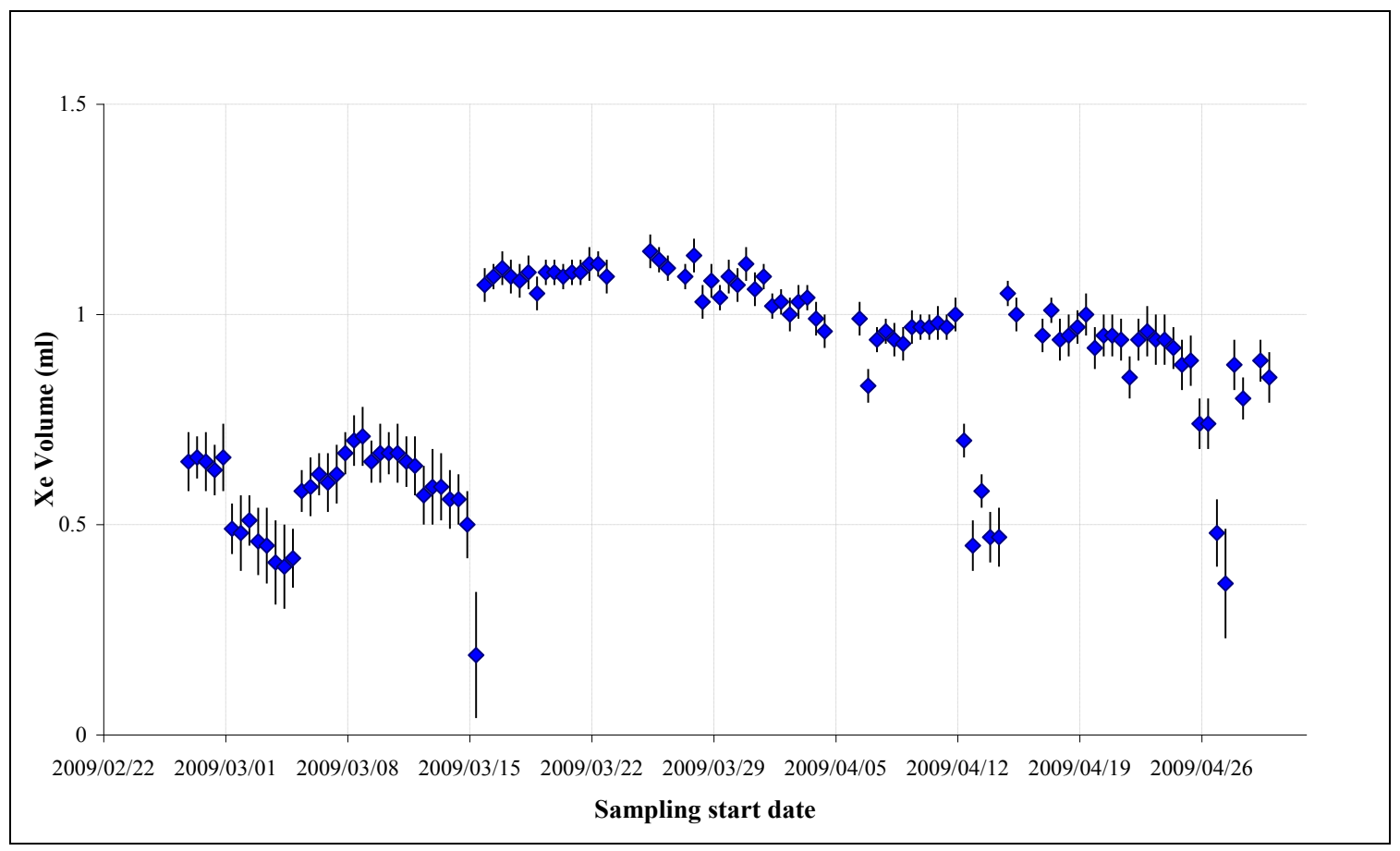

Figure 2.30. The Stable Xenon versus Time During the Thai Campaign.

\subsubsection{Overview of Results}

The activity concentration time series for the two measured isotopes $\left({ }^{131 \mathrm{~m}} \mathrm{Xe}\right.$ and $\left.{ }^{133} \mathrm{Xe}\right)$ are shown in Figure 2.31. Only samples with a xenon volume greater than $0.1 \mathrm{~cm}^{3}$ and with data acquisition times longer than 10,000 seconds are included.

The nuclides ${ }^{133 \mathrm{~m}} \mathrm{Xe}$ and ${ }^{135} \mathrm{Xe}$ had all values below the critical limit and are therefore considered not present for these measurements. 


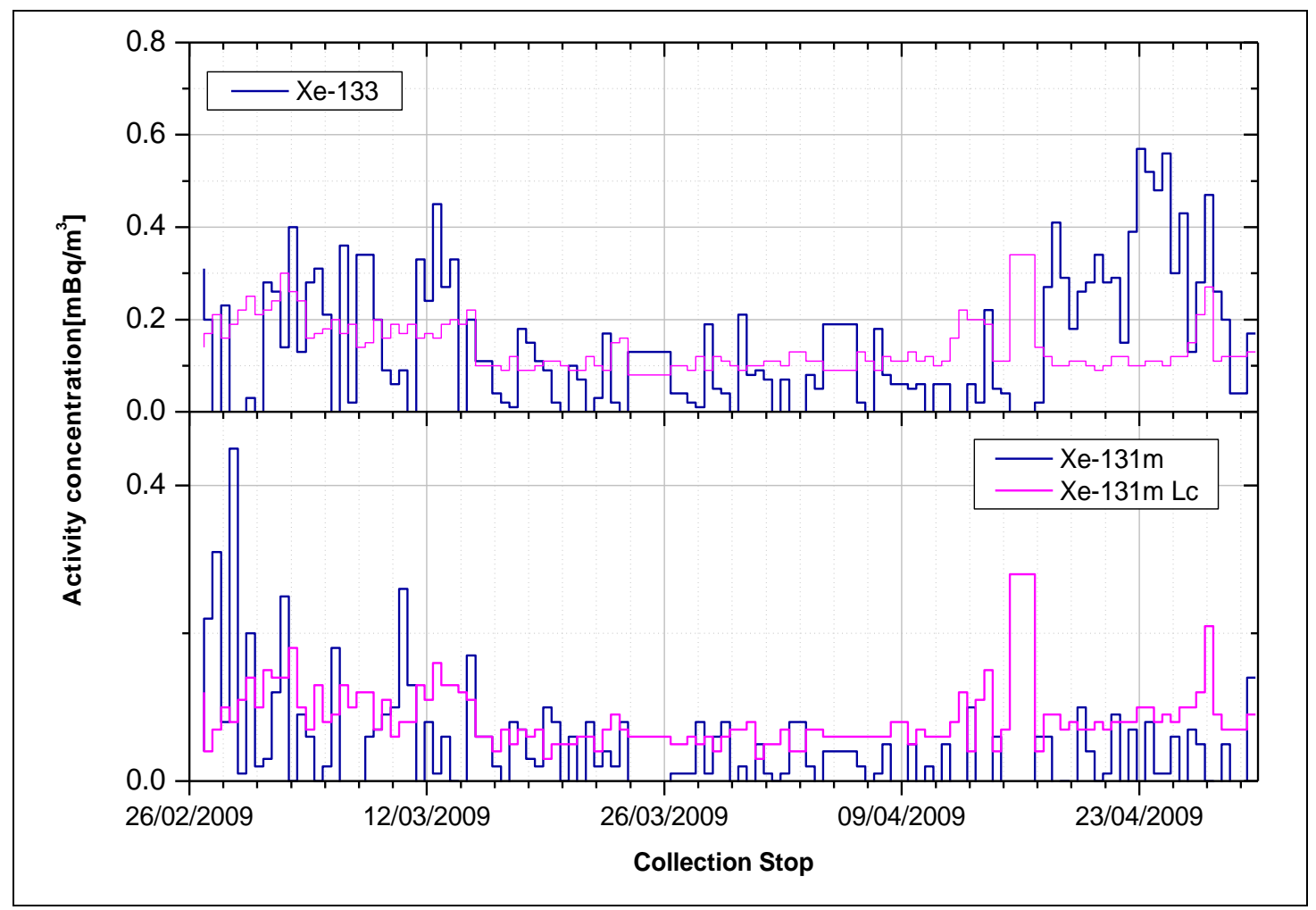

Figure 2.31. Time Series of the Radioxenon Isotopes $131 \mathrm{~m}$ and 133 .

A simple statistical analysis of the obtained concentrations is presented in Table 2.5. The results are obtained on a subset of the total data set, where small stable xenon volumes and acquisition times have been filtered away. Furthermore, samples with very high radon contents also have been removed.

Table 2.5. Statistical Overview of the Results

\begin{tabular}{ccccc}
\hline $\mathrm{mBq} / \mathrm{m}^{3}$ & ${ }^{131 \mathrm{~m}} \mathrm{Xe}$ & ${ }^{133 \mathrm{~m}} \mathrm{Xe}$ & ${ }^{133} \mathrm{Xe}$ & ${ }^{135} \mathrm{Xe}$ \\
\hline Minimum concentration & -0.11 & -0.11 & -0.15 & -1.06 \\
Maximum concentration & 0.41 & 0.18 & 0.57 & 1.24 \\
Median concentration & 0.02 & 0.00 & 0.09 & 0.10 \\
Mean concentration & 0.04 & 0.00 & 0.14 & 0.13 \\
95th percentile & 0.18 & 0.08 & 0.41 & 0.66 \\
\hline
\end{tabular}

As can be seen in Figure $2.32,{ }^{133} \mathrm{Xe}$ and ${ }^{131 \mathrm{~m}} \mathrm{Xe}$ appear to be anti-correlated as in other locations. In 46 samples, ${ }^{133} \mathrm{Xe}$ is present (i.e., value is larger than $\mathrm{L}_{\mathrm{c}}$ ) but there is no ${ }^{131 \mathrm{~m}} \mathrm{Xe}$; in 22 samples, ${ }^{131 \mathrm{~m}} \mathrm{Xe}$ is present but there is no ${ }^{133} \mathrm{Xe}$; and both nuclides are present in only five samples. This indicates that ${ }^{133} \mathrm{Xe}$ and ${ }^{131 \mathrm{~m}} \mathrm{Xe}$ most probably originate from different sources. 


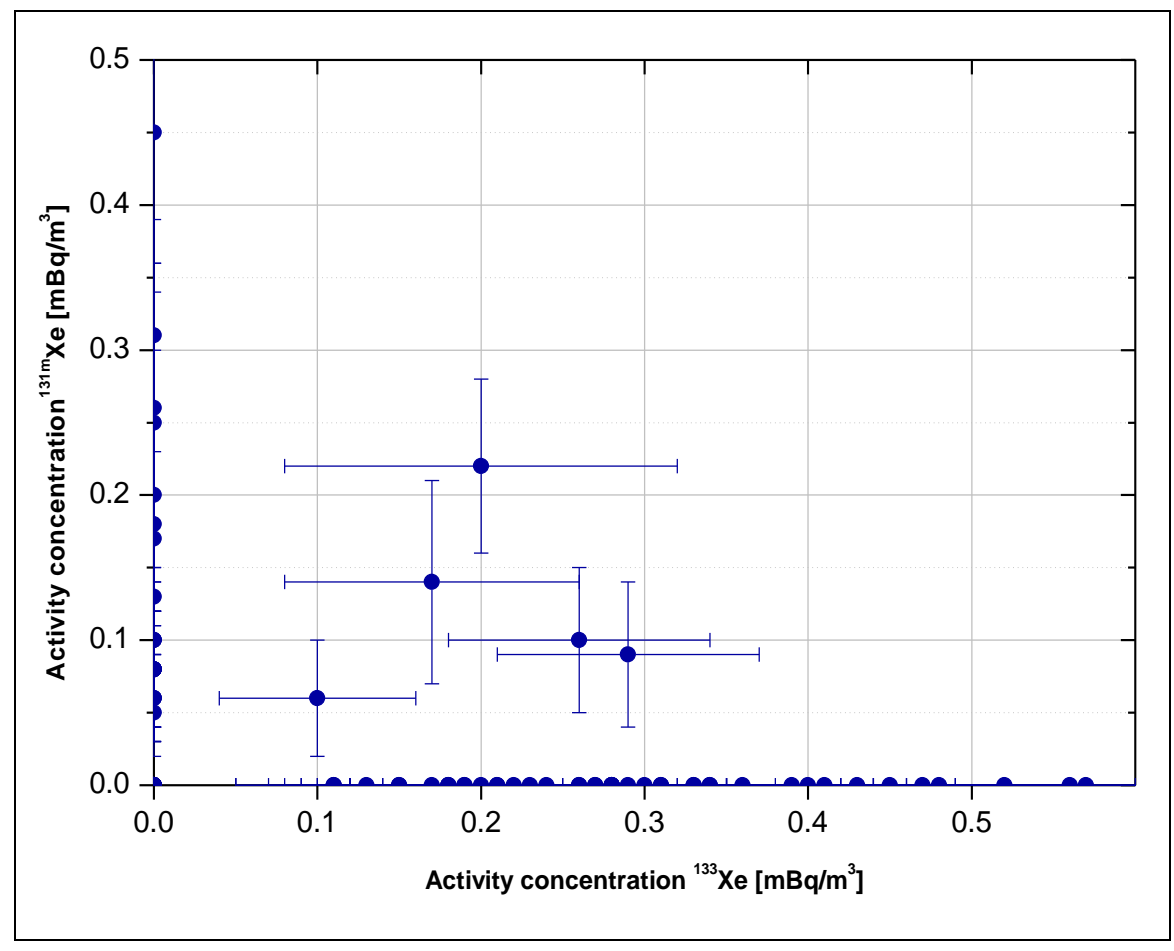

Figure 2.32. Correlation Between ${ }^{133} \mathrm{Xe}$ and ${ }^{131 \mathrm{~m}} \mathrm{Xe}$.

Before the campaign was initiated, atmospheric network forecast calculations (PSR) for 10 days were performed using 2007 March, April, and May meteorological data (Figure 2.27). After the campaign, the same calculations were performed for a 21-day period (Figure 2.28). 


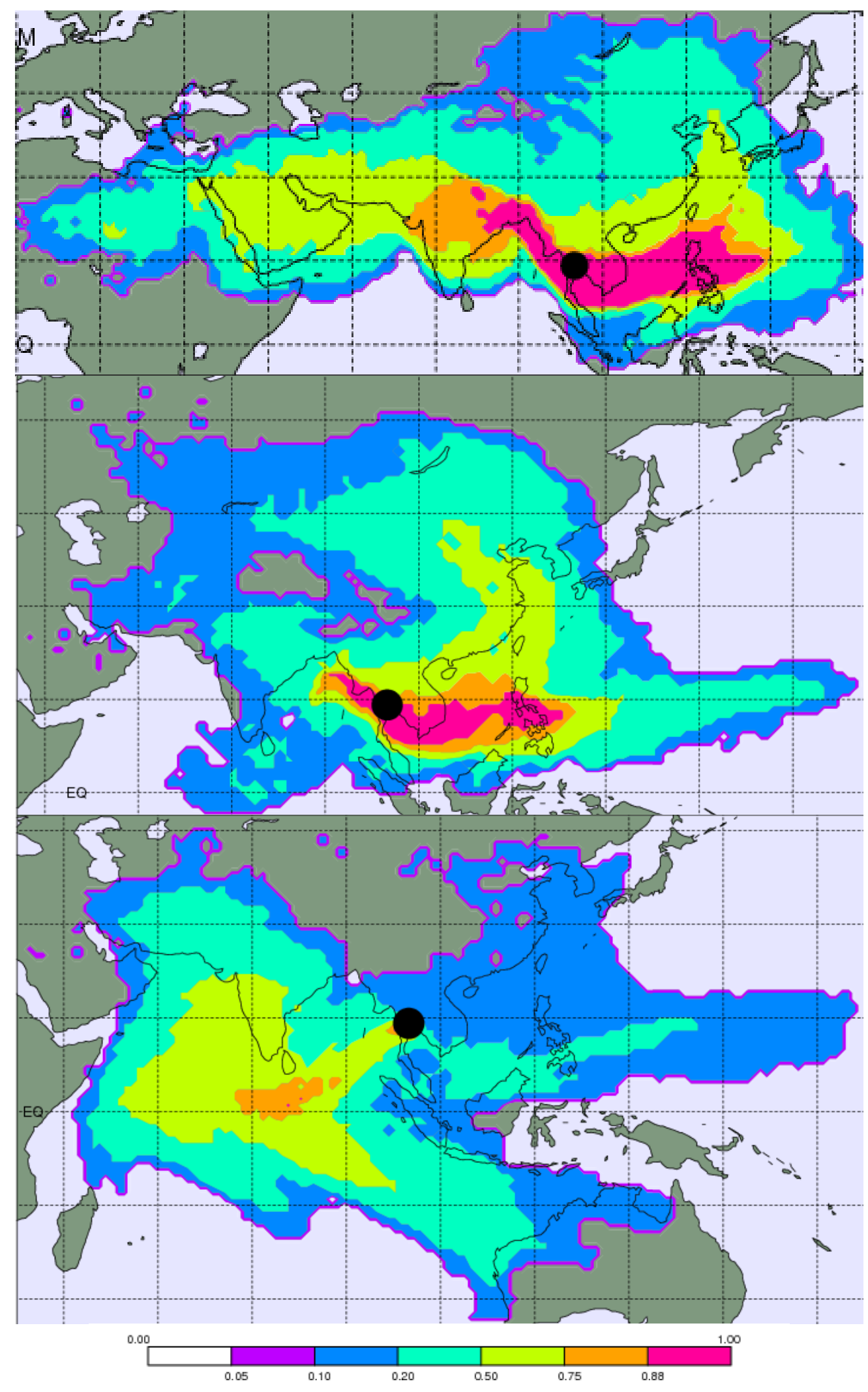

Figure 2.33. Projected Network Coverage for the Chiang Mai Station (black spot) with (from top to bottom) March, April, and May 2007 SRS fields (the scale indicates the PSR correlation) 


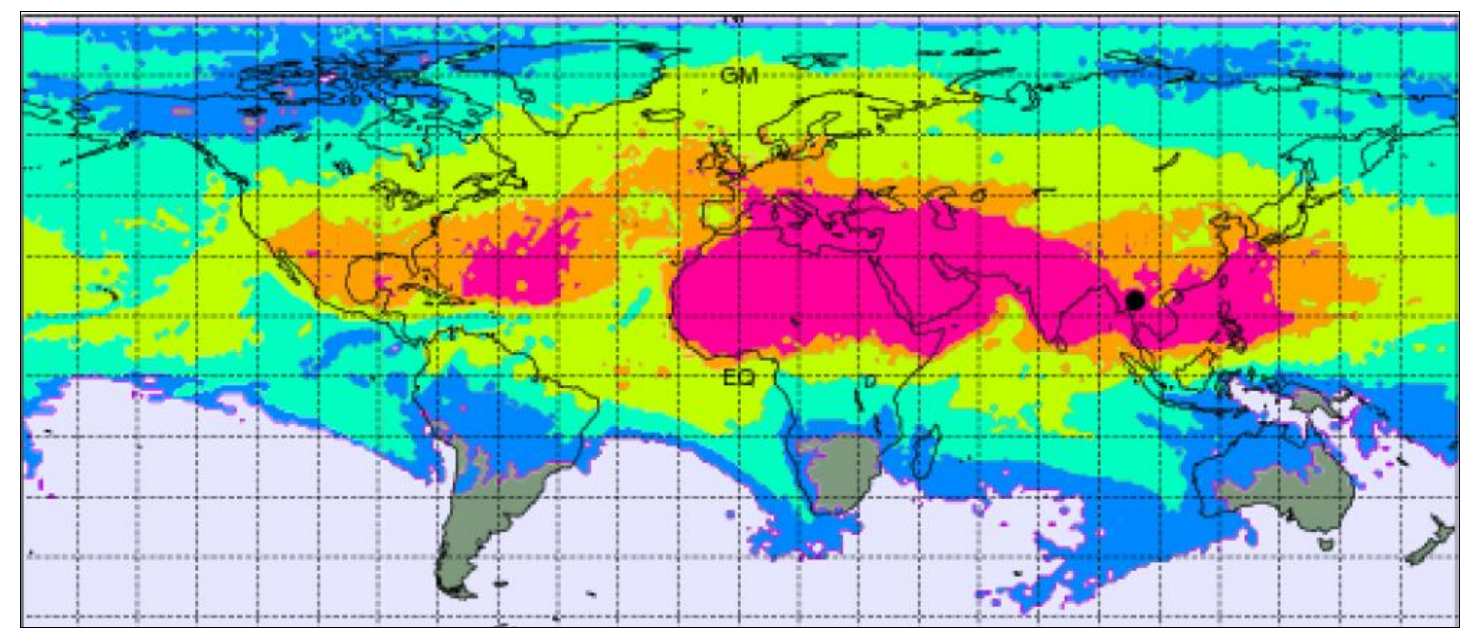

Figure 2.34. Actually Encountered Network Coverage for Chiang Mai with SRS Data Pertaining to Measurements

The highest detection of ${ }^{133} \mathrm{Xe}$ measured in Chiang Mai was $0.57 \mathrm{mBq} / \mathrm{m}^{3}$. Sample collection stopped on April 23 at 03:00 UTC. Identifying a possible source region, using the calculated field of regard for that measurement, shows a possible release from the nuclear power plant of Rahjastan (India) around April 19 or another Indian nuclear power plant (NPP) (Figure 2.35). However, the signal was so weak and singular that there is no chance to discriminate one NPP from the other.

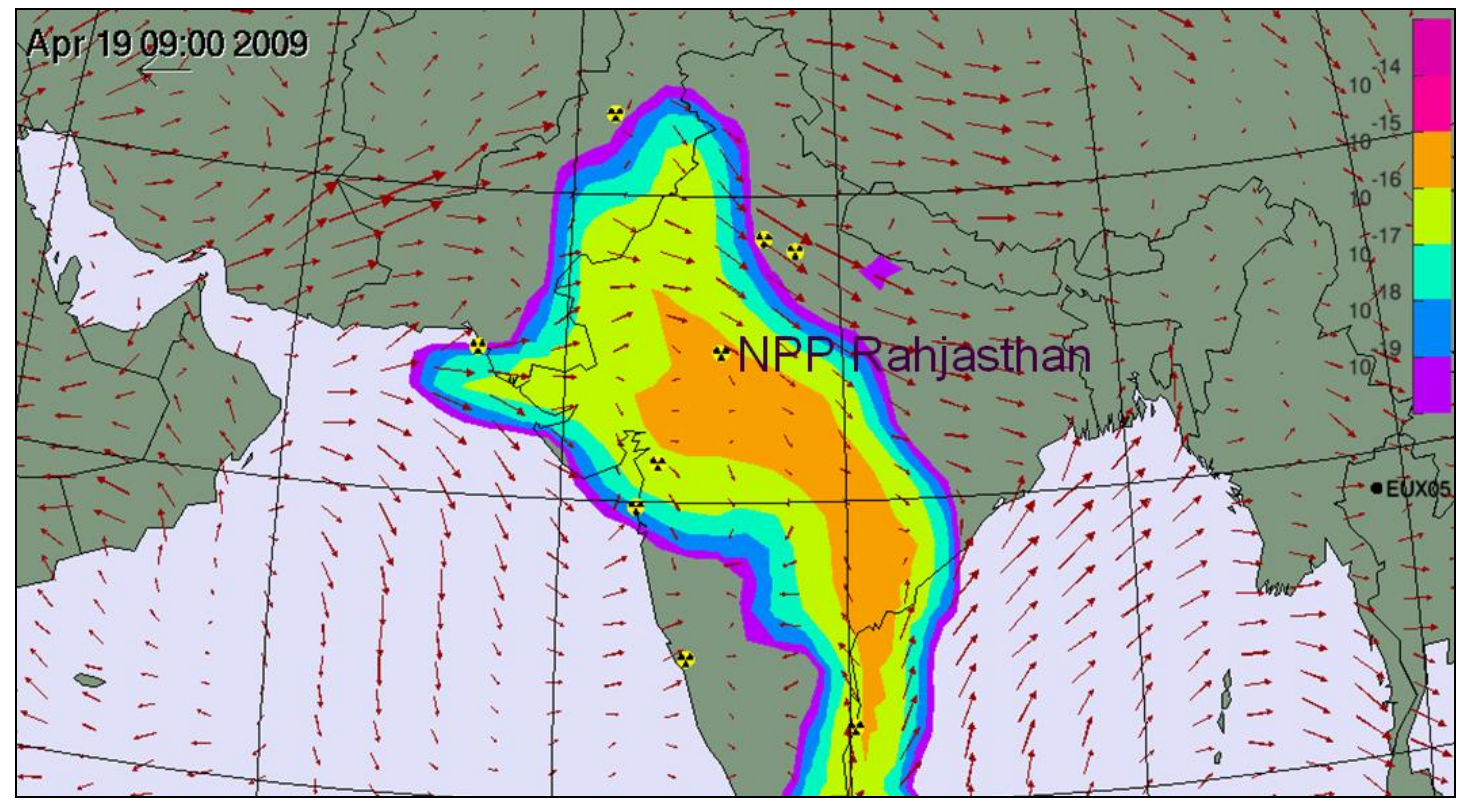

Figure 2.35. Backtracking example for the Chiang Mai (EUX05) Measurement of April 23 at 03:00 UTC. 


\subsubsection{Conclusion for the Thai Campaign}

Radioxenon measurements were performed between February 26 and April 29, 2009 at Chiang Mai University, Thailand. The measurement results show clear indications of radioxenon, although on a low level: a maximum of 0.57 of ${ }^{133} \mathrm{Xe} \mathrm{mBq} / \mathrm{m}^{3}$ and a maximum of 0.41 of ${ }^{133} \mathrm{Xe} \mathrm{mBq} / \mathrm{m}^{3}$ were measured during the campaign.

Meteorological backtracking of the air mass shows that the wind during the measurement period came mainly from the southwest indicating possible ${ }^{133}$ Xe sources in India, even from as far away as the NPP located northwest of India and possibly from ${ }^{131 \mathrm{~m}}$ Xe sources in neighboring Myanmar.

The fact that Chang Mai exhibits such low concentrations is significant. The conditions for radioxenon measurements were not known before these measurements and since little in known about local sources, these measurements were important to make.

\subsection{The Measurements in Germany}

\subsubsection{Site Survey}

On February 12-15, 2008, the Neckarwestheim NPP was visited and surveyed as a potential site for the measurements in Germany. However, the plant owner, EnBW, eventually decided not to cooperate. Contacts via the BfS made it possible for a field campaign to take place after a fuel element was damaged at the Isar-I NPP. It is a boiling-water reactor with a thermal power of $878 \mathrm{MW}$ that was commissioned in 1977.

\subsubsection{Local Partner}

The local partner was E.ON, Isar NPP.

\subsubsection{Site Preparations}

No technical preparations were done in Germany as FOI brought and used their mobile sampling equipment, which was mounted on a truck.

\subsubsection{Deployment and Operation of the Mobile Radioxenon System}

On January 19, 2009, E.ON proposed measurements at Isar-I during a scheduled revision after 18 months of operation. On March 2, the FOI team arrived with a truck with the mobile SAUNA sampler. On March 4 and 5, four background samples were taken. On March 6, there was a very small pre-release of $160 \mathrm{MBq}$ between 16:00 - 18:00 h. The full release started on March 7 at 8:00 h and ended on March 8 at 3:00h (all times CET). The team went sampling according to meteorological forecasts made by the BfS. 


\subsubsection{Overview of Results}

The goal of this campaign was to assess the direct impact of NPPs on radioxenon background, capture the exceptional event of a reactor shutdown with direct releases bypassing the charcoal decay assembly, and compare stack measurements with nearby environmental measurements.

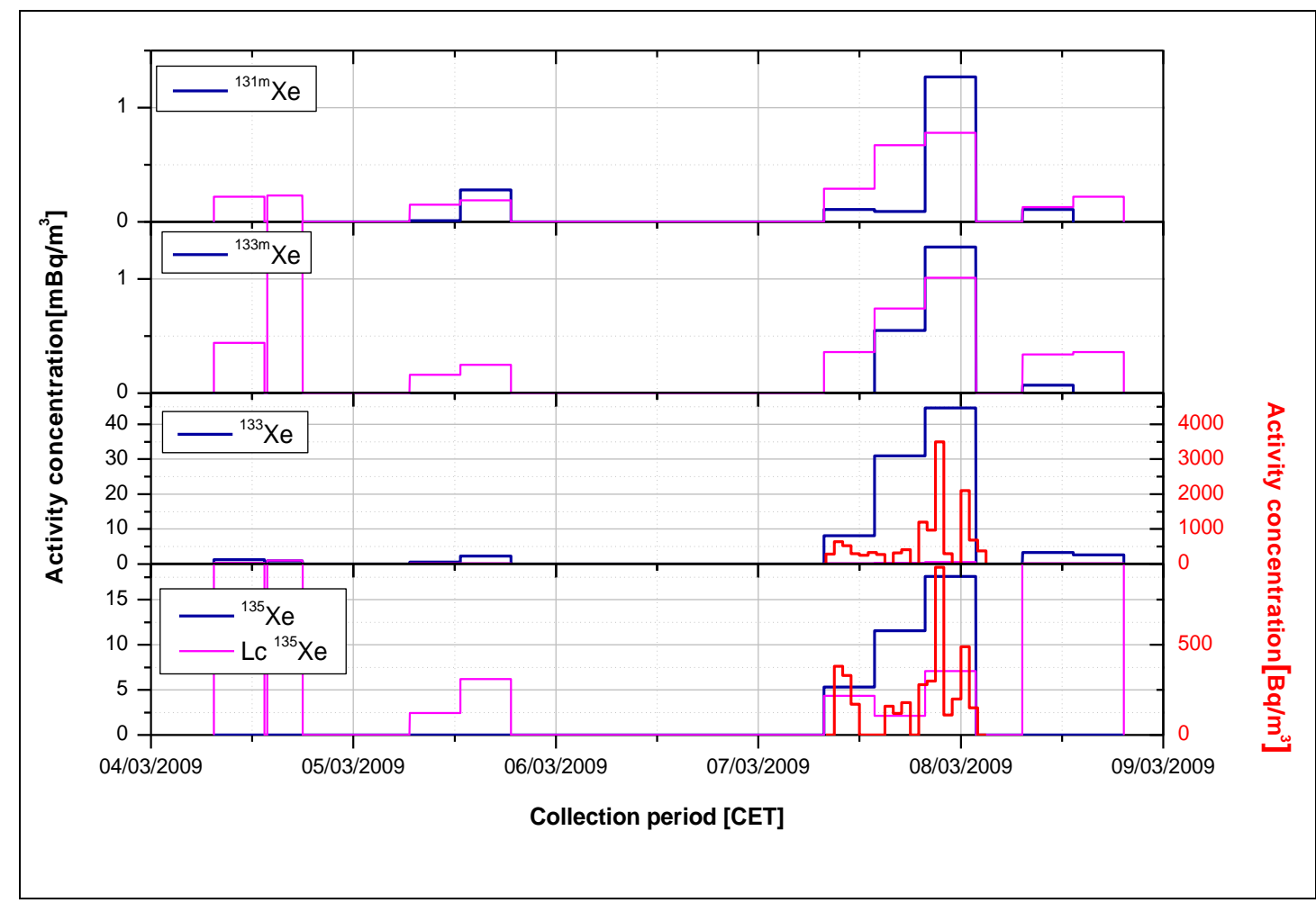

Figure 2.36. Activity Concentration of the Relevant Radioxenon Isotopes. Values shown in blue are environmental samples. The red line shows the activity concentration measured in the stack.

The two four-isotopic measurements match the isotopic ratios of civil sources, i.e., they are in the ratio graph situated near the steady-state equilibrium point for a Boiling Water Reactor (BWR) (Figure 2.37). 


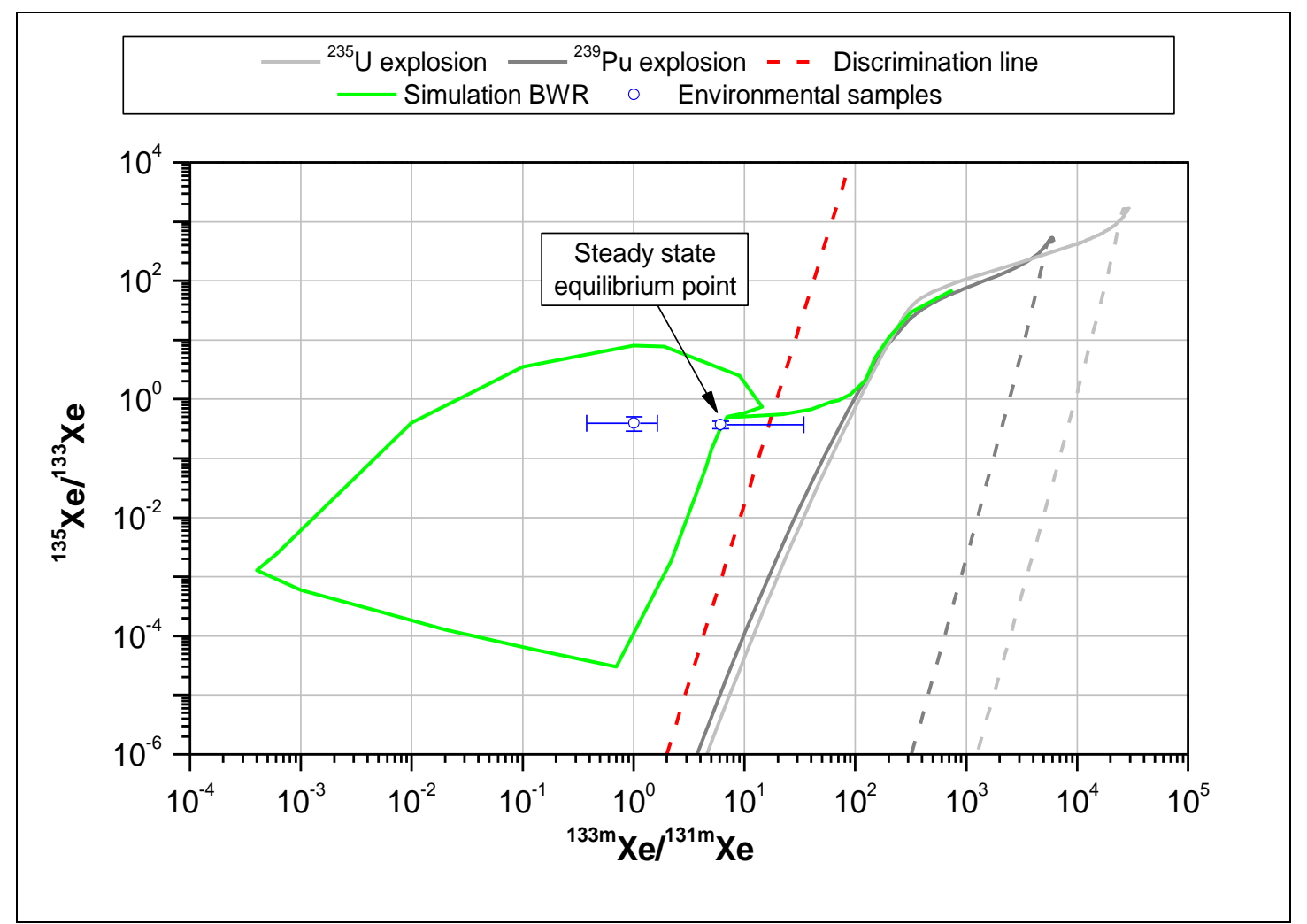

Figure 2.37. Four-Isotopic Graph Indicating the Measurements (Blue), a Reactor Cycle (Green), the Discrimination Line (Red), and Two Types of Nuclear Explosions (Grey)

The isotopic ratios ${ }^{135} \mathrm{Xe} /{ }^{133} \mathrm{Xe}$ from the stack, measured in-situ with a gamma detector, matches well with the field measurements (beta-gamma). The activities of the ${ }^{131 \mathrm{~m}} \mathrm{Xe}$ and ${ }^{133 \mathrm{~m}} \mathrm{Xe}$ isomeres measured in the NPP stack were below their detection limit.

\subsection{Further Site Surveys}

Two other site surveys were conducted at other sites to determine exact locations, check infrastructures, and establish contacts with local partners for the measurements. The originally planned sites in Oman and Nepal were visited, and close contacts were established with local partners for each site, but no campaign took place.

\subsubsection{Site Survey in Oman}

In Oman, the site survey was done March 2-5, 2008 at the Earthquake Monitoring Center (EMC) of Sultan Qaboos University campus. Potential sites in the campus were the EMC or the Agricultural Department buildings. An alternative site for the measurement, which was also visited, was the building of the Meteorological Department at the Muscat International Airport.

In the end, the partner in Oman could not provide an appropriate room for the measurements in due time. A further delay of the planned measurements in Oman was not justifiable because this would have had a serious negative impact on the overall planning. Consequently, the obligations to perform 
measurements in Oman were replaced by the obligation to perform measurements in Kuwait for an extended period of 47 days that was assessed as equivalent in terms of cost and effort. From a scientific point of view, the change from two points to one point and doubling the period had an equal value.

\subsubsection{Site Survey in Nepal}

In Nepal, the site visit was conducted between June 21 and July 3, 2008 in cooperation with several governmental institutions: Nepal Academy of Science and Technology (NAST), Tribhuvan University, Central Department of Physics Department of Mining and Geology, and the Department of Hydrology and Meteorology. It was agreed that the measurements would be done at the Tribhuvan University for a period of six weeks, from January to February 2009.

The site conditions in Nepal were found to be much more difficult than at other sites. The infrastructure at the Tribhuvan University campus needed a special upgrade. Regular, long power outages made it necessary to have an electrical generator sufficient to run the SAUNA system, and the air conditioning needed to be upgraded. Some upgrades with the room were also found to be necessary in addition to special security provisions. In addition, costs for shipping He carrier gas to the site in Nepal were incredibly high, since we understood that gases were shipped from India to this location.

The visit in Nepal established cooperation links with the Nepal government and raised awareness of the CTBT in Nepal. However, an exchange of letters for cooperation, as well as the procurement for the potential upgrade of the measurement room took many months and in the end could not be concluded within the set time frame. Consequently, the obligations to perform measurements in Nepal were replaced by the obligation to perform a longer period of measurements in Thailand. From a scientific point of view, the change from two points to one point and doubling the period had an equal value. 



\subsection{Overall Conclusions}

Analyses of the performed radioxenon measurement campaign data indicate that knowledge about releases from RPF in Belgium (Fleurus) and South Africa (Pelindaba), two of the four largest RPFs worldwide, is considerably improved. Together with first measurements of remote areas (Kuwait and Thailand), this project provided valuable progress towards completing a global radioxenon inventory to fill the gaps in areas where no data were yet available.

The findings corroborate the hypothesis that a few major radioxenon sources contribute in great part to the global radioxenon background. A more specific knowledge of source characteristics will be helpful to improve the capabilities of the IMS to distinguish these civil sources from treaty-relevant detections. A reduction of emissions by a factor of 1000 is technically possible for several of these known RPFs and would bring the releases to the same level as nuclear power plants $\left(\sim 10^{9} \mathrm{~Bq} /\right.$ day $)$. The benefits of such reductions should be communicated accordingly to the radiopharmaceutical-producing community, especially considering that future medical isotope production is predicted to increase, and mitigation drives the need to understand the chemical processes that allow releases.

However, our results at the IRE facility indicate that the xenon emissions from medical isotope production are currently not possible to rely on for all cases. While it should be possible to understand these measurements from the theoretical perspective to at least a factor of $10 \%$, as seen from data from the NTP plant in South Africa, the predictions and measurements of xenon isotopic ratios are significantly different at the IRE plant. In order to fully understand why this is occurring, more information is necessary and all of the release mechanisms at the plants need to be understood and likely measured at the source. This will be necessary to improve our capability to discriminate RFPs from nuclear explosions.

A recent workshop (WOSMIP 2009; http://wosmip.pnl.gov) has improved communications between the radiopharmaceutical producing community and the monitoring community, which found its roots in the project described here.

Another finding was the discovery of relevant independent sources of ${ }^{131 \mathrm{~m}} \mathrm{Xe}$ (the daughter of ${ }^{131} \mathrm{I}$ ), which has some potential to mask the isotopic signature of signals from nuclear explosions. As a consequence, there is some need to investigate local potential sources in the area of medical applications of ${ }^{131} \mathrm{I}$.

From a logistical and human resources point of view, the campaign was difficult and put strain and stress on the teams and the equipment. Problems occurred, e.g., with shipping equipment through customs. Particularly difficult was the transport from one measurement site to the next. The success and timeliness very much depended on the quality of the transport company. Further, there were specific problems caused by the radioactive sources. Minimizing the needs for these calibration sources would be an improvement. In order to minimize logistical concerns in the future, PNNL has designed a "Transportable Xenon Laboratory" (TXL) that can house a SAUNA system in a cargo container and provide for the interface for electrical and other requirements for the system so that upgrades to underequipped facilities are lessened. Logistics and sampling strategies for the RPF field measurements have much in parallel with a CTBT OSI, and the equipment used for such campaigns may also be used for OSI purposes and the TXL system concept could be used in an OSI. 
The project revealed many important findings on environmental radioxenon, which have been highlighted before. However, the campaigns were too short to fully reveal the seasonal influences and to fully understand phenomena like temporal decoupling, where due to inversions or stagnation local sampled air is decoupled from regional air possibly bearing radioxenon from distant sources. It is recommended, therefore, that such campaigns be continued to gain longer time series of environmental radioxenon. 


\subsection{Overview of Papers, Presentations, and Posters}

The following list gives an overview of presentations and other publications that originated out of the EU/JA-II project, as of July 2009.

Table 4.1. EU/JA-II project Presentations and Publications

\begin{tabular}{|c|c|c|c|}
\hline Author(s) & Title & Type & Where \\
\hline Becker A. & $\begin{array}{l}\text { PTS atmospheric transport } \\
\text { support in Belgium, South } \\
\text { Africa and Germany }\end{array}$ & Presentation & $\begin{array}{l}\text { EU-JA II: Noble Gas } \\
\text { Background Measurements } \\
\text { Workshop, 8-9 June 2009, } \\
\text { Vienna, Austria }\end{array}$ \\
\hline Becker A. & $\begin{array}{l}\text { PTS atmospheric transport } \\
\text { support in Kuwait and } \\
\text { Thailand }\end{array}$ & Presentation & $\begin{array}{l}\text { EU-JA II: Noble Gas } \\
\text { Background Measurements } \\
\text { Workshop, 8-9 June 2009, } \\
\text { Vienna, Austria }\end{array}$ \\
\hline $\begin{array}{l}\text { Camps J. and K. van der } \\
\text { Meer }\end{array}$ & $\begin{array}{l}\text { Local atmospheric transport } \\
\text { and dispersion calculations } \\
\text { during the radioxenon } \\
\text { measurement campaign in } \\
\text { Belgium }\end{array}$ & Presentation & $\begin{array}{l}\text { EU-JA II: Noble Gas } \\
\text { Background Measurements } \\
\text { Workshop, 8-9 June 2009, } \\
\text { Vienna, Austria }\end{array}$ \\
\hline $\begin{array}{l}\text { Peterson J., P. Andersson, L- } \\
\text { E De Geer, K. Elmgren, K. } \\
\text { Lindh, A. Ringbom, C. } \\
\text { Söderström }\end{array}$ & $\begin{array}{l}\text { Kuwait \& Thailand } \\
\text { campaigns: Experience } \\
\text { gained }\end{array}$ & Presentation & $\begin{array}{l}\text { EU-JA II: Noble Gas } \\
\text { Background Measurements } \\
\text { Workshop, 8-9 June 2009, } \\
\text { Vienna, Austria }\end{array}$ \\
\hline $\begin{array}{l}\text { Ringbom A., P.R.J. Saey, P. } \\
\text { Andersson, S. Ban, A. } \\
\text { Becker, K. Elmgren, J. } \\
\text { Camps, L.-E. De Geer, K. } \\
\text { Lindh, N. Paquet, J. } \\
\text { Peterson, C. Söderström, M. } \\
\text { Sonck, T. Taffary, K. van der } \\
\text { Meer, B. Verboomen and M. } \\
\text { Zähringer }\end{array}$ & $\begin{array}{l}\text { Environmental } \\
\text { characterization of a major } \\
\text { radioxenon source in Europe }\end{array}$ & Poster & $\begin{array}{l}\text { International Scientific } \\
\text { Symposium, 10-12 June 2009, } \\
\text { Vienna, Austria }\end{array}$ \\
\hline $\begin{array}{l}\text { Ringbom A., P.R.J. Saey, T. } \\
\text { Bowyer, P. Andersson, M. } \\
\text { Aldener, D. Al Ajmi, M. S. } \\
\text { Al-Rashidi, A. Becker, E.-G. } \\
\text { Brunke, M.W. Cooper, L.-E. } \\
\text { De Geer, K. Elmgren, A. } \\
\text { Faanhof, J.C. Hayes, B. } \\
\text { Hosticka, C. Labuschagne, } \\
\text { L.S. Lidey, H. van der Linde, } \\
\text { K. Lindh, N. Mumba, R.F. } \\
\text { Payne, J. Peterson, M. } \\
\text { Shalash, C. Söderström, R.C. } \\
\text { Thompson, U. Tippawan, N. } \\
\text { Wilson and M. Zähringer }\end{array}$ & $\begin{array}{l}\text { Measurements of the } \\
\text { atmospheric radioxenon } \\
\text { background at four locations } \\
\text { in Asia and Africa }\end{array}$ & Poster & $\begin{array}{l}\text { International Scientific } \\
\text { Symposium, 10-12 June 2009, } \\
\text { Vienna, Austria }\end{array}$ \\
\hline
\end{tabular}


Table 4.1. (contd)

\begin{tabular}{|c|c|c|c|}
\hline Author(s) & Title & Type & Where \\
\hline Saey P.R.J. & $\begin{array}{l}\text { Isotopic Analysis of the } \\
\text { Belgian field Campaign }\end{array}$ & Presentation & $\begin{array}{l}\text { EU-JA II: Noble Gas } \\
\text { Background Measurements } \\
\text { Workshop, 8-9 June 2009, } \\
\text { Vienna, Austria }\end{array}$ \\
\hline $\begin{array}{l}\text { Saey P.R.J., A. Ringbom, A. } \\
\text { Becker, J. Camps, N. Paquet, } \\
\text { M. Sonck, T. Taffary, K. van } \\
\text { der Meer, B. Verboomen, M. } \\
\text { Zähringer, P. Andersson, S. } \\
\text { Ban, K. Elmgren, L.-E. De } \\
\text { Geer, K. Lindh, J. Peterson } \\
\text { and C. Söderström }\end{array}$ & $\begin{array}{l}\text { Environmental } \\
\text { characterisation of a major } \\
\text { radioxenon source in Europe }\end{array}$ & Poster & $\begin{array}{l}\text { Geophysical Research } \\
\text { Abstracts, EGU2009-9182 }\end{array}$ \\
\hline $\begin{array}{l}\text { Saey P.R.J., A. Ringbom, D. } \\
\text { Al-Ajmi, M. Al-Rashidi, M. } \\
\text { Al-Sudairawi, P. Andersson, } \\
\text { A. Becker, T. Bowyer, M.W. } \\
\text { Cooper, L.-E. De Geer, K. } \\
\text { Elmgren, R. Hansen, J.C. } \\
\text { Hayes, B. Hosticka, R. } \\
\text { Kirkham, L. Lidey, K. } \\
\text { Lindh, J. McIntyre, H. } \\
\text { Miley, J. Peterson, R. } \\
\text { Plenteda, C. Söderström, M. } \\
\text { Shalash, R.C. Thompson, R. } \\
\text { Williams and M. Zähringer }\end{array}$ & $\begin{array}{l}\text { Environmental radioxenon } \\
\text { measurements in Kuwait City }\end{array}$ & Presentation & $\begin{array}{l}\text { EU-JA II: Noble Gas } \\
\text { Background Measurements } \\
\text { Workshop, 8-9 June 2009, } \\
\text { Vienna, Austria }\end{array}$ \\
\hline $\begin{array}{l}\text { Saey P.R.J., A. Ringbom, } \\
\text { T.W. Bowyer, A. Becker, L.- } \\
\text { E. De Geer, M. Nikkinen, } \\
\text { and R.F. Payne }\end{array}$ & $\begin{array}{l}\text { Understanding radioxenon } \\
\text { isotopic ratios originating } \\
\text { from radiopharmaceutical } \\
\text { facilities }\end{array}$ & Presentation & $\begin{array}{l}\text { Geophysical Research } \\
\text { Abstracts, EGU2009-9749 }\end{array}$ \\
\hline $\begin{array}{l}\text { Saey P.R.J., T. Bowyer, A. } \\
\text { Becker, E.-G. Brunke, G. } \\
\text { Coetzee, M.W. Cooper, K. } \\
\text { Elmgren, D. Haas, R. } \\
\text { Hansen, J.C. Hayes, B. } \\
\text { Hosticka, R. Kirkham, C. } \\
\text { Labuschagne, L. Lidey, J. } \\
\text { McIntyre, H.S. Miley, B.A. } \\
\text { Parker, A. Ringbom, R.C. } \\
\text { Thompson, R. Williams, N. } \\
\text { Wilson and M. Zähringer }\end{array}$ & $\begin{array}{l}\text { Radioxenon measurements at } \\
\text { the Global Atmospheric } \\
\text { Watch Station, Cape Point, } \\
\text { South Africa }\end{array}$ & Presentation & $\begin{array}{l}\text { EU-JA II: Noble Gas } \\
\text { Background Measurements } \\
\text { Workshop, 8-9 June 2009, } \\
\text { Vienna, Austria }\end{array}$ \\
\hline $\begin{array}{l}\text { Saey P.R.J., T. Bowyer, A. } \\
\text { Ringbom }\end{array}$ & $\begin{array}{l}\text { Isotopic noble gas signatures } \\
\text { released from } \\
\text { radiopharmaceutical } \\
\text { production facilities - } \\
\text { simulations compared to } \\
\text { measurements }\end{array}$ & Paper & $\begin{array}{l}\text { Journal of Environmental } \\
\text { Radioactivity, to be submitted }\end{array}$ \\
\hline
\end{tabular}


Table 4.1. (contd)

\begin{tabular}{|c|c|c|c|}
\hline Author(s) & Title & Type & Where \\
\hline $\begin{array}{l}\text { Saey P.R.J., T. Bowyer, A. } \\
\text { Ringbom, M. Zähringer }\end{array}$ & $\begin{array}{l}\text { European Union / Joint Action } \\
\text { II: Noble Gas Background } \\
\text { Measurements }\end{array}$ & Presentation & $\begin{array}{l}\text { EU-JA II: Noble Gas } \\
\text { Background Measurements } \\
\text { Workshop, 8-9 June 2009, } \\
\text { Vienna, Austria }\end{array}$ \\
\hline $\begin{array}{l}\text { Saey P.R.J., T. Bowyer, M. } \\
\text { Aldener, A. Becker, M.W. } \\
\text { Cooper, K. Elmgren, A. } \\
\text { Faanhof, J.C. Hayes, B. } \\
\text { Hosticka, L. Lidey, N. } \\
\text { Mumba, R. Payne, A. } \\
\text { Ringbom, R.C. Thompson, } \\
\text { H. van der Linde, G. } \\
\text { Wortmann and M. Zähringer }\end{array}$ & $\begin{array}{l}\text { Measurement and evaluation } \\
\text { of environmental radioxenon } \\
\text { signals from a singular large } \\
\text { source emitter in Africa }\end{array}$ & Presentation & $\begin{array}{l}\text { EU-JA II: Noble Gas } \\
\text { Background Measurements } \\
\text { Workshop, 8-9 June 2009, } \\
\text { Vienna, Austria }\end{array}$ \\
\hline $\begin{array}{l}\text { Saey P.R.J., T. Bowyer, M. } \\
\text { Aldener, A. Becker, M.W. } \\
\text { Cooper, K. Elmgren, A. } \\
\text { Faanhof, J.C. Hayes, B. } \\
\text { Hosticka, L. Lidey, N. } \\
\text { Mumba, R. Payne, A. } \\
\text { Ringbom, R.C. Thompson, } \\
\text { H. van der Linde, G. } \\
\text { Wortmann and M. Zähringer }\end{array}$ & $\begin{array}{l}\text { Evaluation of environmental } \\
\text { radioxenon signals from a } \\
\text { singular large source emitter in } \\
\text { Africa }\end{array}$ & Poster & $\begin{array}{l}\text { International Scientific } \\
\text { Symposium, 10-12 June 2009, } \\
\text { Vienna, Austria }\end{array}$ \\
\hline $\begin{array}{l}\text { Saey P.R.J., T.W. Bowyer, } \\
\text { M. Aldener, A. Becker, } \\
\text { M.W. Cooper, K. Elmgren, } \\
\text { A. Faanhof, J.C. Hayes, B. } \\
\text { Hosticka, L.S. Lidey, N. } \\
\text { Mumba, R.F. Payne, A. } \\
\text { Ringbom, R.C. Thompson, } \\
\text { H. van der Linde, G. } \\
\text { Wortmann and M. Zähringer }\end{array}$ & $\begin{array}{l}\text { Evaluation of environmental } \\
\text { radioxenon isotopic signals } \\
\text { from a singular large source } \\
\text { emitter }\end{array}$ & Poster & $\begin{array}{l}\text { Geophysical Research } \\
\text { Abstracts, EGU2009-9491 }\end{array}$ \\
\hline Thompson R.C. & $\begin{array}{l}\text { Worldwide SAUNA } \\
\text { Deployments - Lessons } \\
\text { Learned and Opportunities for } \\
\text { Improvement }\end{array}$ & Presentation & $\begin{array}{l}\text { EU-JA II: Noble Gas } \\
\text { Background Measurements } \\
\text { Workshop, 8-9 June 2009, } \\
\text { Vienna, Austria }\end{array}$ \\
\hline $\begin{array}{l}\text { Zähringer M., P.R.J. Saey, } \\
\text { M. Nikkinen, R. Werzi }\end{array}$ & $\begin{array}{l}\text { Result and discussion of the } \\
\text { Campaign in Germany at Isar- } \\
\text { I Nuclear Power Plant }\end{array}$ & Presentation & $\begin{array}{l}\text { EU-JA II: Noble Gas } \\
\text { Background Measurements } \\
\text { Workshop, 8-9 June 2009, } \\
\text { Vienna, Austria }\end{array}$ \\
\hline $\begin{array}{l}\text { Zähringer M., P.R.J. Saey, } \\
\text { M. Nikkinen, U. Tippawan, } \\
\text { S. Singkarat }\end{array}$ & $\begin{array}{l}\text { Result and discussion of the } \\
\text { Campaign in Chiang Mai, } \\
\text { Thailand }\end{array}$ & Presentation & $\begin{array}{l}\text { EU-JA II: Noble Gas } \\
\text { Background Measurements } \\
\text { Workshop, 8-9 June 2009, } \\
\text { Vienna, Austria }\end{array}$ \\
\hline
\end{tabular}




\subsection{References}

Auer, M., Axelsson, A., Blanchard, X., Bowyer, T.W., Brachet, G., Bulowski, I., Dubasov, Y., Elmgren, K., Fontaine, J.P., Harms, W., Hayes, J.C., Heimbigner, T.R., McIntyre, J.I., Panisko, M.E., Popov, Y., Ringbom, A., Sartorius, H., Schmid, S., Schulze, J., Schlosser, C., Taffary, T., Weiss, W. and Wernsperger, B. (2004). Intercomparison experiments of systems for the measurement of xenon radionuclides in the atmosphere. Applied Radiation and Isotopes, 60, 6, 863-877.

Ball, R.M. (1999). Characteristics of nuclear reactors used for the production of molybdenum-99. IAEATECDOC, 1065, 5-17.

Becker, A., Wotawa, G., Ringbom, A. and Saey, P.R.J. (2009). Backtracking of noble gas measurements taken in the aftermath of the announced October 2006 event in North Korea by means of PTS methods in nuclear source estimation and reconstruction. Pure and Applied Geophysics, accepted.

Becker, A., Wotawa, G., De Geer, L.-E., Seibert, P., Draxler, R.R., Sloan, C., D'Amours, R., Hort, M., Glaab, H., Heinrich, P., Grillon, Y., Shershakov, V., Katayama, K., Zhang, Y., Stewart, P., Hirtl, M., Jean, M. and Chen, P. (2007). Global backtracking of anthropogenic radionuclides by means of a receptor oriented ensemble dispersion modelling system in support of Nuclear-Test-Ban Treaty verification. Atmospheric Environment, 41, 21, 4520-4534.

Bonet, H., David, B. and Ponsard, B. (2005). Production of molybdenum-99 in Europe: status and perspectives. 9th International Topical Meeting on Research Reactor Fuel Management, Budapest, April 2005.

Bowyer, T.W., Schlosser, C., Abel, K.H., Auer, M., Hayes, J.C., Heimbigner, T.R., McIntyre, J.I., Panisko, M.E., Reeder, P.L., Satorius, H., Schulze, J. and Weiss, W. (2002). Detection and analysis of xenon isotopes for the comprehensive nuclear-test-ban treaty international monitoring system. Journal of Environmental Radioactivity, 59, 2, 139-151.

Dahlman, O., Mykkeltveit, S. and Haak, H. (2009). Nuclear Test Ban-Converting Political Visions to Reality. Heidelberg: Springer. 978-1-4020-6883-6

De Geer, L.-E. (1996). Atmospheric Radionuclide Monitoring: a Swedish Perspective. In Huseby, E.S. and Dainty, A.M., Monitoring a Comprehensive Nuclear Test Ban Treaty (pp. 157-177). The Netherlands: Kluwer Academic Publishers.

IAEA (1989). Fission Molybdenum for Medical Use. IAEA-TECDOC, 515, International Atomic Energy Agency, Vienna.

Kalinowski, M.B. and Pistner, C. (2006). Isotopic signature of atmospheric xenon released from light water reactors. Journal of Environmental Radioactivity, 88, 3, 215-235.

Kalinowski, M.B., Axelsson, A., Bean, M., Blanchard, X., Bowyer, T.W., Brachet, G., McIntyre, J.I., Peters, J., Pistner, C., Raith, M., Ringbom, A., Saey, P.R.J., Schlosser, C., Stocki, T.J., Taffary, T. and Ungar, R.K. (2009). Discrimination of nuclear explosions against civilian sources based on atmospheric xenon isotopic activity ratios. Pure and Applied Geophysics, submitted. 
Le Roux, J.S. (1991). Die produksie en kwaliteitskontrole van tegnesium-99m kitsstelle met spesiale verwysing na 'n kistsstel vir rooiselmerking. In Medicine (pp. 77). Stellenbosch, Rep. of South Africa: Universiteit van Stellenbosch.

Ringbom, A., Larson, T., Axelsson, A., Elmgren, K. and Johansson, C. (2003). SAUNA--a system for automatic sampling, processing, and analysis of radioactive xenon. Nuclear Instruments and Methods in Physics Research Section A: Accelerators, Spectrometers, Detectors and Associated Equipment, 508, 3 , 542-553.

Saey, P.R.J. (2009). The Influence of Radiopharmaceutical Isotope Production on the Global Radioxenon Background. Journal of Environmental Radioactivity, 100, 5, 396-406.

Saey, P.R.J., Bean, M., Becker, A., Coyne, J., d'Amours, R., Geer, L.-E.D., Hogue, R., Stocki, T.J., Ungar, R.K. and Wotawa, G. (2007). A long distance measurement of radioxenon in Yellowknife, Canada, in late October 2006. Geophys. Res. Lett.

Salacz, J. (1985). Reprocessing of irradiated uranium 235 for the production of Mo-99, I-131, Xe-133 radioisotopes. Revue IRE Tijdschrift, 9, 3, 22-28.

UNGA (1996). United Nations General Assembly Resolution Number 50/245 In U.N. New York, U.S.A.

Wotawa, G., De Geer, L.-E., Denier, P., Kalinowski, M., Toivonen, H., D'Amours, R., Desiato, F., Issartel, J.-P., Langer, M., Seibert, P., Frank, A., Sloan, C. and Yamazawa, H. (2003). Atmospheric transport modelling in support of CTBT verification--overview and basic concepts. Atmospheric Environment, 37, 18, 2529-2537. 


\section{Acknowledgments}

The project managers for this project were for CTBTO Paul Saey (Belgian, Kuwait, Mafikeng and Cape Point campaigns) and Matthias Zähringer (Thai and German campaign), for FOI Anders Ringbom and for PNNL Ted Bowyer.

Andreas Becker (CTBTO) provided before each campaign a detailed weather situation analysis, during the campaigns daily weather forecasts, fields of regard, and after the campaigns atmospheric transport analysis and interpretations.

We would like to thank Paul Saey, one of the authors listed on this paper, who contributed a large amount the analyses and writing of this document.

The campaigns were all successfully concluded due to the dedicated work of the following colleagues:

\begin{tabular}{|c|c|c|}
\hline Campaign & Institute & Staff \\
\hline \multirow[t]{5}{*}{ Belgium } & СТBTO & P.R.J. Saey \\
\hline & FANC & M. Sonck \\
\hline & FOI & $\begin{array}{l}\text { P. Andersson, S. Ban, L.-E. De Geer, K. Elmgren, K. Lindh, J. } \\
\text { Peterson. A. Ringbom and C. Söderström }\end{array}$ \\
\hline & IRE & N. Paquet and B. Verboomen \\
\hline & SCK-CEN & J. Camps, R. Carchon and K. van der Meer \\
\hline \multirow[t]{4}{*}{ Kuwait City } & СТВTO & R. Plenteda and P.R.J. Saey \\
\hline & FOI & $\begin{array}{l}\text { P. Andersson, L.-E. De Geer, K. Elmgren, K. Lindh, J. Peterson, A. } \\
\text { Ringbom, C. Söderström }\end{array}$ \\
\hline & KISR & D. Al-Ajmi, M.S. Al-Rashidi, M. Al-Saleh, M. Shalash \\
\hline & PNNL & $\begin{array}{l}\text { T. Bowyer, M.W. Cooper, R. Hansen, J.C. Hayes, B. Hosticka, R. } \\
\text { Kirkham, L. Lidey, J. McIntyre, H. Miley, R.C. Thompson and R. } \\
\text { Williams }\end{array}$ \\
\hline \multirow[t]{7}{*}{ Mafikeng } & CTBTO & P.R.J. Saey \\
\hline & FOI & K. Elmgren, A. Ringbom \\
\hline & GammaData & M. Aldener \\
\hline & NECSA & A. Faanhof \\
\hline & NTP & G. Wortmann \\
\hline & PNNL & $\begin{array}{l}\text { T. Bowyer, M.W. Cooper, J.C. Hayes, B. Hosticka, L. Lidey, R. } \\
\text { Payne and R.C. Thompson }\end{array}$ \\
\hline & U.o.M. & N. Mumba and H. van der Linde \\
\hline \multirow[t]{4}{*}{ Cape Point } & СТВTO & P.R.J. Saey and N. Wilson \\
\hline & FOI & K. Elmgren and A. Ringbom \\
\hline & PNNL & $\begin{array}{l}\text { T. Bowyer, M.W. Cooper, D. Haas, R. Hansen, J.C. Hayes, B. } \\
\text { Hosticka, R. Kirkham, L. Lidey, J. McIntyre, H.S. Miley, R.C. } \\
\text { Thompson and R. Williams }\end{array}$ \\
\hline & SAWS & E.-G. Brunke, G. Coetzee, C. Labuschagne and B.A. Parker \\
\hline \multirow[t]{4}{*}{ Chiang Mai } & СТBTO & M. Nikkinen, P.R.J. Saey and M. Zähringer \\
\hline & FNRF & S. Singkarat and U. Tippawan \\
\hline & FOI & $\begin{array}{l}\text { K. Elmgren, H. Henriksson, K. Lindh, J. Peterson, A. Ringbom, C. } \\
\text { Söderström and N. Tooloutalaie }\end{array}$ \\
\hline & PNNL & $\begin{array}{l}\text { T. Bowyer, J. Forrester, P. Keller, H.S. Miley, R. Kirkham, R.C. } \\
\text { Thompson and V. Woods }\end{array}$ \\
\hline Germany & BfS & $\begin{array}{l}\text { M. Auer, A. Deller, B. Gerich, C. Schlosser, R. Stapel, C. Strobl } \\
\text { and N. Zander }\end{array}$ \\
\hline
\end{tabular}


CTBTO

E.ON

FOI
S. Hebel, R. Werzi and M. Zähringer

J. Scheer and W. Schwarz

P. Andersson, K. Lindh, A. Ringbom and N. Tooloutalie 


\section{Distribution}

No. of

Copies

\# Name

Organization

Address

City, State and ZIP Code

\# Organization

Address

City, State and ZIP Code

Name

Name

Name

Name

Name (\#)

\# Name

Organization

Address

City, State and ZIP Code
No. of

\section{Copies}

\section{\# Foreign Distribution}

None

\# Local Distribution

Pacific Northwest National Laboratory

Name

Name

Name

Name

Name
Mailstop

Mailstop

Mailstop

Mailstop

(PDF) 


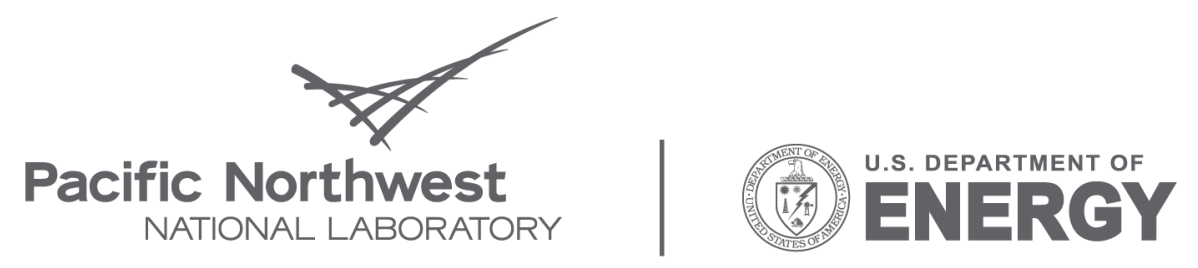

Proudly Operated by Battelle Since 1965

902 Battelle Boulevard

P.O. Box 999

Richland, WA 99352

1-888-375-PNNL (7665)

www.pnl.gov 